Questioning the SENIOR COHOUSING CHALLENGE:

A Cross-Sector Analysis of Interviews with Leading Experts

by

\title{
Lynn Pfeffer
}

A thesis submitted to the Faculty of Graduate and Postdoctoral Affairs in partial fulfillment of the requirements for the degree of

Master of Architectural Studies

Carleton University

Ottawa, Ontario

(C) 2018

Lynn Pfeffer 


\section{Abstract}

Seniors will make up an unprecedented $25 \%$ of Canadians by the year 2030. This demographic shift will challenge our society to address the basic human right of a dignified and healthy aging. One troubling aspect of aging is the degree to which seniors experience isolation and loneliness. Cohousing can offer older adults a place to age in place, within a 'community-of-care'. However, the challenges of creating senior cohousing are numerous - the failure rates staggering. What factors contribute to this challenge? What could the way forward look like? This thesis searches for answers in the perspectives of professionals representing sectors of the development process. Interviews were conducted with experts in: non-profit housing, housing policy, development consulting, and private real-estate. Focusing on urban senior cohousing in Ottawa, Convivium Cohousing is used as a case study to ground the theory. It is expected findings will transfer to other parts of Canada. 


\section{Acknowledgments}

With the deepest gratitude and respect, I thank my supervisor Federica Goffi for her unwavering support and encouragement. Your uncanny ability to know when to give feedback and when to listen is deeply appreciated.

To all those who participated so generously and willingly in the interviews for this thesis, I am indebted to you for your insights and expertise.

To Convivium Cohousing members, your perseverance and commitment have inspired me to continue on this challenging journey. Thank you for your patience while I turned my attention to this thesis work.

Gratitude to my dear friends for being there when I needed to rail, cry, or laugh; you know who you are.

To my dear Mother, for all the sacrifices you have made on my behalf, I am eternally grateful, and to all my other 'mothers' of this lifetime, thank you for your love.

This thesis is dedicated to all those in the future who may aspire to create a cohousing community. 


\section{Table of Contents}

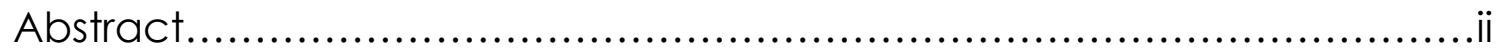

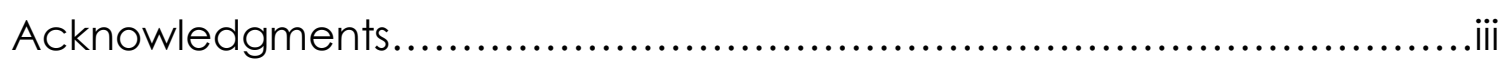

Table of Contents............................................................... iv

\section{Thesis Document:}

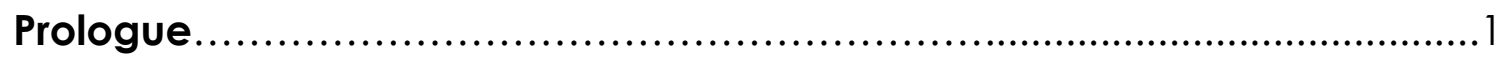

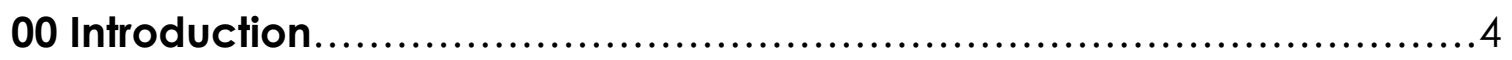

0.1 What is the Purpose of this Research? ........................................4

0.2 Why is this important to Canadian seniors and our society? ........5

0.3 What are the questions? ...............................................................

0.4 What methods are used for this research? ....................................

0.5 A Note on the contemporary nature of this thesis.........................

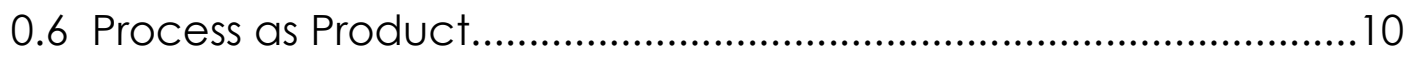

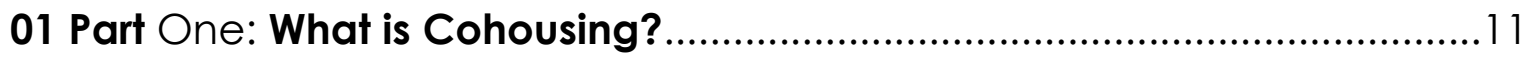

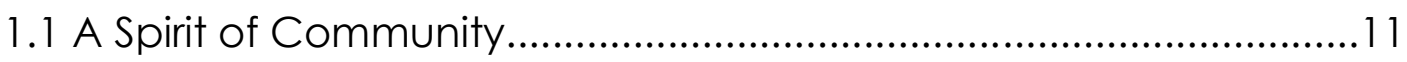

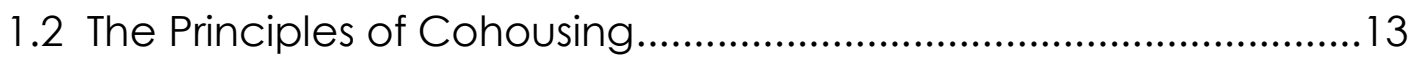

1.3 Convivium Cohousing for Seniors as Case Study...........................15

1.4 Senior Cohousing versus Intergenerational Cohousing...................17

1.5 'Community of Care' .........................................................................18

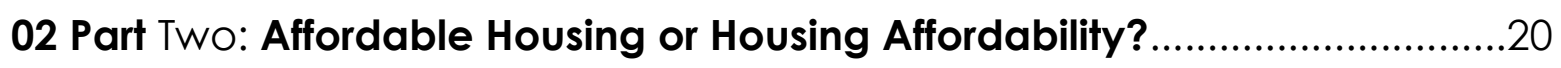

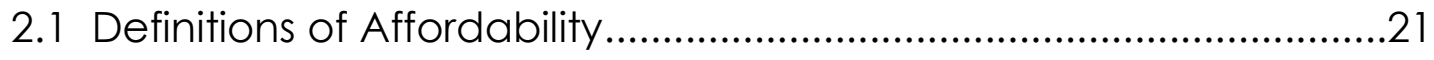

2.2 The 'Affordable Housing' Imperative in Housing Policy...................22

2.2.1 City of Ottawa Housing Policy ...........................................22

2.3 The New Housing Crisis: Housing Affordability..................................24 
2.4 Cohousing Benefits to Health and Health Budgets.

2.5 Financial Strategies for Creating More 'affordable'

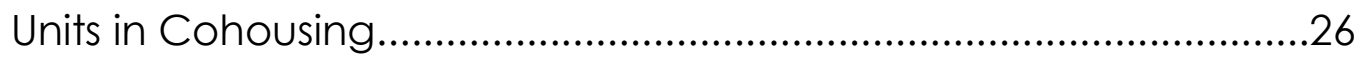

2.6 Case-Study: The Affordability Challenge within Convivium .............28

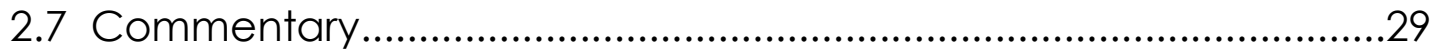

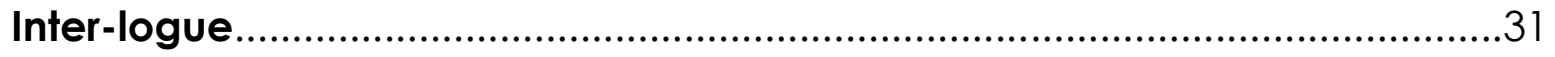

03 Part Three: The Complex Nature of the Development Process....................33

3.1 A Crucial Role: (Cohousing?) Development Consultant...................33

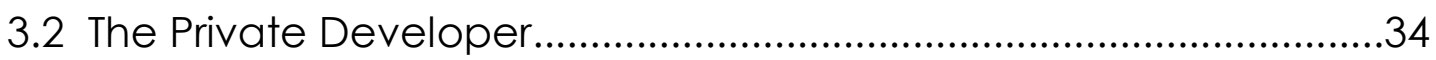

3.3 Roles of the Cohousing Development Consultant..............................34

3.4 Cohousing Development Consultant versus

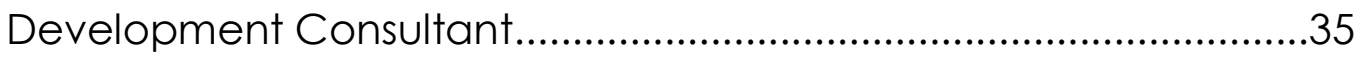

3.5 Limited Availability of Cohousing Consultants.....................................35

3.6 The Cohousing Development Process..............................................36

04 Part Four: Necessary Steps to Cohousing Success..............................38

4.1. Assessing the Feasibility of the Project (Land, Money \& Capacity)............38

4.2 Choosing a Legal Structure; Condo versus Co-op..............................39

4.3 Choosing a Project Delivery Approach; Alternative

Development Models..........................................................................41

4.4 Case-Study: Choosing a Development Model for Convivium ...........43

4.5 The Challenge of Finding and Securing a Site....................................46

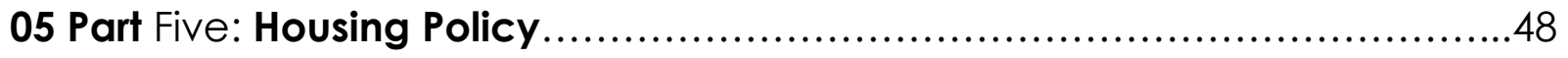

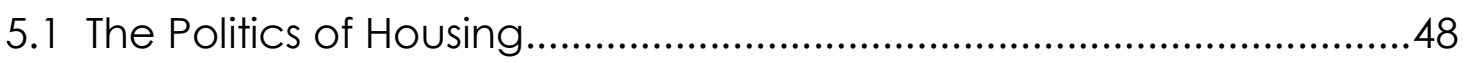

5.2 The Social Housing Priority..................................................................48

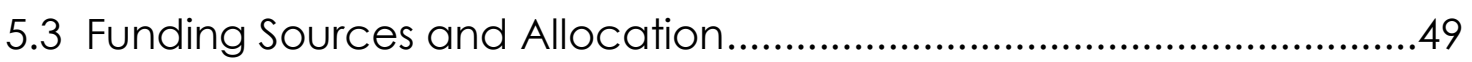

5.4. 'Aging in Place': A New Policy Direction..............................................51 
06 Part Six: Hurdles and Potential Development Opportunities (City of Ottawa)....53

6.1 Perceived Risks: A City of Ottawa Perspective .......................................53

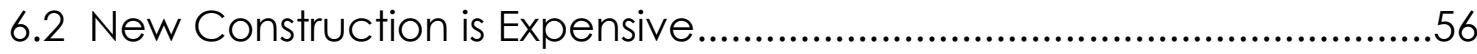

6.3 Creating Senior Cohousing: Potential Development Opportunities...56

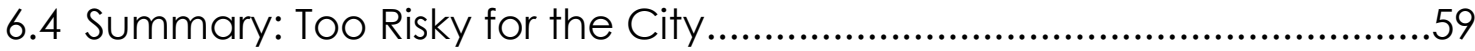

07 Part Seven: Conclusions: What Could the Future Look Like? ...........................60

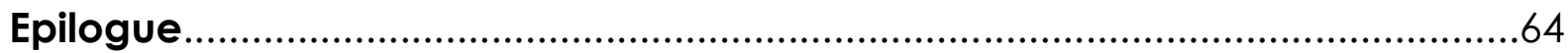

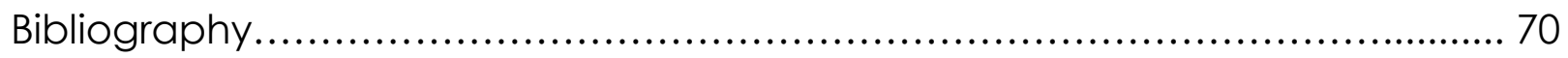

Appendices:

Appendix A: List of Sector Experts..............................82

Appendix B: List of Housing Organizations........................85

Appendix C: Strategies for Creating more Affordability.........86

Appendix D: Tool Kit of Interview Questions.......................91

Appendix E: Interview Transcripts..............................110

Graeme Hussey.....................................11 1

Jamey Burr..............................................133

Saide Sayah............................................155

Katie McCamant...................................179

Ronaye Matthew...................................195

David Kardish.........................................21 


\section{Prologue}

Arriving back to an ottawa winter is an unwelcome shock to my system; the warmth of the colorado sun and its deep blue skies are soon to be a thing of my past. I am returning to ottawa after 10 years of living in Boulder, colorado for what is to be an indefinite period of time. My life is about to take a very different turn. The relationship I had been in is over, I am turning 54 and am single for the first time in my life, and 1 am about to move in with my 86-year-old mother.

After a few months of readjusting to my new surroundings I began to contemplate a move, but 1 really didn't want to live alone. I was interested in living in community of some kind; one of my fondest memories of Boulder was the months I spent living in a Buddhist urban retreat centre where we each had a small private room but shared our meals and meditation sessions. I had heard about the only cohousing to be built in ottawa - Terra Firma cohousing in old ottawa East - and I wanted to know more. 1 decided to attend a few sunday common-house dinners to meet the residents and get a feel for the community. I was warmly welcomed and felt comfortable immediately, but unfortunately, there were no units available for rent or for sale. The founding residents had all lived there together for 15 years now, and all seemed content to continue to live together into their old age, having no plans to move out.

One day soon after my visit to Terra Firma, while I was driving home in traffic, 1 decided to turn the radio on to $C B C$. A documentary was playing on The Sunday Edition with Michael Euright about a group of older feminists in Paris who were about to move into their radical project called Babayaga House. A group of activist women, after many years of lobbying, had convinced the green party that was in power, to fund their women-only senior community living project. I was intrigued and captivated. What a great idea! A few months later I heard another CBC documentary2 about a woman from Montreal, janet Torge, who was starting her own housing initiative for older adults called Radical Resthomes. 1 decided to do a little research and stumbled on a blog section on the website for Radical Resthomes. Why not post my own comment and see what happens?

The comment board is full of notices from across canada: "am recently divorced and would like to share housing with others"; "I lost my wife a year ago and I am finding living alone, lonely. I would like to connect with others who would like to start a community"; "retired from my job 2 years ago and have been living alone and feeling isolated. Is there any shared housing in the Ottawa Region?" The stories went on and on - people in their 60's and 70's - mostly living alone - or couples whose children had moved far away. All were feeling alone and looking for the experience of connecting in community.

So, 1 decide to post a notice: "Woman living in ottawa looking for like-minded people to begin exploring how to create a cohousing community in the city centre." Within days there are some 15-16 responses. We begin to exchange emails and phone numbers. It becomes obvious that we need to meet if we are to take our interest any further. I arrange a meeting at my house; 16 people arrive, all bubbling with enthusiasm and motivation. All of us are women in our late 50's, early 60's and two in their

\footnotetext{
${ }^{1}$ The Sunday Edition with Michael Enright. Baba Yaga House: The Sequel. Documentary produced by David Gutnick, Aug. 11, 2013

${ }^{2}$ The Sunday Edition with Michael Enright. Living Arrangements Part 2: Radical Resthomes. Janet Torge speaks to a group in Ottawa, November 2, 2014.
} 
70's. We begin to plan our next moves and decide to call ourselves the silver wave. Soon we have one man join our merry band of women.

As part of our research, we decide to ask for a meeting with councillor David chernushenteo who has shown some interest in sustainability and housing issues. Five of us from silver wave meet at city Hall on January 6, 2015 with Mr. Chernushenko. He has invited Rebecca Aird along to the meeting. He senses there may be some shared interests and has decided to connect us. I recognize Rebecca from the sunday dinners that 1 attended at Terra Firma and am glad to see her again. She is a long-time Terra Firma resident.

Rebecca is also a colleague of Mr. Chernushenko; both have a shared interest in alternative housing. I hear from Rebecca that she is currently involved in a sub-committee of the ottawa East community Association called Sustainable Living ottawa East (SLOE). The group recently received a seed grant from a community foundation to further develop the idea of creating innovative housing for older adults in old Ottawa East. under the mandate of SLOE, Rebecca has approached the developers of Greystone village Development regarding incorporating some housing units for older adults within their development plan. She is also approaching sandy Hill community centre with an eye to a possible partnership that could provide community services including health care to village residents. Rebecca is also looking for innovative development approaches to house older adults with an eye to design, servicing, affordability and financial potential for developers. She is meeting with others interested in pursuing this goal on january 27 and extends an invitation for us to join her.

1 can't believe it, there is already a group of older adults trying to create a cohousing community in ottawa! Those of us in silver wave recognize that there is not much point in trying to begin a new initiative when there is already one under way; most of us decide to join the group that Rebecca has been guiding. This group is known as $1 H O A$, the innovative Housing for Older Adults in Old Ottawa East. SLOE had been deeply involved in the planning for Greystone village and was involved in the city approval process of the master plan for the oblate Lands.

over the next year a committee works hard to position themselves to negotiate with The Regional Group (the developers of Greystone). A Design Workshop is organized and takes place in june 2015. Fifty people attend the design workshop and enthusiastically put forward ideas to present to Regional. Discussions with Regional have been ongoing and a number of possibilities are under discussion. We prepare for a meeting with Regional to be held on october 6, 2015. A Finance and ownership committee has been established and in November 2015 a workshop on the topic takes place.

We enter the meeting with expectations; soon we realize we have been too hasty in our assumptions. It seems that the development of Greystone has many more players than we first realized. Regional is now in discussions with ccoc regarding the redevelopment of the Deschatelets building, as well as a possible affordable-housing project. It is also in negotiations with a private developer to buy a piece of property on which to build a senior Residence.

Around this time, more people begin to attend the 10 HA Steering committee meetings. Many of these new attendees are on the organizing committee for the Finance and ownership workshop that had taken place in November. This group begins to coalesce into a "potential resident group" under the leadership of Lynne Markell - the Chair of the Finance and Ownership committee. By January 2016 there is talk of forming a new organization (Convivium). Rebecca and the rest of the IHOA Steering 
committee agree to this proposal. convivium cohousing for seniors is incorporated into a new nonprofit organization soon after. Rebecca Aird, who never intended to become a resident of the new community, takes an advisory role and helps broker a meeting with Regional in summer of 2016 on a potential site in Greystone.

Some of those who first showed an interest in $11+0$ A have moved on - either feeling they did not have enough money to afford a unit in the project, or because it just seems too hard and too much effort to overcome all the obstacles. It seems to me that convivium is now (May 2018) a group made up mostly of members who did not initially begin the journey together as part of IHOA. After three years some of us are getting very tired. Why is this so difficult?

It is now winter 2018 and my mother will turn 96 this May. She would be in an old-age residence now, if I didn't still live here; she could not live alone anymore. I have watched all of her sisters lose their husbands over the last 10 years, each of them living alone afterward - not wanting to move into the alternative, an old-age home. Two of her sisters have now passed away, and most of her friends have as well.

Most of my friends never had children and will not have a daughter or other family member to support them in their old age. What will we do? What will I do? I want to make sure that there are better alternatives for aging in community than are currently available. Surely there must be better ways to grow old. 


\section{Questioning the SENIOR COHOUSING CHALLENGE: \\ A Cross-Sector Analysis of Interviews with Leading Experts}

\section{Introduction}

\subsection{What is the purpose of this research?}

The overwhelming majority (up to $90 \%$ ) of self-organized groups trying to create a cohousing project in Canada and the USA never realize a built project. ${ }^{3}$ This is a staggering statistic. To understand what underlies this failure, it is necessary to ask a number of pertinent questions. Why do so few cohousing projects succeed in realizing a built project? What factors contribute to the difficulties faced by cohousing groups in their project development?

Creating a senior cohousing project can be conceived as taking place in two important areas: the community-building process and the development of the built project. For the purposes of this thesis we will focus on the sectors necessary to manifest the community vision into a built project. The thesis will analyze the perspectives of professionals representing the following organizations and structures: the real-estate development sector (private and non-profit); the financial sector; government departments responsible for establishing and implementing housing policy and cohousing development consultancies. By interviewing the diverse stakeholders involved in the development of a cohousing project we hope to come to a better understanding of the challenges and opportunities of this venture. It is hoped that this process will point to innovative solutions and approaches that might support a group of older adults to increase their odds of realizing a cohousing project. This research will focus on the process of creating such project in the Ottawa area, but it is expected that lessons learned will be transferable to other parts of Canada.

\footnotetext{
${ }^{3}$ Christian. Creating a Life Together. 2003 Pg. xv; M. Critchlow Workshop; S. Raymond, Solterra. http://solterraco-housing.com (with the availability of cohousing development consultants in $\mathrm{BC}$ the, figures for projects succeeding in $\mathrm{BC}$ may need revision)
} 


\subsection{Why is this important to Canadian seniors and our society as a whole?}

The demographics of most Western populations are changing rapidly. In Canada alone, for the first time in our history, the number of people over the age of 65 now outnumber those under the age of $14 .{ }^{4}$ It is predicted that by the year 2030, those over the age of 65 will make up close to $25 \%$ of our population. ${ }^{5}$ This 'grey tsunami' will cause major disruptions to our socio-political fabric, as well as to modes of financing government pensions and programs.

Many of the 'baby-boomers', who will make up the majority of the new seniors by 2030, have lived educated and politically engaged lives; they will not accept 'living-out' their old age in institutional settings where their choices are managed, and their personal resources are underutilized. Current models are certainly unsatisfactory regardless of the generation of residents or the personality of a generation.

Cohousing may be one of the most viable alternatives in looking for innovative ways for seniors to 'age in place'. ${ }^{6}$ Creating a 'community of care' in the cohousing environment means that seniors can 'age in place' and importantly 'age in community' in ways that are more connected than aging alone in a single-family home. In this way, cohousing can also help to address the upcoming demands on the health care system. Research has shown that delayed entry into retirement homes, or long-term care facilities, saves the Canadian taxpayer $\$ 45,000$ per person, per year! ${ }^{7}$ In addition, senior cohousing addresses the need for supportive housing that is economically, socially and environmentally sustainable.

The number of older adults suffering from isolation is staggering, and this trend is only set to worsen. The UK has recently acknowledged the seriousness of this social condition by labelling

\footnotetext{
${ }^{4}$ Statistics Canada (2016 Population Census).

${ }^{5}$ Ibid.

6 'Aging in place' means having the health and social supports and services you need to live safely and independently in your home or your community for as long as you wish and are able. https://www.canada.ca/en/employment-socialdevelopment/corporate/seniors/forum/aging.html ; 'Aging in place' is the ability to live in one's own home and community safely, independently, and comfortably, regardless of age, income, or ability level. U.S. Centers for Disease Control and Prevention. https://www.cdc.gov/

${ }^{7}$ Raymond, Shelley, Solterra Project http://solterraco-housing.com
} 
it an "epidemic of loneliness" and appointing a Minister of Loneliness. ${ }^{8}$ The majority of "the lonely' are seniors, both men and women, but the number of senior women living alone easily surpasses the number of senior men living alone. By the age of 75 , nearly $40 \%$ of women are living alone in comparison to $15 \%$ of senior men. ${ }^{9}$ Within institutional settings (retirement homes and long-term care facilities) the number of older women also outnumbers those of older men ( 7 in 10 are women) ${ }^{10}$. This gender imbalance in the senior population is notable.

The demographic of an aging population and the erosion of the social structure of the 'nuclear family' demand that alternative solutions be found for housing older adults and caring for seniors. When the time for change in the living situation of a senior comes, the choice of options is limited, and most often relates to one's financial capacity. The wealthy senior can choose to continue to live in their home and arrange for a caregiver; the less fortunate may utilize inadequate in-home support services funded by the government. Those with the financial means may choose to enter the privately-run (for profit) senior residence sector; those with below-median income must turn to subsidized 'affordable housing' and supportive housing alternatives.

These restricted options are not adequate in addressing the human need for community and the desire to age with dignity and self-determination. The cohousing model offers the potential of an innovative housing approach. It has, however, so far met with near insurmountable obstacles. By analyzing the challenges communities are facing as they try to create an innovative housing model of a self-organized, co-caring, 'community of care, ${ }^{11}$ it is hoped that new strategies and policies may be adopted to support and facilitate innovation in caring for and housing seniors, in a way that maximizes choice and the seniors' own preferences and initiatives.

\footnotetext{
${ }^{8}$ Yeginsu, Ceylan. "UK Appoints a Minister for Loneliness". The New York Times. Jan 17, 2018.

https://www.nytimes.com/2018/01/17/world/europe/uk-britain-loneliness.html

${ }^{9}$ Statistics Canada (2016 Population Census); Infographic on seniors living alone.

${ }^{10}$ Statistics Canada (2016 Population Census); 7 in 10 seniors living in collective dwellings are women

${ }^{11}$ NHS Alliance (England) http://www.nhsalliance.org/wp-content/uploads/2014/10/THINK-BIGACT-NOW-FINAL-1.pdf
} 


\subsection{What are the questions?}

In an ageing society, cohousing for older adults, offers one way of addressing the existing and forthcoming challenges of housing and sustaining the health of elders. This research is interested in finding ways to facilitate the development of elder cohousing by identifying the full spectrum of challenges faced by self-organized groups of adults looking to create a cohousing project, as well as looking at possible solutions. What are the challenges that make it difficult to create a senior cohousing project? Perspectives offered by experts across the spectrum of stakeholders will be analyzed with an eye to identifying innovative solutions. We will look at current government policies and ask what impact they may have on the potential to support the building of a cohousing project? Do organizational structures that operate within the market-driven housing economy (with its 'for-profit' bias) resist any movement toward a community oriented, shared economy of resources? What innovative partnerships might support the creation of the sustainable cohousing community?

\subsection{What methods are used for this research?}

This thesis adopts a mixed-methods approach.

Written work on the challenges of creating cohousing have largely focused on the views of founding members (and the general membership) of cohousing communities that have failed to realize a cohousing project. These studies have articulated the obstacles from a single point of view - most often that of the member participant. In the case of McCamant and Durrett, their

widely referenced handbooks on cohousing represent a broader perspective that reflects the depth and breadth of their experience as architects and developers. They are not, however, the compilation of the many voices that would need to be invested in the success of such a project. I was not able to locate any research that attempted a cross-sector analysis from the perspective of the many different stakeholders themselves.

In the absence of primary-source data representing these perspectives, I decided to approach the key players directly. New data has been collected through a series of key informant interviews representing stakeholders involved in the process of creating a senior cohousing project. These interviews constitute the primary-source data for this research thesis. The 
emphasis on the diversity of viewpoints is intended to draw out the complexity of issues, as well as to identify differing perspectives on the challenges and opportunities of creating a senior cohousing community.

The inclusion criterion for the key informant interviews was expertise in a sector related to the development of the Convivium Cohousing for Seniors (Convivium) project here in Ottawa, or other cohousing communities in North America. Nine experts were identified as research participants, all of whom are professionals, publicly known in their fields; leaders representing government departments dealing with housing policy, community non-profit housing corporations, and real-estate developers, as well as, project managers, cohousing consultants, architects, and founding members of several cohousing projects.

The interviews were conducted using a semi-structured approach. A list of general questions related to the topic were formulated and then a second list of questions was developed for each individual participant. The interviews lasted from one to two hours. After the interviews were recorded, they were transcribed for analysis and edited for inclusion in the submission of this thesis document. Relevant themes were identified and coded in each interview, analysed and later embedded in the research text.

The development process of Convivium Cohousing for Seniors has been used as a case study. The methods employed include auto-ethnography, and participant-observation techniques. I have been personally involved as a participating member of Convivium for the last 2 years and have served as a Board Member for the last year and a half. This has afforded me the opportunity to observe, first-hand, the struggles and rewards of trying to create a cohousing community. Using Convivium as a case-study serves to outline areas of decision-making, the difficulties encountered in the process, and the best practices that may support future communities wanting to realize a similar project. Both the current board members and general members have expressed enthusiasm about the possibility of an analysis of the process of 
establishing a cohousing project for seniors. All insights will be shared with Convivium as well as with other cohousing projects showing an interest.

My personal attendance at conferences on aging, housing finance, and cohousing over the last 3 years has contributed to my knowledge of the topic and offered valuable insights. ${ }^{12}$ In addition, the information gained through attendance at several presentations and workshops offered by current leaders in the cohousing movement has added to the knowledge represented in this research text.

A document analysis of materials written about other cohousing communities in formation, in development, and in construction - as well as those completed - was also incorporated into this research as a point of comparison. Analysis of radio and television documentaries ${ }^{13}$ related to the subject have also contributed to the discussion.

A crucial first step in laying the groundwork for the future viability of cohousing as an alternative for older adult living, is asking the questions and seeking the answers to the many complex challenges of creating a project. The multi-view perspective of this thesis research also speaks to new approaches being brought forward by leaders in the building industry that include the possibility for innovative partnerships between developers, non-profit organizations and governments. ${ }^{14}$

\subsection{A Note on the contemporary nature of this thesis:}

The lens of this thesis focuses squarely in the present. With this in mind, it seeks to address the current realities of an aging population and a disintegrating social structure. It does not try to substantiate the role that cohousing can play in creating a healthier and happier senior population; rather it concerns itself with how to move forward the project of creating a building typology that offers an alternative lifestyle for older adults in a time of societal challenges.

\footnotetext{
${ }^{12}$ Refer to the Bibliography for a list of conferences attended

${ }^{13}$ Refer to Bibliography for names of documentaries.

${ }^{14}$ Henriquez... et al, Citizen City. 2016.
} 


\subsection{Process as Product}

The backbone of the process for the identification and analysis of the challenges of creating a senior cohousing project in the Ottawa context was a series of unanswered questions related to the topic. In one sense this process is also one of the products of this research. The set of questions that guided the research are also offered as a tool-kit for the inexperienced cohousing group to reference for their own group process. The questions asked of interview participants are questions that would be relevant to any group in the formative and development stages of a cohousing project. The answers offered by different sector experts that any group approaches, can serve as sign-posts for the journey through the complexity of the development process.

Solutions to some of the challenges identified in this research are still being sought by even the most experienced of cohousing development consultants. ${ }^{15}$ This thesis offers recommendations and directions to explore, rather than definitive solutions, to some of the most pressing difficulties in creating a cohousing project. It hopes to make the process easier for the many people who have the aspiration to live in a cohousing community by identifying the road-blocks in the map of their dreams. ${ }^{16}$

\footnotetext{
${ }^{15}$ Interview with Katie McCamant. Pg. 193.

e.g. "I think the big issue in the U.S. housing market right now is that new housing is out of reach for a huge portion of middle and moderate-income families, and I don't have a solution for that. ... know these budgets better than anyone, and I can't figure out how to make it cheaper - without subsidies."

${ }^{16}$ Interview with Ronaye Matthew. Pg. 209.

"If there was someone who knew more about (developing cohousing) than me, then that would be my question: how do we make this easier? It's always how to make this easier, and I don't know if there's a way."
} 
Part One

\section{What is Cohousing?}

\subsection{A Spirit of Community}

What is Cohousing? The meaning of the term cohousing can be confusing. This is partially due to the association the word raises for many who grew up in the 1960's and 1970's. Communal living in which students shared a large house (communes), or the off-the grid sustainable farm communities (that 'hippies' lived on), are some of the first images that come to mind. The associations to these early forms of co-living are misleading.

Cohousing is also, not, a term for a legal ownership structure. Ownership structures are mandated and regulated under legislation. Condominiums and cooperatives (housing co-op) are both legal structures. A cohousing project does need to choose a legal structure during its development, but the word cohousing itself is not a legal structure. Most cohousing to date have chosen to work with the condo, or strata title as it is easier to finance, but some groups chose to work with the cooperative model.

These are some of the things cohousing is not, but what is it? Most definitions of cohousing agree as to the basic principles and nature of a cohousing project. However, some recent alternative housing approaches have co-opted the terminology 'cohousing', but are more accurately 'shared houses', often owned by one person, and less often by a small group. Montreal's Janet Torge's, Radical Resthomes and Beverley House in Toronto, as well as the newly formed Wine on the Porch in Toronto, are such projects proposing a single-family home for shared living. ${ }^{17} \mathrm{~A}$ traditional cohousing community shares common space and amenities (as do these shared houses), but also provides privacy in separate living spaces - either detached

\footnotetext{
${ }^{17}$ Doug Tindal, "Toronto Cohousing Communities". Wine on the Porch Website. April 25, 2016.

https://wineontheporch.wordpress.com/2016/04/25/toronto-co-housing-communities/ (accessed Feb. 25, 2018)
} 
houses, or apartment units. In addition, the importance of an equality of structure within a group is a value that is more difficult to achieve if one person is the sole owner of the house.

The Cohousing Association of the United States (Coho-US) defines cohousing in the following way:

"Cohousing is an intentional community of private homes (or units) ${ }^{18}$ clustered around shared space. Each attached or single-family home (or unit) has traditional amenities, including a private kitchen. Shared spaces typically feature a common house (or common room), which may include a large kitchen and dining area, laundry, and recreational spaces. Shared outdoor space may include parking, walkways, open space, and gardens. Households have independent incomes and private lives, but neighbors collaboratively plan and manage community activities and shared spaces." ${ }^{19}$

Cohousing is first and foremost a word to describe a lifestyle choice; a choice which indicates that a person chooses to live in an environment that fosters community and collaboration; the choice to live in cohousing acknowledges the loss of social connectedness in our contemporary society. The old 'small-town' community feel and the traditional connectedness of village life, have given way to isolation in rows of single-family developer housing, or condo living.

What we have lost is difficult to express in words, but we can all relate to times of social isolation that can create loneliness and personal suffering. Kathryn McCamant, architect, celebrated author, and advocate for cohousing described what she feels we have lost in this way:

"Most of my neighbours are not my best friends, and they're not family, but the level of trust and my gut feeling that they've 'got my back' is an amazing thing. I think most people don't have that.... The depth of that relationship is pretty interesting and amazing... it brings in to your life this thing that I think we've really lost. I think it was natural in human habitation, in the village, in

\footnotetext{
${ }^{18}$ my parentheses

19 "What is Cohousing?", The Cohousing Association of the United States (CoHo). http://www.cohousing.org/ (accessed Sept.
} 2017) 
the church, in the neighbourhood. You didn't have to like Mrs. Smith to show up with chicken soup when she was sick, right."20

The definitions offered above only scratch the surface of the cohousing experiment. To further understand the underpinnings of the endeavour we need to look at the founding principles of cohousing.

\subsection{The Principles of Cohousing}

Most advocates of cohousing agree that the foundation of a cohousing community rests on a number of principles, and that without these principles, the community is not truly a 'cohousing' project. These features are outlined in the vision statement of the community and usually include the following: ${ }^{21}$

Designing for Community: The physical design of the project will encourage social interaction amongst the residents as well as providing for personal privacy. In rural settings, communities tend to take the form of cottage like homes with a central common-house and community green space. In metropolitan areas the arrangement of space may take place in an apartment-style building in which each household has an apartment of their own with shared communal areas for social interaction. The size of the community should be limited to 20-35 units in order to maintain a sense of connection amongst residents. Designing for a strong 'sense of community' is a key component. $^{22}$

Healthy Relationships that Balance Privacy and Connection: Cohousing respects an individual's need for privacy as well as community. Each home/apartment is selfsufficient with its own kitchen facilities, but residents will have the opportunity of sharing space and activities. The shared spaces may include a dining room and kitchen, a living room, library, guest rooms, laundry rooms, workshops and others. Residents choose their level of engagement, but simultaneously commit to be a part of community living.

Participatory Planning: All future residents will participate in the process of organizing and developing the project; resident involvement in the designing and planning of the

\footnotetext{
${ }^{20}$ Kathryn McCamant (Architect; Principal of Cohousing Solutions; Author of Creating Cohousing), personal interview with the author, Nov. 6, 2017. Pg. 192.

${ }^{21}$ Canadian Cohousing Network, http://www.cohousing.ca/ (accessed Sept. 2017) and The Cohousing Association of the United States. http://www.cohousing.org/ (accessed Sept. 2017)

${ }^{22}$ Looking at Design for 'sense of community' is outside the focus of this thesis
} 
community is a key component of cohousing. The self-initiated and self-organized quality of cohousing is central to the idea of the participants determining and controlling their own environment and lives - living independently and interdependently.

Non-hierarchical decision-making process: The decision-making process will be inclusive and transparent. All households and resident's voices need to be heard and considered, and decisions need to be reached in a respectful manner. Many, but not all, cohousing communities have adopted a consensus-based model of decision making for their internal organization. If the community is led by a director who establishes policies unilaterally (in the hierarchical sense) it is not considered cohousing (more will be said on this later). The following statement made by K. McCamant at the $3^{\text {rd }}$ North American Cohousing Conference in Seattle (1997) speaks to the spirit of this principle of cohousing: "There are leadership roles, but not leaders. Even though there is often a "burning soul" that gets the community off the ground, and another that pulls together the financing, and another that makes sure you... and the group has babysitters for meetings, the community is not dependent on any one person." ${ }^{23}$

Self-management after move-in: After construction is completed, the residents of a cohousing community will self-manage the building and environment themselves, as well as administer the day to day operation of the community. This approach depends on the sharing of financial and operational management. All residents will contribute their time and energy in a collaborative way to care for the building and its inhabitants. The residents are each responsible for their own finances; there is no shared communal economy. The community is not to become a primary source of income for the residents.

Commitment to Environmental Sustainability: Cohousing projects tend to be environmentally conscious communities with a commitment to recycling, using alternative energy sources to save on energy costs, and designing with an eye to energy efficiency, and using green space for gardening and recreational areas. They also tend to encourage pedestrian accessibility and aim to minimize automobile use and its resulting carbon footprint. Many will use a car-sharing strategy to minimize car ownership and parking spaces.

${ }^{23}$ Kathryn McCamant, 3rd North American Cohousing Conference Seattle, Sept. 1997. 


\subsection{Convivium Cohousing for Seniors (Convivium) as a Cohousing Case-Study}

The personal involvement of the author of this thesis in the senior cohousing project, Convivium, played a significant role in the motivation for this research. The frustrations, challenges, rewards and enjoyment of working with others toward this cohousing project for older adults has fueled this work. As the author, I have sought answers to many of the outstanding questions regarding how to achieve the creation of a successful cohousing project. I have turned for guidance to the expertise of leaders in all the sectors related to the development of a cohousing project in the Ottawa area, and most specifically to the development of the Convivium Cohousing project.

Convivium Cohousing for Seniors requires some introduction and explanation. In April 2016, 'Convivium' was incorporated as a non-profit organization to establish a seniors cohousing development in the core of Ottawa. Creating this formal structure also supported the submission of proposals and the application for funding and grants.

The roots of Convivium lie within a group of Old Ottawa East organizations and seniors who banded together under the name Innovative Housing for Older Adults in Old Ottawa East (IHOA), under the leadership of Rebecca Aird. Rebecca was a long-time community advocate, and the Chair of Sustainable Living Ottawa East (SLOE) at the time. After a number of workshops held by IHOA in the spring and fall of 2015 - to engage interested members in the process of defining financing options, design guidelines and organizational structure - the group took a somewhat different turn. The original aim of IHOA had been to create seniors' housing on the Greystone Development site in collaboration with the project developer The Regional Group (Regional). When Regional's interests took a different turn toward the redevelopment of the Deschatelets building (Oblate Fathers' Residence) into a Community Hub, incorporating affordable housing built by CCOC into the project, the developer's interest in IHOA's initiative began to wane. It was around this time that the potential residents of the group were re-forming under the Convivium banner. 
After several attempts to collaborate with Regional - around a pre-designed building - did not produce a viable option for a senior cohousing building, Convivium began to cast a wider net. It has to date explored the possibility of hiring a design/build team of developer and designer; a team of Architect and builder; of buying land outright and operating as its own developer; of engaging a developer who already has land to build a turnkey project. The complexity of the development process has meant that Convivium, although it has contracted with Cahdco for specific tasks, continues to look for a development consultant who can assist in the overall development process. Unfortunately, to date, there are no cohousing development consultants working out of Eastern Canada. At the time of this writing, Convivium was considering hiring Cahdco (the development arm of $\mathrm{CCOC}$ ) to take up the role of development consultant. More will be said about the role of development consultant later in this thesis.

By this time, Convivium had upward of 40 members (it now has 64) with almost 40 more people on a waitlist. All members are over the age of 55, with women representing two-thirds of the membership. There are a number of married couples in the group at present, but the vast majority are single older adults. In late 2017, a new class of membership was introduced as a way of determining which members were serious in their commitment to the project. The funds raised for this 'equity' member status, were sorely needed as a way to pay for rising development costs: lawyer's fees, co-operative incorporation costs, and consultancy fees. The new request for a substantial monetary investment proved to be a watershed moment for the group, testing members on their commitment. Fourteen households decided to make the investment to become 'equity' members; the rest have remained general Convivium members.

Convivium initially organized around a board of directors and a number of committees tasked with goals. Committees were established to deal with the areas of finance and ownership, land acquisition, design guidelines, supportive services, and membership and communications. The group held regular board and general membership meetings, as well as communal dinners. After some members began to express the desire for a more consensus-based process, the group decided to hire a facilitation consultant to educate and guide the group in the facilitation 
and consensus decision-making processes. ${ }^{24}$ Thereafter, Convivium made the effort to adopt new language around its decision-making processes, renaming the Board, the Coordinating Committee and the Committees, Working Groups. Facilitation has been shared around the 'equity' members with some success, but moving the group toward a truly inclusive consensus model has been a slow process.

Two years since the formal establishment of Convivium, and more than three years since IHOA began its exploration into the creation of a cohousing project for older adults, the membership has reconfigured into a group unrecognizable from the original participants of IHOA. The commitment, time and effort required by volunteers is daunting, and many were unprepared for the long haul; it would seem that most people prefer to buy into a project once it has been completed, and when the development risks are behind. Many of those currently forging ahead are 'war-weary', but willing to continue to commit their time and energy to the cohousing project.

Throughout this thesis, I will continue to refer back to my personal experience (participant observation) in the journey with IHOA and Convivium, as a way to ground the discussion and analysis in a lived experience. Using Convivium as an auto-ethnographic case-study can help to validate, or throw into question, some of the reflections offered in the nine interviews conducted with development experts.

\subsection{Senior Cohousing versus Intergenerational Cohousing}

A last note on the distinction between 'senior' cohousing and 'intergenerational' cohousing. There is lively and ongoing debate about the advantages and disadvantages of both approaches, and in some unusual cases, intergenerational cohousing has been placed side-byside with senior cohousing. ${ }^{25}$ Other terminology is sometimes used, such as 'senior-focused,' or cohousing for 'older-adults', or 'elder' housing, but the essential point here is the difference

\footnotetext{
${ }^{24}$ Margaret Critchlow (Cohousing Development Consulting - CDC, associate). Nov. 2017.

${ }^{25}$ Sage Cohousing (intergenerational) and Silver Sage (senior cohousing) in Boulder, Colorado.
} 
between the diversity of the intergenerational model, or the predominance of one generation seniors - in the community.

One of the arguments for the diverse generations model is, that as seniors in cohousing age together, the issue of care becomes greater; there are less able-bodied adults to help others out. If some residents are from younger generations (some senior cohousing in Denmark has incorporated student rentals) those people can support the seniors as part of their rental agreements. ${ }^{26}$ One argument given for the senior-focused community is that the concerns of the older population are not shared by those of younger generations, and therefore are not priorities in decision-making times. In addition, several of the development consultants interviewed pointed to the fact that most seniors are retired and have more time and desire for community interaction than families whose adults are busy working and have family responsibilities.

\section{5 'Community of Care'}

A central theme of senior-focused cohousing is the question of how much help and support a resident can expect from other residents. Creating a 'community of care' is one of the defining characteristics of a senior cohousing project. In most cases, the consensus is that residents should expect to help each other in practical matters like buying groceries, or cooking dinner for a sick member, but not have the responsibility for providing personal care, such as giving a member a bath, or shower. ${ }^{27}$

A comprehensive history of senior-cohousing, or cohousing in general, is outside the scope of this thesis, but it is of interest that both originated in Denmark in the 1980's. The first seniorcohousing - Midgaarden in Copenhagen - was established in 1987 by a group of nine single

\footnotetext{
26 'Intergenerational' retirement home sees students live alongside the elderly" (Humanitas retirement home in Deventer, Netherlands). Dec. 7, 2014 https://www.ctvnews.ca/health/intergenerational-retirement-home-sees-students-live-alongsidethe-elderly-1.2136659

${ }^{27}$ Max Pedersen, "Senior Co-Housing Communities in Denmark", Journal of Housing for the Elderly, 2015. 29:1-2, Pg. 126-145, https://doi.org/10.1080/02763893.2015.989770
} 
elderly women. ${ }^{28}$ The project received publicity and other groups aspired to create similar projects. Many never succeeded, but by the mid-1990s, around 30 senior cohousing projects had been built. ${ }^{29}$ What is of interest here, is that even in our current environment in North America, the leaders, or "burning souls', of senior cohousing initiatives have been women.

${ }^{28}$ Pedersen, 2015.

${ }^{29}$ Pedersen, 2015. 


\section{'Affordable Housing' or Housing Affordability? A Pertinent Question for Cohousing Projects}

One of the defining characteristics of most senior cohousing projects in North America is the desire to create housing for older adults that is affordable. Cohousing groups usually begin with the intention of accommodating households of different incomes (including low to moderate income residents) so as to meet the affordability requirements of its members; this has proven to be a difficult goal to achieve. A 2010 review by the Cohousing Association of the United States (CohouS) $)^{30}$ of the number of affordable housing units that were realized within cohousing projects in the USA, ${ }^{31}$ stated the following:

“...a substantial minority of communities have successfully sought varied and innovative ways to assist more moderate-income households to be part of their communities. A number of communities have even used their own money, i.e., a form of re-distributive economy. It is interesting that private means are more common than public resources. This points to the need for more public programs to assist low to moderate-income households who want to be part of cohousing communities."${ }^{32}$

The difficulty in incorporating low to 'moderate-income' ${ }^{33}$ seniors in a cohousing project has many roots. One important reason is that the senior cohousing project, as it is currently configured, exists primarily as an ownership structure. Some cohousing communities have found ways to incorporate a few rental units (mostly at market rate), ${ }^{34}$ but unit rentals are the exception to the rule. The current reality of the ownership structure for a cohousing project tends to exclude those of lower income. The understanding of this situation does not only lie

\footnotetext{
${ }^{30}$ CohoUS is the website in the US for the topic of cohousing. It is the largest online resource with directories of cohousing projects and cohousing professionals

31 "Affordable Cohousing Toolkit: A Summary of Public and Private Affordable Housing Programs" by Affordable Cohousing Task Group. The Cohousing Association of the U.S., June 2010.

32 Ibid.

${ }^{33}$ Low to moderate income can be understood as not exceeding $120 \%$ of the median household income for a specific area (for 2015 in Canada that median was $\$ 70,000$ per household (this figure includes single to family households combined) For a single man it was $\$ 48,000$ and for a single woman, $\$ 32,000$ in 2011. http://www.statcan.gc.ca/tables-tableaux/sumsom/l01/cst01/famil21a-eng.htm \& http://www.statcan.gc.ca/tables-tableaux/sum-som/l01/cst01/famil107a-eng.htm

${ }^{34}$ Habourside Cohousing, Sooke, BC.
} 
with the preferred ownership structure of most cohousing projects, but also with current government policies on 'affordable housing'.

\subsection{Definitions of Affordability}

Any discussion regarding the desire to include units that can be considered affordable, to low and moderate-income residents in a senior cohousing project, must begin with an understanding of the formal (federally recognized) and the informal understanding of the terminology of "affordable housing". The Central Mortgage and Housing Company (CMHC) on behalf of the Federal Government of Canada, provides the commonly used definition for 'affordable housing'; "to be affordable, a household should not spend more than 30 percent of their gross income on shelter costs". The definition in the Provincial Policy Statement (PPS) issued under section 3 of the Planning Act is based on this commonly used definition. Municipalities (including the City of Ottawa) must be consistent with the PPS in their land-use planning and development decisions.

Under this definition, "affordable housing" is directed to those most in need. Affordable housing that meets this definition is most often referred to as "social housing", or housing that is subsidized by the federal and provincial governments. Therefore, the widely accepted understanding of the term "affordable housing" has come to represent social housing that is subsidized by government funds.

On the other side of this conversation, is the genuine meaning of "affordable housing" that points to "housing that is affordable". Housing that is available at affordable cost to the average Canadian is another story entirely. Affordability must not only be thought of in terms of the lowest income earners with large families who are struggling to make ends meet; there are many Canadians who do not qualify for assisted housing, but whose need is palpable. ${ }^{35}$

Of 10,000 names on the waiting list for subsidized housing in Ottawa, only 2000 are seniors. This may lead one to assume that seniors are not in need of housing that is affordable; but this would be a misconception. Many seniors, especially single women are on fixed incomes that fall

\footnotetext{
35 Jacqueline Hansen · CBC Business News · Posted: November 29th 2017, 1:17:19 PM: Ultra-low rental vacancy rates highlight 'desperate' struggle to find affordable housing. Jennifer Keesmaat quote
} 
well below the average Canadian income, ${ }^{36}$ but not low enough to qualify for 'affordable housing'. It is true that they may not be the demographic most in 'need', but certainly their need for housing that is affordable, is real.

\subsection{The 'Affordable Housing' Imperative in Housing Policy}

The Government of Canada has long had an affordable housing strategy and the current Provincial and Municipal governments have taken their cue from these policies and funding allocations. The history of affordable housing programs and the financial support to operate them, is far too broad a topic to cover in this thesis. For the purposes of this discussion, a short summary of the history of housing policy in Ontario is offered in the footnotes; it is hoped that it may help to indicate the long tradition of support for 'affordable housing' in Ontario and Canada. ${ }^{37}$

\subsubsection{City of Ottawa Housing Policy}

The City of Ottawa positions it's housing program within the Community and Social Services department; this in itself reveals the dominant view of housing as a social-housing issue. The City of Ottawa's latest housing programs show a repeated emphasis on the same demographics that have become the traditional areas of focus: homelessness, support housing for mentally and physically challenged individuals, and social housing for those most in need. The needs of low to moderate income seniors are shown peripheral concern. The City's objectives are set out in the 10 Year Housing and Homelessness Plan. ${ }^{38}$ Within this overarching 'plan', Action Ottawa

\footnotetext{
${ }^{36}$ Rea W, Yuen J, Engeland J, Figueroa R. The dynamics of housing affordability. Perspectives on Labour and Income (Statistics Canada, Catalogue 75-001) January, 2008; 9(1):15-26. "Those living alone, and female lone parent families are the most likely to spend above the benchmark: $42 \%$ and $44 \%$ respectively in 2004 , more than double the proportion in the population as a whole (20\%)."

37 Burr, Jamie. History of Affordable Housing in Ontario. Unpublished material shared with the author of this thesis. Government support for "affordable housing" at a federal and provincial level has been an uneven road. For our purposes the important milestones were as follow: In the 1980's mandatory cost-sharing between the federal and provincial governments was introduced with the proviso that the provinces would now manage the housing programs and decide which groups would get money. In 1992 The Government of Canada cancelled all new funding due to the pressure of an economy in recession and deficit spending. Bob Rae, premier of Ontario between 1990 and 1995 pledged to continue to fund affordable housing and increase spending to cover the federal shortfall. In 1995 the conservative Michael Harris was elected premier on the platform of eliminating wasteful spending; the cancellation of affordable housing programs was one of its first actions. The new provincial government then transferred responsibility for subsidizing and managing social housing to municipalities, but without adequate funding. A compromise is reached in which the Government of Canada agrees to provide short-term capital grants to create new affordable housing, but provincial governments will design the programs and determine which sectors will receive the money. This system continues to this day.

${ }^{38}$ City of Ottawa. 10 Year Housing and Homelessness Plan. Sept. 25, 2013 https://ottawa.ca/en/residents/socialservices/housing\#our-10-year-housing-homelessness-plan
} 
(first established in 2002) (s) $^{39}$ is the primary program for increasing the supply of low-income affordable housing in Ottawa. Its emphasis is on building new affordable rental housing for moderate and low-income families. The Action Ottawa plan refocuses emphasis on three established sectors, all which fall into the basket of the lowest income level Canadians. We will be returning to the impact of the City of Ottawa's housing policy later in this paper.

As previously mentioned, qualification for 'affordable housing' stock is based on income level. In the Ottawa area there is a centralized housing registry which keeps a running wait-list of those qualifying for affordable housing. There are three lists: General List, Housing for Seniors List, and a Supportive Housing List. With only 150 affordable units being added to the housing stock yearly in Ottawa, ${ }^{40}$ the waitlists are long, and waiting 6-8 years for a unit is not uncommon.

What is considered an 'affordable monthly rent' and an 'affordable dwelling price' for the City of Ottawa is outlined in a table of rents and housing prices. The table outlines the income percentile (based on statistics of median incomes in Ottawa) and the costs of housing considered affordable for that percentile. At the 30 percentile, household income is $\$ 54,600$; for this income level, affordable rent is considered to be $\$ 1366$ a month. At the 40 percentile, household income is $\$ 69,500$; for this income level, affordable ownership is considered to be $\$ 273,000$. Any costing over these rents and sale prices are considered over 'affordable housing' rates for these income levels. ${ }^{41}$

The reality is that the issue of 'housing affordability' relates to every person (regardless of income level). No matter what a person's, or household's, income is, if the household is

\footnotetext{
${ }^{39}$ Action Ottawa: Affordable Housing Initiative, Program Guidelines 2003 http://ottawa.ca/calendar/ottawa/citycouncil/hrssc/2003/09-04/ACS2003-PEO-HOU-0004\%20Attachment\%201.htm https://ottawa.ca/en/residents/social-services/housing/affordable-housing

"Action Ottawa combines City incentives with funding from all three levels of government to assist private and non-profit developers in building new affordable rental housing for moderate and low-income households. Action Ottawa bundles fee relief and capital grants and in some cases City-owned land. The overall objective of Action Ottawa is to support the creation of needed affordable housing by making available significant municipal resources and facilitating access to programs provided by other levels of government."

${ }^{40}$ Interview with Saide Sayah. Pg. 160.

${ }^{41}$ Hussey, Graeme. Presentation to Convivium: Social Purpose Real Estate Development. Jan. 24, 2018.
} 
spending over $30 \%$ of their income on housing costs, their housing is not 'affordable' relative to their income level. Many in Canada at the moment are over-extended, spending more than $30 \%$ of their income to carry their mortgage debts.

Review of the recently released National Housing Strategy (Nov. 2017) reveals a continued emphasis on "affordable housing" as social housing for those in the greatest need, and shows little innovation regarding other sectors of the population, or housing typologies. Although commendable, the strategy doesn't even begin to address the diversity of social and human issues that housing the elderly entails.

\subsection{The New Housing Crisis: Housing Affordability}

Former Chief Planner of the City of Toronto, Jennifer Keesmaat, stated in a recent CBC Business interview, "It used to be that when we talked about affordable housing we actually worried about social housing...really what we are talking about today is people who are able to be fully employed, but are not able to afford housing. That is a whole new problem." 42

This statement, speaking to the issue of housing affordability, has much wider implications. In Canada's largest metropolitan areas, housing options for the moderate-income earner (and those on fixed incomes) have come down to a choice between buying a small condo or renting an apartment. The prices for these are now outside the price range of most working adults and certainly outside the range of most seniors. Alternative housing types that address the needs of the moderate-income earner need to be considered, and amongst the options is the cohousing community.

Katie McCamant, of Cohousing Development Consulting, stated in her interview with me that: "the big issue in the U.S. housing market right now is that new housing is out of reach for a huge portion of middle and moderate-income families, I don't have a solution for that." ${ }^{\prime 3}$ She continued by contextualizing the issues of affordability that cohousing struggle with, to the larger context of the housing affordability crisis in the USA, "This is not just a cohousing issue,

\footnotetext{
${ }^{42}$ Quote by Jennifer Keesmaat. CBC Business News with Jacqueline Hansen. “Ultra-low rental vacancy rates highlight 'desperate' struggle to find affordable housing". Posted: November 29th 2017.

${ }^{43}$ Interview with Katie McCamant. Pg. 193.
} 
but a housing issue. ${ }^{\prime 44}$ I would expand the scope of her comment to cover the cost of new housing in the Canadian context, particularly in metropolitan areas.

The federal, provincial and municipal governments" continued focus on those "most in need" is a moral necessity given the limited funds allocated to housing programs, but innovative strategies to address other sectors of the population would add a significant dimension to policy planning. A broader and more holistic view, on the impacts of alternative means of housing the elderly (and others), would reveal opportunities for savings in a number of important sectors of fiscal spending.

\subsection{Cohousing Benefits to Health and Health Budgets}

The health-care costs incurred by seniors is staggering. In 2014, the last year for which agespecific health spending data is available, seniors aged 65 years and older constituted about 16 percent of the population, ${ }^{45}$ but consumed "almost $46 \%$ of all public-sector health care dollars spent by provinces and territories" (ClHI, 2016). The savings potential of cohousing models for the economics of senior health-care is equally impressive. Cohousing consultants ${ }^{46}$ claim that one senior, living in a cohousing community instead of a government funded care facility, saves the health-care system $\$ 40,000$ per year. If we accept the estimates that seniors living in cohousing can 'age in place' for 8-10 years longer than if they were living in their own home ${ }^{47}$, the savings are significant. The 'community of care' environment of cohousing means that many of the services now provided by the government and private agencies are offered by residents to one another.

In addition, by living in a community environment many of the mental and physical health risks associated with isolation are mitigated. Social issues that include: effects on family cohesion

\footnotetext{
${ }^{44}$ Interview with Katie McCamant. Pg. 189.

${ }^{45}$ Bacchus Barua, Milagros Palacios, and Joel Emes (2017). The Sustainability of Health Care Spending in Canada 2017. Fraser Institute. <http://www. fraserinstitute.org> and Canadian Institute for Health Information [ClHI] (2016). National Health Expenditure Trends, 1975 to 2016. Canadian Institute for Health Information.

${ }^{46}$ Shelley Raymond of Solterra In-Home Support Services (SISS) http://solterraco-housing.com

${ }^{47}$ This is the time frame that a senior can remain 'aging in place' in a cohousing community, over staying in their private residence.
} 
related to the stress of older family members on family caregivers; the added financial stress of covering the costs of private old-age residences and in-home services, can be addressed by living in a community environment. The analysis of transportation issues could also reveal the potential benefits of communal living: ride sharing, fewer cars and therefore less carbon emissions. The needs of seniors who can no longer drive require rethinking some of our current transportation systems. Ultimately both, the financial health of our economy, and the wellbeing of our population stand to benefit from supporting the cohousing model as an alternative housing strategy for aging adults.

\subsection{Financial Strategies for Creating more 'affordable' Units in Cohousing}

Returning to the cohousing challenge of incorporating units that are affordable to the low-to moderate income resident. In January 2010, the Cohousing Association of the United (CohoUS) initiated a study on the inclusion of affordable units within cohousing projects. ${ }^{48}$ An equivalent study does not exist in Canada, but the findings and the recommendations for the American context speak to the same issues that Canadian cohousing projects face.

The study set out to outline strategies that could be employed to accomplish the goal of including 'affordable units' in cohousing projects. It describes a variety of public and private subsidies, which might enable cohousing groups to financially integrate affordable housing units in rental and homeownership cohousing structures. As many government subsidies are only available through competitive application processes, the task force recommended that

\footnotetext{
48 "Affordable Cohousing Toolkit: A Summary of Public and Private Affordable Housing Programs" by Affordable Cohousing Task Group. The Cohousing Association of the U.S., June 2010

The US task force reported that of the 79 respondents (a total of 120 cohousing projects existed in the country at that time), only one third had been able to incorporate affordable units. The report also noted that one third of the respondents (surveyed communities) used private resources to help make some units affordable, some relying solely on members as their sources. Only 10 of the 79 communities used public funding; whereas 5 combined both public and private. The total number of "affordable" units for all 79 communities reporting was 181 units. Public programs subsidized 94 of these units; however, 61 of these 94 were completely in two developments (Elderspirit, Abington, VA and Petaluma Avenue Homes, Sebastopol, CA). Subtracting these units from the total number leaves only 33 units that were publicly subsidized in the other 77 communities. A total of 87 units were made affordable with private resources, or two and a half times the number benefiting from public subsidies for home ownership. In some cases, both public and private subsidies were employed in the same community. These figures clearly indicate a need for more public resources to make cohousing more affordable.
} 
Cohousing groups consider partnering strategies, for example, with local non-profits, with experience in these competitive applications.

Chris Scott-Hansen, cohousing development consultant and principal at Urban Cohousing Associates, describes similar strategies on his website. ${ }^{49}$ According to Scott-Hansen, most effective affordability strategies rely on the trust that had been created in the interpersonal relationships within the community. These arrangements are based in what he calls, 'internal banking $^{50}$ mechanisms, and enable those with limited resources to get assistance from members with greater financial capacity. The strategy best suited to a particular community depends on the level of trust, the liquidity of assets, the willingness of participants to take financial risk, and the timeline necessary to meet financial deadlines. ${ }^{51}$

The approaches outlined by Chris Scott-Hansen, as well as those outlined in the Affordable Cohousing Toolkit report of April 2016, 52 include both internal and external funding sources. The modes of internal funding support for members are easily transferable to the Canadian context, whereas the external sources (public funding and private investors) are somewhat specific to the American context and would require further research, which is outside the scope of this thesis, to clarify their similarities and differences to the Canadian context. In general, however, the larger categories still apply to us here in Canada:

1. Internal down payment assistance (members operate as financers)

2. Outside down payment assistance

3. Second mortgages (member to member loan)

4. Co-purchase options

5. First time buyers

6. The reduced monthly condo fee subsidy

\footnotetext{
${ }^{49}$ Chris Scott-Hansen: Principal at Urban Cohousing Associates, is a respected leader in cohousing development in North America and author of The Cohousing Handbook: Building a Place for Community. Chris has assisted more than 35 cohousing groups across North America with all aspects of the cohousing development process from land acquisition to construction. He is based out of Washington State.

50 Urban Cohousing Associates. http://www.urbancohousingassociates.com/resources/affordable-cohousing/

${ }^{51}$ Chris Scott-Hansen, "Creating More Affordability in Your Community: A Selection of Ideas," Urban Cohousing Associates, Inc., 2015, www.urbancohousingassociates.com. www.cohousing.org/node/2977 (accessed March, 2018)

52 "Affordable Cohousing Toolkit: A Summary of Public and Private Affordable Housing Programs Affordable by Cohousing Task Group". The Cohousing Association of the U.S. June 2010.

http://www.cohousing.org/sites/default/files/attachments/affordable summary.pdf
} 


\section{Maintenance reserve reinvestment}

8. Unit price buy down

9. Design for affordability - capital costs and operating costs

10. Shared units

11. Community owned rental unit

12. Participating non-resident owners

13. Purchase of one or more units by an outside affordable housing entity ${ }^{53}$

\subsection{The Affordability Challenge within Convivium}

Statistics analyzing the ratio of lower and middle-income seniors to upper-income seniors interested in participating in cohousing, do not exist for the Canadian context. ${ }^{54}$ However, if we are to take the Convivium experience as any indication, persons who first show interest in a cohousing project represent a greater diversity of income levels than those who are ultimately able to continue in the process.

The original breakdown of people interested in Convivium (and IHOA) who were unable to move forward for lack of financial capacity, is significant. Of the original group gathered under the IHOA banner, $1 / 4$ to $1 / 3$ were low to moderate income seniors. Many of these were single women, who were either widowed, or divorced, and living on fixed incomes. These women were living in small to moderate size homes that represented their primary asset, or alternatively were renting a housing unit.

Their assets could not produce enough capital to invest in the cost of a cohousing unit especially with the required up-front funding of a self-financed project (we will address this issue later). Not only could they not afford the cost of a unit, but they would not qualify for a mortgage at any bank given the risks in developing a cohousing project. There were also, both women and men, who expressed a desire to rent rather than to buy at this stage in their lives, in order to retain some financial capacity to meet unexpected medical and health-care expenses.

\footnotetext{
53 Scott-Hansen, "Creating More Affordability...". www.cohousing.org/node/2977

54 The terms lower, middle and upper-income relate to terminology used in describing which income tax bracket a person falls within.
} 
Some of the seniors who could not afford the price of a cohousing unit might have qualified for "affordable housing," or government housing subsidies; if an affordable housing unit had existed within the cohousing project, they would have qualified to live in it. Given the length of wait-times for those on the Housing Registry in Ottawa, and the limited number of units available to those on the lists, it would be a step in the right direction for the government policy to extend the financing of 'affordable units' to include them in self-organized communities. This would help to facilitate cohousing communities to incorporate members from lower and middle-income levels in their projects.

The way in which the housing lists are currently managed, even if the cohousing group was able to find the financing to build a number of "affordable units", or the City was to fund some units within market-rate housing projects, the community would not be in a position to choose its own cohousing members off the wait list to live in those units. Affordable housing providers are presently bound to accept the person at the top of the wait-list who had no previous relationship to the cohousing project, and may not be interested in community living.

\subsection{Commentary}

One of the central challenges facing all cohousing projects is the inclusivity of different income levels. This challenge is exacerbated by the usual choice of ownership model over a rental. The financing structure and the cash-flow timeline of the ownership model makes it difficult for a cohousing group to set up the private financing necessary. Financial institutions are used to funding developers who have the backing of investors and are, understandably, risk averse.

The necessity for potential cohousing residents to find the mechanisms to be able to put money "up-front" in the development process is a considerable impediment for most groups. In the more common scenarios of buying a developer-built condo, or home, one is only required to come up with the financing after the unit is constructed; in the cohousing scenario, the potential residents are operating as their own developers and must cover all the initial costs. In this scenario, the question of how to finance the ownership of an additional unit that could be 
rented to the low-income person, remains challenging. Most cohousing groups do not have the money to invest in an additional unit for another member to rent.

An additional complication of the current urban-housing market is that when the numbers are run to determine the amount of rent that would be required to cover the costs of mortgaging the unit, if the cohousing group were to finance additional units for rent, the rent would be higher than the average market-rent for the same size unit. This situation is a result of the high cost of urban land and new-construction, which drive up the per sq. ft. cost of the unit and thus the rental price.

There is currently no easy mechanism to obtain government funding to build an affordable rental unit in a housing project that is not built and financed by government money (eg. by Ottawa Community Housing Corporation $(\mathrm{OCH})$ or Centertown Citizens Ottawa Corporation (CCOC) in Ottawa). The provincial government will finance, for example, 40 units of affordable rental in a co-operative, or non-profit housing project, but it will not fund 5-10 units of affordable rental units in a 25 to 40 -unit cohousing project. A minimal subsidy of $\$ 100,000$ per unit is available, but this does not begin to cover the costs to the community of financing an additional unit in the project. If the government funding that is available for building new affordable units by $\mathrm{OCH}$ and $\mathrm{CCOC}$ was also available to cohousing projects, the possibilities might be different. 
INTER-LOGUE

convivum cohousing for Seniors

Log Entry

Ottawa, Ontario

January 22, 2018: Received Basecamp notification for a message concerning one of the sites that the convivium Land Acquisition Group (LAG) have been looking at. LAG has done a great job of documenting the sites that our real-estate agent has been investigating. The 'Hey! Box' notification states that the site in New Edinburgh. is active; the owner has been contacted and is showing interest. A decision must be made very quickly as to whether we are interested in pursuing this opportunity. A skype call is organized for 6:00pm the next day to bring together all equity members at short notice.

January 23, 2018; 6:00pm: We are a group of seniors ranging in age from 55 to 85, so our literacy around computer technology is very limited. Despite this, we manage to get 11 of us on the call, some of whom are calling in from victoria. None of us want to be seen by each other, so we skype with just our voices. The discussion centers around whether or not there is enough interest in pursuing the site and what our next steps should be. It sounds as if everyone is interested in this location and the possibility of another turnkey project. This would be the second turnkey project in which we have attempted to partner with a developer; the first was with the Regional Group for a building on the new Greystone site. Unfortunately, that opportunity did not materialize into a sale, primarily because the size was larger than our cohousing group needed.

we feel emboldened this time as we now have some experience with this kind of a partnership. That is almost 2 years ago now, and we believe that we are in a better position to know how to proceed. An inperson meeting is scheduled for two days later; we will meet on wednesday, Jan 24th at 5:30pm before our scheduled meeting with Graeme Hussey, president of cahdoo. We need to gange our financial capacity to buy the land and the developer's design plans. We have already agreed that we are not in a position to make an offer to buy the entire building. We will meet with Graeme at 7:0opm so we have an hour and a half to come to a decision.

january 24, 2018; 5:30pm: We are gathered at cahdoo headquarters, currently located on the first floor of the Beaver Barracks project on catherine St. Beaver Barracks is a non-for-profit affordable housing project developed by ccoc over a five-year period (1995-2000?), and, is for the moment, the largest affordable housing project ever built in canada. convivium has organized for Graeme Hussey to give us a presentation regarding the kind of services that cahdoo could offer us. Perhaps the most consistent message we have received from others who have attempted a cohousing project is that it is crucial that we hire a development consultant, better still, a cohousing development consultant. There is no one in eastern canada, so, we have approached cahdoo which seems to offer similar services.

We meet regarding the site in New Edinburgh; it becomes obvious that we are not yet in a position to offer the developer a guarantee of our financial viability. My interviews have underscored the importance of such a financial plan to give a developer the confidence that we would be a good development partner. Others in the group are interested in discussing the details of the architect's plans and whether or not they meet our needs. To me this foous on details feels premature; we need 
to be focusing on the bigger issue of financial feasibility. The Finance and ownership committee have determined the amount each of us would need to deposit with an 'offer to purchase' and for a down payment on the land, but many of the expenses that will follow feel, as of now, uncertain.

It appears that of the 14 equity member households present, as well as for those members present that are not equity members (general members) the interest is high; by far, the majority would like to proceed in showing interest in the project. The real estate agent has already spoken with the developer and owner of the property, who has offered to get back to us in a week.

7:0opm: Some of us brought dinner with us; others brought a soup from Loblaws, where most of us parked and someone has brought brownies for all of us to eat. The time that we have to discuss the site is over, and Graeme Hussey ushers us in to the adjacent room for his presentation. I have already met with Graeme; I did an interview in November with him and recommended to convivium that we set up this meeting. I have reviewed his interview in the last week so as to be prepared to ask pertinent questions. Graeme gives his presentation covering cahdoo, ccoc and the services that they provide. He is emphasizing the importance of doing the groundwork for the project in terms of budgeting and cost analysis. He feels that it is premature for us to be looking for a site before we have done this financial planning or 'pro forma'. I'm not sure that those in our group are actually hearing the importance of this step; it seems to me that many in the group believe that we have done a lot of the necessary work, but it is also clear that many feel that, "we cannot know what we don't know", and that Graeme has far greater experience in the development process than all of us put together.

In the interviews that 1 conducted, there was unanimous agreement that the most challenging aspect of creating a cohousing project is the complexity of the development process and the lack of development expertise. No one in a cohousing group could possibly be expected to have this knowledge. The recommendation has been to hire a cohousing consultant, and it appears that cahdoo might be in a position to offer the development expertise we need. We have contracted cahdoo for specific tasks to date, but we desperately need a captain to guide our ship.

9:00pm: The meeting ends, and 1 am anxious to do a debriefing, but others need to get home. We decide that we will discuss further at our board meeting, which we are now calling the coordinating committee in alignment with the consensus model that we have decided to adopt. Recommendations will then be discussed at our next equity member meeting on February 6. Some members of LAG are concerned that the developer may have other offers on the table, and that that is why he is delaying his response till next weel. We all head out into the cold january night in ottawa to find our cars and head home. 
Part 03

\section{The Complex Nature of the Development Process}

"What is the most challenging aspect of creating a cohousing project?" The most consistent response given by sector experts to this question is that the complexity of the development process is the largest obstacle to success. To unpack what this means we have to keep in mind that the members of a group wanting to create a cohousing project are not development experts, nor are they an experienced commercial client, or land owner who has an established network of professionals.

\subsection{A Crucial Role: (Cohousing?) Development Consultant}

Katie McCamant, Architect and co-author of Creating Cohousing ${ }^{55}$ stated in her interview with the author of this thesis, "Cohousing people don't want to become real-estate developers, but they need to learn about what it takes for a real-estate development to be successful." This is a tall order! How they learn about 'what it takes' can determine whether their project flounders, or stays afloat. If they attempt to learn the ropes of real-estate development through their own research, they are unlikely to succeed. The need for a development consultant familiar with the development process, ideally with cohousing development, is central to their success.

Those interviewed with previous experience in the development of cohousing projects - from architects to developers, from residents of completed projects to consultants - recommend that potential cohousing residents hire a cohousing development consultant. The most important role that the consultant will play is to help develop a professional partnership between the developer and a cohousing group. Cohousing development consultants are experts trained in a wide spectrum of skills necessary to create a cohousing project; not least of which is the capacity to be the translator between the world of the developer and that of the cohousing group.

\footnotetext{
${ }^{55}$ McCamant and Durrett. Creating Cohousing: Building Sustainable Communities. 2011.
} 


\subsection{The Private Developer}

Most developers are not interested in the time and energy that is required to communicate, negotiate, and make decisions with a large group of adults inexperienced in the development process. Most are in the business of building to tight budgets, on a tight timeline, with the decisions and control being in their hands; they are in business to make a profit. Most developers are building projects designed for the 'no-name' client. The huge wave of condos that have been built over the last years are built and sold to clients that the developer will never know. Normally, developers do not have to deal with the idiosyncrasies of a real client, or group of clients in the case of cohousing, before the project goes to sale. A developer is not in the business of organizing a group of potential clients, nor working with a group of clients to make decisions. The cohousing group has to self-organize and take the responsibility of understanding the development process - but not without a consultant.

\subsection{Roles of the Cohousing Development Consultant}

Amongst other things, the cohousing development consultant has the difficult task of getting the group to understand the realities of what it will take to create their project; this includes building the budgets and investment structures so that the group can be a reliable and sound partner for the developer. In addition, the cohousing consultancy needs to take on the task of guiding the cohousing group in organizing themselves.

These two responsibilities are different in nature. A cohousing development consultant will often partner with others who can assist in some of the varied skills the cohousing group will need to develop. Ronaye Matthew, founder and principal of Cohousing Development Consulting out of $\mathrm{BC}$, has a number of colleagues who help with specific areas; for example, associate Margaret Critchlow offers workshops covering facilitation and consensus building. The cohousing development consultant also ensures that other experts that are required for the project are people who have an understanding of multi-family housing, the financial scope of the project and the programmatic requirements of a cohousing project. 
Building a healthy working group of adults is essential to the success of a cohousing project, both in the social and financial sense. Achieving a healthy and viable community is in itself a challenge.

\subsection{Cohousing Development Consultant versus Development Consultant}

There is a difference between the experience of a traditional development consultant and a cohousing development consultant. Most development consultants understand the development process of a built project, but are not familiar with working with a substantiallysized group of adults as their client. Most often, traditional development consultants work with owner/investor groups - organizations represented by Board Members who make important decisions as a unit; on the other hand, they may work with one owner, or an owner's representative. In either of these cases, they do not have to deal with a large group of clients.

Their lack of experience working with the complexities of group dynamics in a diverse group of adults, and a decision-making process that is non-hierarchical, places them at a disadvantage in supporting a cohousing group. A cohousing development consultant must know how to navigate, not only the building development process, but also the interpersonal dynamics of the group. It is one of their responsibilities to represent a consistent messaging in negotiations with builders and developers, to mitigate the difficulties of working with a large group of clients.

\subsection{Limited Availability of Cohousing Consultants}

The pool of cohousing development consultants in Canada and the USA is limited; this in itself, creates a challenge for groups interested in moving forward with a cohousing project. Currently, in Canada, there is only one full-time cohousing development consultant, Ronaye Matthew, of Cohousing Development Consulting working out of Burnaby BC. Ronaye is currently working simultaneously on four cohousing projects in British Columbia and cannot extend her consultation services outside of the province at this time. Lynn Hannley (The Communitas 
Group $)^{56}$, out of Alberta, has been working on developing cooperative housing since 1975, but has limited experience with the equity-coop cohousing model. She is responsible for managing the development of Prairie Sky (2003), Alberta's first cohousing community, but has not, to date, extended her consultancy outside of Alberta and Nunavut. This situation leaves groups in Eastern Canada with few options for cohousing development consultants.

There are other consultants in training, but many do not have a background in real-estate development, as both Ronaye Matthew and Lynn Hannley do. In Toronto, three men currently in training with Charles Durrett (Creating Cohousing ${ }^{57}$ and The Senior Cohousing Handbook) ${ }^{58}$ in the USA, held an information session about cohousing in January 2018. Mark Powell, Kristopher Stevens and Duncan Goheen have come together to create CoLiving Canada ${ }^{59}$ with the aim of promoting cohousing as a response to the needs of older adults. The collaboration of these three men is representative of the growing interest in cohousing and in training to facilitate cohousing projects (as differentiated from becoming a professional 'cohousing development consultant'). Architects Kathryn McCamant and Charles Durrett, authors of the definitive guides to developing cohousing, currently offer trainings to become cohousing facilitators through online webinars plus an in-person retreat in Nevada City, USA.

\subsection{The Cohousing Development Process}

As testified by many of the experts interviewed, the complex nature of the development process is a key factor in the demise of many cohousing groups. To understand this statement better, it is necessary to look closely at some of the aspects of the cohousing development process. The following table ${ }^{60}$ outlines some of the stages of the project that must be managed and financed, either by the developer (absorbed in their profit-margin), or by the cohousing group itself (if they are acting as their own developer):

\footnotetext{
${ }^{56}$ www.communitas.ca

${ }_{57}$ McCamant and Durrett. Creating Cohousing: Building Sustainable Communities. 2011.

58 Durrett. The Senior Cohousing Handbook: A Community Approach to Independent Living. 2009.

59 https://colivingcanada.com

60 Canada Mortgage and Housing Corporation (CMHC). Housing for Older Canadians: The Definitive Guide to the over 55 Market; Volume 3, Planning the Project. 2012.
} 
Phase 1: Initiation

Testing and redefining the development concept

Marketing the project

Designing the project

Determining organizational and legal considerations

Phase 2: Pre-construction

Community consultation and obtaining regulatory approvals

Arranging financing

Assembling and coordinating the project team

Choosing the project delivery approach

Phase 3: Construction

Phase 4: Turn-over
Entering into the construction contract

Constructing the project

Completing and turning over the project to the community

Part Four of this thesis, which follows, will focus on some of the more important steps of the development process that need to be in place if a project is to succeed. The tendency of most cohousing groups is to focus in on the details of a project, before understanding the bigger picture. The importance of grasping the financial demands of a cohousing project, the process for securing land, and the need for enough human capacity (members within the group able to accomplish the tasks necessary to move the project forward; and professionals external to the group to support the development process) cannot be overestimated. The feasibility of a project in all three of these areas must be analysed, and the project proven to be viable before financial institutions will help mortgage the project, or before developers will take the risks associated with building a housing project. 
Part 04

\section{Necessary Steps to Cohousing Success}

\subsection{Assessing the Feasibility of the Project - Land, Money, and Human Capacity}

Graeme Hussey, Director of Housing Development for CCOC and current President of Cahdco (the development arm of $\mathrm{CCOC}$ ) had the following observation in regard to most self-organized housing projects: "Most groups will start with doing all these surveys and come to us with, 'we want green sustainable housing; we want four floors with $50 \%$ one bedrooms and $25 \%$ two bedrooms; we want this specific amenity space', but they don't even know the business model. The business model is like a one-page pictogram of how things fit together; I like to call it the pro-forma. ${ }^{\prime \prime 1}$

The challenge of moving from aspiration to reality is one of the most difficult transitions for any cohousing group. The lack of understanding and expertise regarding the financial capacity needed to invest in a 20-30 unit building project and the implications of a time-line of financial investments (cash-flow), leaves projects stumbling for years. Financial modelling, or pro-forma, is specific to individual projects and depends upon the cost of the land acquired, the cash flow for the development model chosen, the interest rates of loans and type of loan, and whether a project will be an ownership or rental model. For these reasons, a financial study will not be pursued in this thesis. In the initial feasibility phase of the project, the group must assess what financial and human capacity they will require to realize their project, as well as determine the necessary site requirements that their project will require.

The feasibility stage of a project will clarify a number of different aspects: the vision of the group must be understood; the governance model, authority and decision-making structures need to be decided upon; roles and responsibilities need to be confirmed; contracts with consultants need to be defined and managed; legal reviews need to be coordinated; a preliminary 'pro forma' and financial analysis need to be undertaken; coordinating funding, or

\footnotetext{
${ }^{61}$ Interview with Graeme Hussey. Pg. 121.
} 
financing applications; liaison with the City of Ottawa Housing Services branch and Planning Department needs to be established. ${ }^{62}$

Graeme Hussey, clarified the three necessary components of every project feasibility study:

"We think of every project as needing three broad characteristics. Many groups jump right into details that fit into these three broad groups without knowing what those three things are: land, money and capacity... If you don't have land that works for your needs, if you don't have the money, and if you don't have the corporate capacity you can't do a project. You need to have these things - and it's not like you have to hit one, you have to check each of those - to have a feasible project." ${ }^{163}$

This statement gives indication of the complexity of developing a cohousing project. It also underlines the importance of the financial plan, land acquisition and the availability of human resources. The financial planning component of an urban cohousing project such as Convivium is complicated, but before the group can begin to determine its finance structure, it must decide on a legal structure for its housing as this will have implications for the financing of the project.

\subsection{Choosing a Legal Structure; Condo versus Co-op}

Establishing a legal and organizational structure as the foundation for negotiations with professionals (real-estate agents, lawyers, consultants and developers) is an important first step.

By far the largest percentage of cohousing projects in Canada and the USA choose to work with the condominium structure (condo); only on rare occasions does a cohousing group choose a cooperative (co-op) structure as in the case of Convivium Cohousing. The importance of the choice of legal tenure is that it will directly impact the funding of the project. To make such a decision the group must understand the implications of both forms of legal structure: the condo and the co-op.

\footnotetext{
${ }^{62}$ Cahdco. Schedule A: Project Management Services Agreement with Convivium Cohousing. Pg. 1\&2. 2018.

63 Interview with Graeme Hussey. Pg. 121,122.
} 
To begin we must bear in mind that most cooperatives in Canada are non-profit rental apartments that have been built with Federal subsidies (managed through the provinces). When a cohousing project is looking at residents owning shares of the building it is referred to as an equity co-op. In an equity co-op structure, all the project funding will need to come entirely from the future residents themselves.

Cohousing development consultants unanimously recommend that a group choose the condo model, ${ }^{64}$ not the co-op model; this is mostly because banks are unfamiliar with the cooperative structure and will not fund them. The cooperative model rests on an ownership structure where all members hold shares in the project, and banks would have to give 'share-loans' instead of mortgages. As of this time, there are no banks in Canada that offer share loans, although there are a few credit unions who have given loans to cohousing cooperatives.

According to Katie McCamant ${ }^{65}$ the sole-source financing that is likely in the case of a creditunion offering a share loan, is a risky proposition. In the USA, this statement may be particularly pertinent as the banking system is in constant flux, with some banks going out of business, and others being bought out. In Canada, this argument may not be as convincing. However, it is true that a single credit union supporting a project, in the present, does not guarantee financial support for future households wanting to buy shares from a previous owner (say 50 to 75 years down the road). That one credit union may not exist in 50 years, or it might no longer be willing to offer financing for shares in the co-op, as it did for the original owners. The other point to keep in mind with single-source financing is that residents will be paying non-competitive interest rates for their loans. Perhaps in time, banks may become comfortable enough with the cooperative model to provide share loans, thus creating a competitive interest rate market.

The strongest argument for choosing the cooperative model over the condo model has to do with the degree of control the share-holders have over who can buy into the project in the

\footnotetext{
${ }^{64}$ Interview with R. Matthew; Interview with K. McCamant.

${ }^{65}$ Interview with Katie McCamant. Pg. 190.
} 
future. With a condo structure the cohousing members have no legal right to choose who will buy a unit. With the co-op model, cohousing residents can use an interview process, community education workshops, institute guidelines in their bylaws for age preference, and select who they want to join their community. This advantage of the co-op model is not regarded as an issue by most cohousing that has gone the condo route; ${ }^{66}$ it seems that most condo units can be 'sold' through word of mouth to friends and like-minded people. However, in the legal sense, no selective process is allowed.

The other reason for selecting a cooperative cohousing model may be values based. Those interested in living in cohousing have a strong community orientation; the history of cooperatives as democratically governed by the residents themselves has appeal. The values and beliefs of cohousing groups align naturally with those of cooperatives.

\subsection{Choosing a Project Delivery Approach; Alternative Development Models}

Once the members of a cohousing group have decided on the legal structure of their future project they need to address the financial feasibility of the project. The selection of a 'project delivery approach' ${ }^{67}$, or development strategy, must be determined to finalize the financing of the project. Each development strategy has different implications for the financial structuring of the cohousing project and will substantially impact the financial feasibility for some members. This is largely the result of cost flow differences that require a larger up-front investment in certain approaches, combined with the fact that most people will need to sell their homes to have the capital to purchase unit shares.

This is not an easy decision; the cohousing group must be flexible enough to ride the waves of unforeseen opportunities, but also simultaneously pursue a clear direction. The ultimate

\footnotetext{
${ }^{66}$ Interview with K. McCamant. Pg. 191.

${ }^{67}$ Housing for Older Canadians. Volume 3, Planning the Project: The Definitive Guide to the Over-55 Market. CMHC Publications and Reports. 2012. \# 67662 https://www03.cmhc-

schl.gc.ca/catalog/productDetail.cfm?lang=en\&cat=178\&itm=185\&fr=1518811898151
} 
decision may be dictated by an opportunity that presents itself unexpectedly. The final choice of development strategy and its accompanying financial structure will determine whether a unit ends up being affordable, or not. 


\subsection{Case-Study: Choosing a Development Model for Convivium}

We can look at the case of Convivium to help us understand the different delivery approaches that can be considered.

The first opportunity that presented itself to Convivium was in the context of an urban development called Greystone, in Old Ottawa East, located off of Main St. The foundations of a relationship with the developer of Greystone, Regional Group, had been laid by the Old Ottawa East Community Association and. A group of interested residents gathered under the name, Innovative Housing for Older Adults (IHOA) in Old Ottawa East in 2015. The organization of the group was led by Rebecca Aird, a member of Terra Firma Cohousing in Ottawa, and chair of Sustainable Living Ottawa East (SLOE). Rebecca was a committed advocate for the group but did not put herself forward as a future resident. In fall of 2016 the group held a design workshop to brainstorm about possible sites and building types on the Greystone property. Around this time, the leadership of the group transitioned from Rebecca Aird, to Lynne Markell, a strong community advocate and past Manager of Co-operative Development for the Canadian Co-operative Association (2003-2013). Her leadership style was determined and committed, and the group felt in good hands. At this time the name 'Convivium' was offered by the members of a defunct cohousing group as it had already been incorporated and would save the current group time and money. This name has been adopted ever since.

After a number of attempts to partner with The Regional Group for a turnkey building, or to purchase property, were unsuccessful, Convivium decided to strike out on its own. The financial and organizational implications of Convivium becoming its own developer were staggering. The remaining choices, each with its own financial implications, were becoming clear: look for land to buy and then hire a design/build team; look for a developer who might already own land to partner with (as had Regional); find an existing building to renovate; or find some benevolent donor who would donate land for the cause. 
In the initial 'turnkey' approach offered to Convivium, the developer, Regional, would have played the following roles: owner of the land; builder of the project to the design specifications of its architect, Barry Hobin Architect; seller of the building to Convivium, once completed. In this kind of approach, the developer pays all the costs from the outset of the project and is paid in full by the cohousing group upon completion; in a modified turnkey approach the cohousing group would pay installments at certain agreed upon milestones throughout the development process. $^{68}$ All the risks are born by the developer, but the group pays an upcharge for the services and the financial risk that the developer is taking. This approach is attractive to a cohousing group who has limited real estate development experience. Nevertheless, it is important for the cohousing group to have an advocate who can represent their interests in the project design, development and construction (this could be an architect, or cohousing development consultant).

When Convivium made the decision not to accept Regional's offer, the group decided to put out an Expression of Interest (EOI) to local architects and developers. Cahdco was hired to manage the EOI and provide a financial analysis of the differential between Convivium hiring a developer or acting as their own developer. One of the stipulations of the EOI was that the groups showing interest needed to bring with them a piece of land. Of some 35 potential firms who received the invitation, only 3 responded. This was a great disappointment to the group, but it underscored the shortage of urban sites in Ottawa. Two of the three respondents had a site that they either owned or had a conditional offer on; the third expressed interest despite not having a site. Neither site was acceptable to Convivium, so the community decided to try a new strategy.

Had the EOI to find a developer, or architect with land, led to a desirable outcome, Convivium would have entered into an agreement, where, as the sponsor group, it would have hired the architect and paid for the design and construction of the project - as would any other nonprofit group in Ottawa wanting to build a housing project. Rather than a developer who would

\footnotetext{
${ }^{68}$ Housing for Older Canadians. Volume 3, Planning the Project: The Definitive Guide to the Over-55 Market. CMHC Publications and Reports. 2012. \# 67662

https://www03.cmhc-schl.gc.ca/catalog/productDetail.cfm?lang=en\&cat=178\&itm=185\&fr=1518811898151
} 
oversee the entire project, Convivium would take on more responsibility, both financially and organizationally. Essentially, in this scenario, Convivium would have operated as its own developer.

For Convivium (or any other cohousing group) the important difference in operating as its own developer versus working with an existing developer is largely in the pre-construction cash flow. As previously mentioned, in the private developer model, most of the financial risks would be taken by the developer himself; in the model where Convivium becomes its own developer, the group would have had to come up with all the money for the purchase of a site, the design fees for the Architect, the fees for project management, construction management and other consultants, the legal fees, and the site plan and building permit application fees. All before the building permit was approved. In a pre-construction cash flow analysis ${ }^{69}$ that was undertaken by a consultant on behalf of Convivium (if it were to develop its own 25-unit 3-4 storey wood frame building ) it was determined that the community group would have to come up with a monthly outlay of somewhere in the range of $\$ 45,000$ for each of the first 8 months, another $\$ 600,000$ somewhere around the $9^{\text {th }}$ or $10^{\text {th }}$ month and another $\$ 45,000$ for the last two months - all prior to building permit approval; for a total of over $\$ 1,000,000$. This estimate did not include the financing (down payment and loans) on the cost of land, which was expected to sell for around $\$ 2,000,000$.

In addition, in the model of Convivium as developer, the group would be responsible for any cost overruns, as well as any change orders for things that had not been included in the construction drawings (including changes resulting from unforeseen conditions or events) ${ }^{70}$. This option is likely to fail if the group does not hire a development consultant ${ }^{71}$ to oversee the process and represent their interests.

When the expression of interest failed to produce a team with a viable site, Convivium decided to employ a commercial real estate agent to help find a piece of land. It also formed a working

\footnotetext{
${ }^{69}$ Dennis Carr (Consultant with Cahdco). Pre-Construction Cash-Flow Analysis. 2017.

${ }^{70}$ Housing for Older Canadians. Volume 3, Planning the Project: The Definitive Guide to the Over-55 Market. CMHC Publications and Reports. 2012. \# 67662

${ }^{71}$ Interview with K. McCamant. Interview with R. Matthew.
} 
group called the Land Acquisition Group (LAG) to plan the process and develop a budget. LAG helped identify the need for a deposit and down payment on a potential property. Identifying this financial need, LAG also recommended the establishment of an equity membership within Convivium to help raise the needed funds. The cohousing group also retained an architectural firm to look at the feasibility of the site for the proposed project size and building type, as well as manage any site investigations required (e.g. soils tests, flood plain boundaries, infrastructure requirements, etc.). The idea was that after securing a site, the group would put out an RFP to qualified architectural firms to design and build the project. This approach resembles a 'pre-qualified tender' approach in which the architect remains the overall project lead and maintains responsibility for assessing the tenders received, making recommendations to the cohousing group for awarding the contract. ${ }^{72}$ Payment for services would be required on a schedule based on the of completion of project milestones.

\subsection{The Challenge of Finding and Securing a Site}

The challenges of finding land in an urban environment such as Ottawa, are numerous. Not only is land scarce, but for this reason, it is very expensive. Most private (for-profit) developers will adjust the size (number of storeys) of their project to bring the per-unit costs down and their profit margins up. For a cohousing group wanting to maintain the size of a workable community, the option of building 6-8 storeys (70-100 units) is not a viable alternative. Cohousing communities optimally range in size from 25-30 units, so if the land price is divided by that number of households rather than 100 units, the price of the land over fewer units leads to increased unit price.

In addition, in Ottawa, as in many other metropolitan areas, many sites are bought and sold under the radar; they will never be listed on MLS (Multiple Listing Service) websites. Developers have an inside track on available pieces of property and are not inclined to share their knowledge. Another challenge in the current market conditions is that competition to buy property is fierce; if a group cannot move fast enough, it may miss out on a sale. A third

\footnotetext{
${ }^{72}$ Housing for Older Canadians. Volume 3, Planning the Project: The Definitive Guide to the Over-55 Market. CMHC Publications and Reports. 2012. \# 67662
} 
mitigating factor in the Ottawa environment is that the City of Ottawa, the NCC, and the Federal Government have ownership rights over large desirable tracts of land, most often deciding to sell them to developers with proven track records ${ }^{73}$.

If Convivium were to end up buying land as a first step in its development process, the organization would need a mortgage to carry the costs of the property until the project was completed. According to a commercial lender with Desjardins Credit Union, Convivium would have to come up with $50 \%$ of the cost of the land, to be eligible for a mortgage on the remainder of the sale price of the land. Later in the development of the project, most members would need to sell their homes to pay for their units (or unit shares). Current equity members have agreed, in a Terms and Conditions document, that they would get home equity loans to cover the time from the start of the project to their move-in. For some households in the community, this may be a difficult financial arrangement to meet while they are still living in their homes. In a turnkey arrangement, this initial outlay of money for the land would not be required as the developer would be carrying the cost of the land until the 'sale' of the unit. However, a smaller amount would be required as a down payment to the developer.

At the time of this writing, Convivium was exploring another turnkey opportunity that had manifested. A desirable site was found, and the owner of the site - a developer who already had design drawings for an apartment rental complex - was considering the proposition of selling the building to Convivium for its cohousing project. For the developer this could save the costs of marketing the units. On the other hand, working with a group of potential residents and their programmatic requirements could add frustration and additional time demands.

\footnotetext{
73 e.g. lands for the Lebreton Flats development; Windmill's Ziji project on Victoria Island; Gladstone Village Site; Preston and Gladstone site.
} 
Part 05

\section{Housing Policy: Municipal, Provincial and Federal}

\subsection{The Politics of Housing}

In attempting to define the challenges of creating a cohousing project it is important to look at the broader context of government policy and planning. To understand the role that policy plays in addressing housing issues in Canada (and specifically in Ontario and Ottawa), we need to begin by reviewing the governmental structures responsible for housing policy in Canada, and the policy priorities of current and past governments. Only by recognizing current programs and policies can we point to possible strategies that might support a cohousing project.

To orient ourselves, a brief summary of the departments responsible for housing policy at different levels of government, and their respective department heads, is shown below:

Federal Level: Department of Employment and Social Development Canada

Minister of Families, Children and Social Development

Minister also responsible for $\mathrm{CMHC}$

The Honourable Jean-Yves Duclos

Provincial Level: Ontario Ministry of Housing

Minister of Housing and Minister responsible for Poverty Reduction Strategy

Hon. Peter Z. Milczyn

Municipal Level: City of Ottawa

Community and Social Services Department

Housing Services Branch

Affordable Housing Unit

Program Manager: Saide Sayah (2009-present)

\subsection{The Social Housing (affordable rental housing) Priority}

In looking at the naming of the housing departments, one of the things that becomes evident is the close connection in Canadian Housing Policy between the social services sector and the housing sector. This association reveals the direction that housing policy has taken in Canada. 
Even in the Federal Government's recently released National Housing Strategy (Nov. 22, 2017), ${ }^{74}$ the priorities remain unchanged. The emphasis on reducing homelessness and improving the availability and quality of housing for Canadians in need, dominates housing policy at the Federal, Provincial and Municipal levels.

Municipalities and social-housing advocates have urged governments to continue to focus on the housing needs of the lowest-income Canadians. Despite this focus, there is a failure of governments to dedicate the needed finances to meet these housing needs. Importantly for our discussion, current housing needs for other sectors of the population are not being addressed. $^{75}$

The Macdonald-Laurier report, A Home to Call Our Own: A Federal Strategy for Affordable and Responsible Homeownership ${ }^{76}$, notes that while the issue of social, or affordable rental housing is important, it represents only 6 per cent of the housing market. ${ }^{77}$ Sean Speer, Munk Senior Fellow, and co-author of the Macdonald-Laurier report, writes in a special report to Post Media:

"Where the strategy is notably lacking is with regards to housing affordability in the market-based share of the housing market. It's an odd omission for several reasons: housing affordability has recently hit its worst levels in a quarter century; market-based housing affects more than 90 percent of the market; and the federal government touches on it - from mortgage insurance to financial regulations to the tax system." ${ }^{78}$

\subsection{Funding Sources and Allocation}

To better understand how the politics of housing are determined and what factors are contributing to these decisions, I interviewed Saide Sayah, Program Manager of the Affordable

\footnotetext{
${ }^{74}$ Canada's National Housing Strategy: A Place to Call Home. Government of Canada. Nov. 22, 2017. https://www.placetocallhome.ca/pdfs/Canada-National-Housing-Strategy.pdf

${ }^{75}$ Speer, Sean. "Federal Housing Strategy ignores market-based issues". Special to Postmedia Network. Nov. 24, 2017

${ }^{76}$ Speer and Londerville. A Home to Call Our Own: A Federal Strategy for Affordable and Responsible Homeownership. A Macdonald-Laurier Institute Publication, Nov. 2017. https://macdonaldlaurier.ca/files/pdf/MLI FederalHousing webF.pdf

${ }^{77}$ Curry, Bill (Parliamentary Reporter, Ottawa). National Housing Strategy: "Ottawa to offer direct subsidies to low-income tenants". Globe and Mail, Nov.22, 2017. https://www.theglobeandmail.com/news/politics/expanded-national-housingstrategy-to-include-new-rent-subsidies/article37046894/

${ }^{78}$ Speer, Sean. "Federal Housing Strategy ignores market-based issues". Special to Postmedia Network. Nov. 24, 2017
} 
Housing Unit of the City of Ottawa. His long tenure with the City of Ottawa Housing Services Branch and his background in urban planning placed him in a unique position to answer pertinent questions about housing policy.

Several things became evident in the interview. Firstly, most of the funding for housing programs at the municipal level is federal money; as such, the federal government determines policy priorities by the allocation of its resources. As the priorities of the recently released National Housing Strategy, outlined above, indicate, the priorities of this government remain homelessness and social housing. Federal housing funds are divided amongst the provinces and territories, who then, in accordance with federal allocations, direct money and determine policy direction for the municipalities.

According to Mr. Sayah, Ontario municipalities come together to lobby the provincial government on behalf of their common ground: "we work very closely with Toronto, Peel, London, Hamilton, Durham region, all those; a lot of the cities around the GTA. Even the ones here, like Leeds, Grenville, it's quite a network, and we all work together. We've got different issues that we're all facing but we all have input and we try to have a collaborative voice going into the federal government. ${ }^{\prime 79}$ The federal government and the provincial government tend to vie for who will have most influence over city policy, but ultimately, the city is the creature of the province; they are directly under provincial jurisdiction. ${ }^{80}$

Secondly, the availability of federal funding has been a determining factor in creating programs. This availability is determined by a number of elements ranging from the state of the economy, budget deficits and which political party is in power. A good example of cyclical nature of political will was the withdrawal of funding for social housing projects by the Conservative government under Mike Harris (1995-2001) after a period of investment in affordable housing under the NDP government of Bob Rae (1990-1995) and Liberal leader David Peterson (19851990). ${ }^{81}$

\footnotetext{
${ }^{79}$ Saide Sayah, Program Manager, Affordable Housing Unit, personal interview with the author, Nov. 15, 2017. Pg. 175.

${ }^{80}$ Interview with S. Sayah. Pg. 186.

${ }^{81}$ Interview with Jamey Burr. Pg. 133-138.
} 
Thirdly, funding flowing through the province to the City of Ottawa has been cut back. Limited government funding for new programs has dictated that the City focus on those most in need. In any given year, the City of Ottawa only has the capacity to build 100-200 affordable units. Mr. Sayah spoke to current priorities: "The highest priority for the City of Ottawa has been housing homeless families. I think from my interactions with the province, our focus at the city level is a little bit different when it comes to affordable housing. It's not that there isn't a need for affordable housing for seniors; I just wanted to stress that we do have other priorities competing at the same time. ${ }^{82}$

According to Saide Sayah, only $20 \%$ of those on the centralized wait list for Ottawa are lowincome seniors. ${ }^{83}$ In addition, seniors on the wait list are housed faster than other groups. From a development perspective, seniors' buildings are the easiest of affordable housing buildings to place in communities - the least likely to experience the NIMBY (not in my back yard) response from neighbours. The City has been seeing an increase in seniors seeking affordable housing over the last years; this is in contrast to 10 years ago when the City was having difficulty filing space within its senior buildings. ${ }^{84}$ Despite this, seniors are not perceived as the group with the greatest need, and therefore are not seen as a top priority when it comes to housing policy.

\section{4 'Aging-in-Place': A New Policy Direction}

The current emphasis in senior housing policy is being placed on helping seniors 'age-in-place'. According to Mr. Sayah, city forums have shown that most seniors want to age at home. ${ }^{85}$ For this reason, provincial funds have been channelled toward programs that help seniors to achieve this goal. A partnership with the Champlain Local Health Integration Network (LHIN) offers seniors limited in-home care, the Ontario Renovates Program subsidizes accessible upgrades $^{86}$, and 'visitable' housing ensures grade access to units. The City is continuing to look for new ways to bring health services to seniors in their communities.

\footnotetext{
${ }^{82}$ Interview with S. Sayah. Pg. 156.

${ }^{83}$ Interview with S. Sayah. Pg. 160. (Mr. Sayah has direct access to these lists)

${ }^{84}$ Interview with S. Sayah. Pg. 160.

${ }^{85}$ Interview with S. Sayah. Pg. 159.

${ }^{86}$ Ontario Renovates Program, City of Ottawa. https://ottawa.ca/en/residents/social-services/housing/ontario-renovatesprogram
} 
The notion of 'aging-in-place' deserves attention. The current understanding of 'aging-in-place' assumes that the 'place' is home, and that 'home' is your family home (or the home you have been living in for the last 10-30 years). The realities of the move toward facilitating seniors to stay in their home, often results in the senior living alone, in a home that is over-sized for their needs, with inadequate support. The reality of 'aging-at-home' is likely to include the rotation of different care-givers (strangers to the senior), employed by a private health-care company that has been contracted by the local health-care network. These 'personal support workers' (PSWs) enter the home for time-limited visits (usually 45 minutes) to attend to a senior's personal care. They are overworked and underpaid, often rushed and stressed out.

The understanding of 'aging-in-place' needs to be re-examined to include the possibility that the 'place' can be a 'home' within a 'community-of-care'; that 'aging-in-place' can be aging in an environment that feels like a home - a private space where you still have your dignity and independence.; the 'place' in 'aging-in-place' does not have to be the physical home of your past. The conclusion that seniors prefer to 'age-in-place' should not be taken for granted as a singular answer valid for all seniors. The current preference for where a senior wants to age is worth inquiry, despite this falling outside the scope of this thesis.

'Why' seniors prefer to age in their home, is an important follow-up question. Speculating on the motivation of seniors to 'age-in-place' might include: the current inflated costs of living in a senior residence; the desire to remain in one's own neighbourhood close to friends and familiar amenities; the loss of a sense of autonomy and independence in moving into an institutional setting. The current direction of policy that justifies itself around the desire of seniors to 'agein-place', does not consider the social needs of seniors, their isolation and their loss of community connection. If offered the alternative of a cohousing 'community-of-care', the answer to the question of where and how seniors would like to age, might be different 
Part Six

\title{
Hurdles and Potential Development Opportunities from a City of Ottawa Perspective (for a Senior Cohousing Project)
}

\subsection{Perceived Risks: A City of Ottawa Perspective}

The interview with Mr. Saide Sayah, Program Manager of the Affordable Housing Unit in the Housing Services Branch of the City of Ottawa, revealed a number of unexpected hurdles for the potential of a cohousing project in the Ottawa area. These hurdles were discussed in relation to the possibility of the City of Ottawa supporting such a project, but they underscore the issues that would be faced by any senior cohousing project attempting to self-organize and self-finance in Ottawa.

\begin{abstract}
"It's challenging to bring a group together in an urban setting to be able to finance a cohousing project...there's so much cost involved in just getting land ready for development and starting construction. (If the City were to be involved $)^{87}$ we would need to do all the studies and get through the approvals to get a building permit; just for the initial start-up funding you'd be pushing $\$ 1$ million to get everything organized." 88
\end{abstract}

These comments highlight the financial risk for a group of individuals wanting to create a cohousing project in an urban setting. The building sector (including banks, developers and the City) is not geared toward the creation of a one-time project by a group of individuals trying to finance a project. The housing sector relies upon developers, both private and non-for-profit, with a track record of built projects backed by investors who are willing to accept the risks and rewards of investing in real-estate. ${ }^{89}$

The reliability of the organizational structure of a new group is also perceived as an area of risk. The potential for disagreement and conflict amongst multiple clients is real. Traditionally

\footnotetext{
${ }^{87}$ My parentheses

${ }^{88}$ Saide Sayah, Pg.161.

${ }^{89}$ Ibid
} 
builders deal with one owner/investor, and do not have to ride the ups and downs of a group of individuals trying to agree; having unrealistic expectations; or wanting costly changes. Mr. Sayah, goes on to say that the risks do not end with the completion of construction.

In both, the 'not-for-profit' sector and the private sector, Mr. Sayah points out, projects can fail after construction. The management of a multi-residential building requires reliable organization, financial backup, and administration. According to Mr. Sayah, the City of Ottawa sees many projects come close to default as a result of missed mortgage payments and governance difficulties. These risks must be taken into account in a realistic assessment of the long-term viability of the cohousing project. It is one thing to finance the construction of a building, another to finance and administer the long-term maintenance and unexpected repairs. $^{90}$

The Affordable Housing Unit of The City of Ottawa is approached by many communities in the city looking for funding for senior housing options. Often communities come with substantial resources - finances, land and personnel. The one thing they are often missing is experience in operating a multi-unit building.

"Almost every ethnic group has come to us for seniors housing: Lebanese, the Coptic Church, the Greek Orthodox community, the Portuguese, the Chinese; there's so much demand. Some of them come to us with very significant resources; they've come to us with land, with fundraised money - but they don't have any experience operating an apartment building. This is a big red flag to us; I can't stress that enough."

Whether a group uses a private developer, or a not-for-profit provider, Mr. Sayah points to the reality that the builder will walk away after construction, and the (cohousing) organization will be left with the responsibility for operating the building long-term. The same is true of development consultants; they are around for the short-term, not the long-term. Mr. Sayah returned to the crucial role that the operational piece plays in a project's success, stressing that even experienced housing providers run into significant financial difficulties.

\footnotetext{
${ }^{90}$ Sayah, interview. Pg. 161.

${ }^{91}$ Sayah, interview. Pg. 162.
} 
From the City's perspective the viability of a housing provider is an important consideration. Housing providers such as the Centretown Citizens Ottawa Corporation (CCOC) and Ottawa Community Housing Corporation $(\mathrm{OCH})$ have proven their financial sustainability over time and are considered reliable partners by the City. The city is cautious about new housing organizations that consist of a one-building proposal and a board, with no track record. They are more likely to support a new entrant into the housing market if it is partnered with an existing housing corporation that has a track record. The partnership reduces the risk for all parties - the individual members, and the City - if the group can share the economic efficiencies with another organization who has greater financial and operational capacity.

Another cautionary note Mr. Sayah struck, is reflected in the following statement: "With small affordable housing providers, it can be one person that is making it all work; and when that person leaves, we can often see the organization go into a crisis. We are very aware of that here at the City. "92

This statement made me reflect on my experience with Convivium Cohousing for Seniors. During the early IHOA phase, as well as the formative period for Convivium, the majority of the energy and time was provided by one individual; that person's drive and commitment kept the group in a forward momentum. During the transition period from IHOA to Convivium, when potential residents were starting their own group, there was a temporary shift in the energy and character of the group. In Convivium's case, there was another 'burning soul' (Lynne Markell) who took up the reigns, along with a number of other experienced and intelligent members. However, what might happen if a 'leader' resigns, remains an ongoing concern for any group. The City seems aware of this potential for internal crisis.

\footnotetext{
${ }^{92}$ Sayah, interview. Pg. 163.
} 


\subsection{New Construction is Expensive}

Many of the experts interviewed, including Mr. Sayah, emphasized the high cost of new construction. Current construction costs in Ottawa, as well as other major metropolitan areas in Canada, are a significant hurdle for any self-funded project. Given our market-based housing sector, the demand for new housing within city limits has driven the costs of both land and construction to new levels. This means, that even for projects that the City helps subsidize, rents can be high. In a recently funded project of 'cluster units' ${ }^{93}$ the break-even rent for a bachelor suite is $\$ 1800$, and for a two bedroom it is $\$ 2200$ a month. These rents reflect comparable rents for a newly constructed cohousing project.

The cost of land within the city of Ottawa has risen to prohibitive levels - especially for new organizations - adding substantially to the cost of units. Ottawa's geography is unique in that its core is developed within a Green Belt, driving land values even higher within this zone. ${ }^{94}$ The density that developers need to achieve, to reach financial viability on expensive land, means that most inner-city projects must be built as multi-unit high-rises. The desire of a cohousing group to maintain a workable community size dictates that a building be somewhere in the range of 25-35 units. This size constraint makes it difficult for a cohousing project to succeed in a competitive market; without constructing a much larger building, cost efficiencies are likely to be impossible to reach. In addition, the requirement to provide common spaces and amenities will drive the per sq. ft. cost up in comparison to unit costs for other market units that do not have shared space in the building.

\subsection{Creating Senior Cohousing: Potential Development Opportunities}

(with the City of Ottawa)

Having outlined the hurdles exposed by Mr. Sayah, the question regarding how a senior cohousing project might be realized, remains to be addressed. If a cohousing project is looking for support from the City of Ottawa, there appear to be limited possibilities. In Mr. Sayah's

\footnotetext{
${ }^{93}$ Sayah, interview. Pg. 157.

${ }^{94}$ Sayah, interview. Pg. 165.
} 
opinion, leveraging partnerships with existing non-profit organizations could be a way forward. Currently the City works with over 250 local partners and agencies, including retirement home operators, hospitals, the Local Health Integration Unit (LHIU), not-for-profits and faith-based groups. Often the City is unable to offer these organizations financial subsidies but will support them by trying to facilitate partnerships with other funded organizations. ${ }^{95}$

Mr. Sayah described how the City of Ottawa facilitated the Rideau-Perley and Bruyere Continuing Care to leverage their resources:

"With Bruyere, the Sisters of Charity gave them the land; they came to us for development charge relief, and for capital funding; then they got low interest financing from Infrastructure Ontario...they hired the same architect, the same market researchers, same engineers. They had both specialized in senior's care and long-term care, but they hadn't done independent seniors living before. Eventually they broke off and did their own thing, but they really worked closely together."

The City is moving in the direction of supporting mixed-income communities. This structuring allows for some of the units in a building to be subsidized and others to be rented at market rate (billable market runs). The landlord, or co-op can charge market rent for a segment of the units, which could potentially allow for a moderate to middle income group to lease the units. The possibility of leasing a couple of floors in a newly built subsidized project was raised a number of times by Mr. Sayah. The number of subsidized units could be, say for example, 45 out of 200 , with the rest renting on the open market.

Not only are newly-planned buildings moving in the direction of mixed-income, but entire areas are being planned as mixed-neighbourhoods, combining private sector housing, senior residences and affordable home ownership, with a variety of services and residents. The Building Better Revitalized Neighbourhoods program could offer opportunities for a new cohousing project to be supported within such a development.

\footnotetext{
95 "The Perley Rideau and Bruyere Continuing Care groups received 5.5 million dollars of funding from the City of Ottawa that subsidized 45 of 139 units at the Perley Rideau and 45 of 221 units at the Bruyere Continuing Care. The Eastern Ontario Christian Co-op also received funding from the City." Interview with Mr. S. Sayah. Pg. 167.

${ }^{96}$ Sayah, interview. Pg. 164.
} 
"We'll be putting out RFPs (Request for Proposals), so there could be opportunities for new developers to come in; we'd be looking for innovative solutions like cohousing. We're continuing to look at these ideas but what we need is to see a group of residents willing to sign leases, make agreements of purchase and sale on these units. It would have to be in a building that would be acceptable to the residents and to the City. I think for seniors we could probably do that." 97

Although fraught with its own set of challenges, Mr. Sayah raised the possibility of approaching a private developer. In his opinion, a cohousing group could look for a developer who is familiar with building multi-unit housing and is willing to take a chance on a new type of project. Similarly, the cohousing group could approach a non-profit housing provider to explore interest in a collaboration.

In questioning Mr. Sayah regarding potential financial support for home-ownership, as opposed to rental, he responded that the City of Ottawa used to have an Affordable Home Ownership Program. During the 2008 economic crash, the Conservative government agreed to make a number of home ownership down-payment loans available, on a first come, first serve basis; the idea was to give the residential sector a boost. Within a few weeks the federal funds that had been set aside had run out. In the current financial market, the City (with Provincial direction) could take money out of their budget to support a similar program and are considering reintroducing the program. Currently, only Habitat for Humanity is supported in this way.

As a last encouraging note, Mr. Sayah offered the following:

"I would just note one other thing; the province is asking us to look at more $\underline{\mathrm{Hub}}$ concepts - leveraging co-locations. There could be opportunities in the next couple of years to see something like cohousing happen. My view is that it would have to be simple - I mean it could still be a nice design, eloquent, with the

\footnotetext{
${ }^{97}$ Sayah, interview. Pg. 166.
} 
shared spaces; but in terms of ownership and operations, it's going to have to be really straight forward."198

\subsection{Summary: Too Risky for the City}

It would seem that current opportunities of working with the City of Ottawa Housing Services Branch are limited and unlikely. From the City's perspective, the risks inherent in a citizen initiated cohousing project, outweigh the possible gains. The reliability of the organizational structure of the cohousing group, the financial viability and sustainability of its business plan, and the lack of experience in the operational side of a multi-unit residence, are all reasons for the City to lack confidence in a project proposal brought forward by a cohousing group.

It would appear that the best potential for a cohousing project to succeed exists in creating a partnership with an organization, or housing providers that is established and considered reliable by the City. Partnering with an existing housing corporation, with a proven track record, could help leverage existing funds and offer the opportunity to share economic efficiencies with an organization that has greater financial and operational capacity. The City has indicated a willingness to facilitate such partnerships by raising the interests of new groups to its existing base of housing providers.

Mr. Sayah did indicate an openness to innovative housing solutions within mixed-income neighbourhoods. The recent support for the Hub neighbourhood approach also offers some possible ways forward. If a cohousing group is willing to locate on several floors of a mixedincome housing project, or to consider locating its project within a revitalized neighbourhood, they could harness new possibilities of collaboration with the City.

Ultimately, public policy needs to evolve in the direction of including the moderate to middle income resident; only in this way will cohousing be in a position to utilize City resources. The mechanisms by which a senior cohousing project could leverage some of the City's financial and land resources by locating side by side with other City-sponsored housing projects, has yet to be seen.

\footnotetext{
${ }^{98}$ Sayah, interview. Pg. 178.
} 
Part 07

\section{Conclusions:}

\section{What could the future look like?}

The failure of $90 \%$ of start-up cohousing groups in North America to manifest a built cohousing project (as quoted by cohousing consultants) ${ }^{99}$ can be interpreted as exposing deficiencies in our capacity as a Canadian society to support innovative and unconventional housing solutions. The structure of existing institutions and organizations does not, presently, appear to have the flexibility to accommodate a challenge to traditional approaches in financing, governance and housing.

In considering some of the strategies that might help enable cohousing in the future, there are a number of avenues that governments, financial institutions, and local initiatives and the cohousing groups themselves, could pursue. Some of these are presented below.

There has been limited financial analysis of the benefits that senior cohousing can offer to expenditures in the health-care sector (physical and mental health-care) and in minimizing the ecological footprint of our current lifestyles on the planet. Without this kind of research across sectors, the full scope of the benefits that cohousing can offer will not be revealed. Government subsidies, low-interest loans or mortgages through $\mathrm{CMHC}$, and other financial assistance are not currently available to the equity cohousing venture. As a result of the lack of political will and public funding, cohousing projects, at present are only viable as endeavours of 'well-to-do' seniors, or other groups, who have enough money to invest in their own housing.

The lack of professional development support was one of the reasons most often cited during the interviews for the failure of cohousing starts. In response to this need, a program that would fund building industry professionals to train in cohousing development should be

\footnotetext{
${ }^{99}$ Christian. Creating a Life Together. 2003; M. Critchlow Workshop; S. Raymond, Solterra. http://solterraco-housing.com
} 
established to better the chances of success in the context of present legislation and policies, which do not address the broad spectrum of housing interests, and instead focus on social housing for those in need. This would offer aspiring groups the expertise of a trained 'cohousing development consultant ${ }^{\prime 100}$. For example, CMHC, or Cahdco could be asked to cover the costs of training select employees to create project groups for new cohousing groups. Training programs are currently available through Charles Durrett and Katie McCamant in the USA, and Ronaye Matthew in Canada.

In addition, these same organizations could form small groups of trained employees and locate them in the community as resource centres for potential cohousing groups. A team that is experienced and available to share 'best practices' would go a long way to supporting new cohousing ventures. In lieu of forming their own internal groups, CMHC could offer seed funding to cover the costs of establishing a cohousing consultancy.

Another hurdle for cohousing groups (especially in urban areas) is the acquisition of land. Here again, there is room for government programs to enable community organized groups to gain preferential access to government owned lands. The establishment of a City Land Bank by the City of Ottawa could facilitate the sale of surplus land to projects that complement community strategies, including cohousing. ${ }^{101} \mathrm{CMHC}$ could, in-turn, set up a program that would offer bridge financing, or mortgage loans at reduced interest rates for a cohousing group wanting to purchase land.

Banks and credit unions could re-assess the financial viability of non-traditional financing structures (e.g. equity co-operatives) on the merit of the assets of the future residents and the project itself. Currently banks are not likely to give mortgages to unconventional housing tenures, or to groups of community members who, although soluble, are not proven

\footnotetext{
${ }^{100}$ Interviews with D. Kardish, R. Matthew, K. McCamant, G. Hussey.

${ }^{101}$ Center for Community Progress. http://www.communityprogress.net/land-banking-faq-pages-449.php (website accessed April 2018)
} 
developers, or well-known non-profit organizations. ${ }^{102}$ Cohousing groups, for their part, need to learn how to approach financial institutions; in doing so the bank or credit union, may realize that cohousing is actually a less risky investment than conventional development; unlike a conventional development project, the units are already sold to buyers who are invested in the development and the success of the project. ${ }^{103}$

Municipal planning departments could support the building of innovative projects by community groups. Existing zoning regulations on the number of units, or storeys in a project could be relaxed for non-profit community groups. This would permit an 'up-scaling' on certain sites to enable lower unit costs for the entire project, or alternatively, provide for a 'nonmarket component' of units with lower costs (the land cost would not be included in those units). This 'density-bonus', ${ }^{104}$ where the municipality agrees to build to a higher density than would normally be possible for a conventional market development, could be an effective method to support economic diversity. The appetite, or lack thereof, of the local political environment to create non-market housing can determine whether the municipal planning departments is open to developing a vehicle for providing this kind of variance. ${ }^{105}$

Provincial and Municipal 'affordable housing' programs could support the inclusion of subsidized units (to a certain percentage) in cohousing projects and find ways to enable cohousing communities to include low to moderate income members already affiliated with the group. 'Affordable housing' wait-lists specifically for cohousing communities could be established. Exploring housing alternatives with a mix of ownership and rental units also holds some promise. New housing programs that support community-initiated innovative solutions could also be explored and implemented.

As developers become familiar with the process of creating cohousing and discover that cohousing members are trustworthy clients, they may be more willing to work with cohousing

\footnotetext{
102 Interview with K. McCamant. Pg. 189.

103 Interview with R. Matthew. Pg. 200.

${ }^{104}$ Interview with R. Matthew. Pg. 203.

105 Ibid.
} 
groups. This potential, however, also points to the responsibility of the cohousing group to become better organized, and to work with consultants to develop a strong business case to become reliable partners for a developer.

Ultimately, the most powerful way to encourage innovative housing is to enable it at the policy level. The federal, provincial and municipal governments all have the capacity to influence the future direction that housing will take in this country. The National Housing Strategy missed an opportunity to address the housing affordability crisis in Canada by focusing only on those most in need in our society (affordable/social housing). Responding to the changing demographic where seniors will soon make up more than one third of our population is a responsibility that needs to be taken seriously and addressed in a timely manner. The desire of seniors to live a connected and healthy old age is their human right.

To view (senior) housing issues within a holistic context rather than as an autonomous sector, could hold the key to a healthier population and a stronger economy. Our society is facing a 'loneliness epidemic' ${ }^{106}$; an aging population with a higher incidence of dementia; a health care system experiencing a shortage of hospital beds (beds are often occupied by seniors who are awaiting a long-term care placement); a housing affordability crisis, and a growing need to take care of our environment. To view these manifestations in an interconnected way, taking into account the impact of one issue on the other, could offer new perspectives to our current challenges.

\footnotetext{
${ }^{106}$ Yeginsu, Ceylan. “UK Appoints a Minister for Loneliness”. The New York Times. Jan 17, 2018. https://www.nytimes.com/2018/01/17/world/europe/uk-britain-loneliness.html
} 
Epílogue

More Questions than Answers

While an epilogue is intended as an ending or conclusion, this epilogue cannot claim to be either an ending or a statement of finality. Convivium as a project continues to evolve; no land has been secured yet, and the development process continues to feel uncertain. The best-practices for creating a cohousing community are still in their infancy in Eastern canada, and no new cohousing projects are currently being built here. Although K. Mocamant in the US, and R. Matthew in British columbia, both cohousing development consultants, have created templates and best practices for those locations, self-initiated projects continue to struggle in ottawa, Toronto and elsewhere in the eastern provinces.

New questions have joined the numerous questions that provided the impetus for this thesis topic. How can a city support its citizens to create self-initiated projects in a market economy? How can a cohousing group secure land in a tight market where for-profit developers have the upper hand in resources, investors and timing? How can new models of development become viable to financial institutions, developers and city planners? What can government do to support housing affordability? can we as a society define new standards of architecture based on a sharing of public and private resources? Will planning departments adopt these? These questions are crucial to address if we are to create a fair and equal opportunity for all citizens to live in housing that meets their needs and provides a healthy and livable environment for all citizens of the city.

1 recently stumbled upon two articles that helped to shed light on some of the questions I still ponder and point to possible ways forward. Jennifer Keesmaat, former chief Planner of the city of Toronto, in conversation with Robyn Bresnahan on CBC Morning, 107 out to the heart of the many housing issues that face our cities; and Kristien Ring, Berlin architect and writer of the Self-Made city: Strategies for Future urban Living, spoke directly to the power of the 'baugruppe' movement in Berlin, and the potential of self-initiated citizen projects.108

Most of canada's population lives in dense urban environments, creating new imperatives for ecological stewardship and for providing affordable housing for families, the aged and those working in the city. Citizens should not need to move out of the city to the suburbs or rural areas to meet our housing needs. How can we begin to transform our cities to address these needs?

\footnotetext{
${ }^{107}$ Interview with Jennifer Keesmaat, "A New Solution for the Affordable Housing Crunch". Conducted by Robyn Bresnahan. Ottawa Morning, CBC. May 17, 2018.

${ }^{108}$ Keynote address by Kristien Ring, "Self-Made City: Strategies for Future Urban Living". Design and the City Conference, Amsterdam University of Applied Sciences. April 19-22, 2016.
} 
Kristien Ring speaks to how in Berlin citizens are actively transforming the city in self-initiated projects, called 'baugruppe', or 'building groups'. Ownership-based forms of cohousing and rental coops are providing affordable housing for city dwellers and creating revitalized neighborhoods. "In the Last 10 years, hundreds of projects have been developed by residents through an ownership-based form of co-housing called the baugruppe. Furthermore, new co-op associations are increasingly building rental, community-determined and socially oriented urban projects throughout Europe. "rog in partnership with architects and city planners, innovative solutions to contemporary concerns are redefining ways to live and work in the city, as well as creating new standards in architecture for what constitutes 'good' housing. New guidelines for city competitions that include requirements for contributing to the neighborhood economy and community living are being adopted.

Most often our cities are determined by profit-driven developments and investments that are oriented to the short-term. 110 The idea that the citizens of a city can redefine how they live is revolutionary. In canada and the us there are few precedents for housing projects that have been determined by future 'users' or residents of a project. All self-managed projects empower residents to make decisions for themselves, rather than 'buy into' for-profit developer models, the market economy, or government programs. It is the 'users' who decide what to spend their money on, what to invest in or save on, what their priorities are: it is not the market that dictates their options. "This creates a new relationship between what you can get for your money; you are making all your own decisions. m11 Self-made housing provides solutions to housing needs that cannot be found in the regular housing market. In Berlin, the 'baugruppe' projects have begun to create savings of $20 \%$ over market-rate housing.

The foundational principle of cohousing also underlies the 'baugruppe' movement: that initiating, managing and creating a building project as a group of citizens can achieve a sustainable, cooperative, living environment that surpasses the options available on the market. The preliminary question for all groups is: "What can we do together as a group that we can't do alone?"12 What can we share? Many cohousing and 'baugruppe' projects find innovative ways to share space that is considered private within conventional market condos. Roof decks, common kitchen and dining, guest apartments, workshops with shared tools, shared gardens and green space all contribute to a new understanding of collaborative living. Fences, private terraces, individual laundry facilities are being re-thought.

\footnotetext{
${ }^{109}$ K. Ring, keynote address.

${ }^{110}$ Ibid

${ }^{111} \mathrm{Ibid}$

${ }^{112}$ Ibid
} 
As a group, efficiencies can be built into the

design and construction process so as to redefine what can be built for what price. But, most importantly sharing space strengthens community bonds and creates a sense of shared responsibility within the community. Within the design phase, there are innovative ways of approaching the transitions inherent to changing family dynamics. Flexible spaces, multi-generational planning and adaptation to special needs are all addressed.

The challenges outlined by MS. Ring and MS. Keesmaat, underscore those already identified in this thesis: issues of securing land and financing, of the time required in organization, finding reliable development partwers and working with the municipality and other policy planners. MS. Ring expands our understanding of the challenge of competing with developers for land. She points to the time that it takes for a group to reach agreement and secure financing for the land and how that places them at a distinct disadvantage when it comes to making a quick decision on a property. The private investor simply has to go to a bank, secure a loan and put in a bid. The larger the site, the more people and the longer the discussion around agreement takes. By now the investor has already bought the land!113

She also points to how the citizen-user has an entirely different set of decision-making criteria to the developer/investor. The developer is looking at decisions from a profitability lens, whereas the resident is looking at decisions from a longer-term perspective; what they will really need for the next 20-30 years. The citizen-user is more invested in the long-term outcome of their living environment, both private and shared.

City planning departments are used to dealing with for-profit developers and Ring suggests that the city needs to adopt innovative mechanisms to include citizen groups in competitions for land and funding. The 'user' as initiator and investor in their own housing is a new paradigm for planning departments. MS. Ring suggests a simple solution: that the city planning department builds a userbased program, not a program oriented to the private owner/developer in which the city establishes a short list of criteria outlining what the best development practices would be from the point of view of contribution to the surrounding neighborhood and its residents. If it is land in question, then the price of the land would be set, and an RFP would bring in contenders. In this way the user-based projects would have a fair chance at a 'best concept' in competitions for land and project funding, and banks would be assured that they are supporting a viable project.114

\footnotetext{
${ }^{113}$ K. Ring, keynote address.

${ }^{114} \mathrm{~K}$. Ring, keynote address.
} 
closer to home, jennifer Keesmaat of Toronto, is laying the groundwork for a future that will include more affordable options for canadians. Having left her job as chief Planner for the city of Toronto six months ago, she has now joined an innovative organization called creating Housing society that is dedicated to building more affordable housing in canada. As CEO of this private/public partnership she promises to position the independent, non-profit provider (and one hopes citizen-groups) to create housing affordability in our cities. In so doing she is addressing one of the most serious issues, of which cohousing participates, that of providing housing for the middleworking class and those on fixed incomes.

Most often, as we have seen, the biggest challenge for groups is buying a site. Whereas, the baugruppe' in Berlin, were able to utilize empty tracks of urban land after the fall of the Berlin wall some of it through long-term leases, Keesmaat is recommending a novel approach to the issue of land acquisition within urban centers. The question, what can government do to support housing affordability, has been answered in a simple, yet sophisticated solution: the use of public land that exists in the public trust needs to be used for the public good.115 one-storey buildings that exist in the dense urban environment: outdated transit stations, libraries, and old community centers, will be redeveloped into new affordable housing close to transit and amenities. MS. Ring in speaking of the baugruppe' in Berlin also stressed the idea that publicly owned land must be used wisely and with long-term social and financial goals in mind.116

In canada we find ourselves in a situation where housing has been commodified and viewed as an asset and as a way to generate wealth. MS. Keesmaat believes that we need to re-orient our thinking as a country to view housing not primarily as a way to generate wealth, but as a way that people can participate in community. We need to rethink what quality housing is and recognize that providing housing affordability is a critical part of what our cities need to provide sustainability for the future.117

Keesmaat insists that government is well aware of the problem, and more than willing to do its part, but needs partners to be able to deliver on its end. Keesmaat is well positioned, as past chief Planner, to understand the housing system and policy planning and has managed to acquire the backing of financial institutions and all levels of government through a partnership with the creative Housing Society. According to Keesmaat, the cities of Toronto and vancouver have already announced policies that indicate surplus lands and key properties will be made available to affordable housing projects; transit stations have already been ear marked for redevelopment into housing projects. Further, she

\footnotetext{
115 J. Keesmaat interviewed.

${ }^{116} \mathrm{~K}$ Ring, keynote address.

117 J. Keesmaat interviewed.
} 
points to a statement in the recent National

federal lands to deliver housing. 118
Housing Strategy that recommends the use of

Keesmaat reiterates what former CMHC program manager, Jamey Burr, underscored in his interview for this thesis: that housing prices rose sharply, and continue to do so, after all funding for affordable housing rental programs disappeared in 1993. Since the federal government's withdrawal from the funding and facilitation of co-ops at that time, the country has seen 30 years without the construction publicly funded affordable rental.

Keesmaat, makes a defining statement when she highlights that, "by definition, providing affordable housing is not a part of the housing market economy." The market has never, and will not, provide affordable housing because there simply is not enough profit in it for investors. 119 This statement holds the key to many of the challenges for the cohousing project. cohousing is not, and has never been, a part of the market economy.

Developers have shown an aversion to working with a client group that is also the user group. This dilemma has resulted in a limited number of development options for cohousing groups and underscores the importance of finding ways to approach and negotiate with potential developers. Many of the experts interviewed for this thesis, emphasized the importance of having a 'client representative', someone who will represent the interests of the cohousing group while understanding the needs of the developer. This could be a cohousing development consultant, an architect, or other professional consultant, but the importance of the group not overwhelming the developer with members all expressing their desires and needs is of paramount importance to the success of the negotiations. in order to support cohousing and other self-initiated projects, alternative types of development need to be seriously considered as a strategy in the architectural profession and on a political level. 120

The other crucial piece to the puzzle of how to create a successful cohousing project lies in the financial arrangements. Currently there is little incentive for investors to put their money behind a model of affordable housing or a cohousing project. The financial viability of such models have yet to be proven to investors. Keesmaat acknowledges, that for the present, these projects will need to rely on government collaboration and incentives to make them viable. To support new construction of affordable rentals, CMHC has recently announced a new construction financing program called the Rental construction Loan Financing Program. Under this program groups will receive construction financing at very low interest rates. If this program were to be

\footnotetext{
118 J. Keesmaat interviewed.

119 lbid.

${ }^{120}$ K. Ring keynote address.
} 
extended to self-initiated citizen projects, such as cohousing, their chances of success would increase greatly. With time and familiarity with the model, it would likely become self-sustaining.

The last point to be made here, is regarding the shift that is needed in our conception of urban housing and the responsibilities of the building industry. It is not enough to build housing that provides shelter for the poorest; housing must reflect our human need for connection and collaboration and add richness to the fabric of our neighborhoods and city. Co-housing and Berlin's version of cohousing, the 'baugruppe', point the way to a future of housing that is integrated, creates community and gives back to the city; affordable and responsible housing that contributes to the health, livelihood and economic development of our cities. Let us become advocates for our own housing and the life of our cities. 


\section{BIBLIOGRAPHY}

Interviews conducted by Author of Thesis (as primary source research material):

Burr, Jamey (Past Program Manager at CMHC; current, Upper Marlowe Consultants). Interview conducted on Oct. 31, 2017. Length: 2:08:50. Location: Upper Marlowe Consultants Office.

Burrows, Carol (Community Advocate; Chair of Affordable Supportive Housing for Seniors Strategic Implementation Task Force, United Way and Centraide Ottawa). Interview conducted on Oct. 16, 2017. Length: 1:20. (transcript not included in thesis document).

Critchlow, Margaret (Co-founder and Director of Canadian Senior Cohousing Society; Professor Emerita York University; associate with Cohousing Development Consulting (CDC)) Interview conducted on Nov. 8, 2017. Length: 1:45:33. Location: Private Office. (transcript not included in thesis document)

Hussey, Graeme (Development Manager for Centretown Citizens Ottawa Corp (CCOC); President of Centertown Affordable Housing Development Corporation (CAHDCO)) Interview conducted on Oct. 27, 2017. Length: 1:12:01. Location: Cahdco Offices.

Johnson, John (Lawyer; Past President of Board of Directors of Council on Aging of Ottawa) Interview conducted on Oct. 20, 2017. Length: 1:20. Location: Private Office. (transcript not included in thesis document)

Kardish, David (Vice-President, Land Development, The Regional Group (Developers); Principal of Greystone Development). Interview conducted on Nov. 21, 2017. Length: 1:09:55. Location: The Regional Group Office.

Matthew, Ronaye (Founder and Principal of Cohousing Development Consulting (CDC); founding member of the Canadian Cohousing Network; member of Cranberry Commons cohousing). Interview conducted on Oct. 24, 2017. length 1:13:10. Interview conducted via Skype.

McCamant, Kathryn. (Architect; Founder and President of CoHousing Solutions (cohousing development consulting services; Co-author of Creating Cohousing: Building Sustainable Communities). Interview conducted on Nov. 6, 2017. Length: 1:01:22. Interview conducted via Skype.

Sayah,Saide (Program Manager Affordable Housing Unit, Housing Services Branch, Community and Social Services Department, City of Ottawa). Interview conducted on Nov. 15, 2017. Length: 2:01:08. Location: Affordable Housing Unit Offices. 


\section{$\underline{B o o k s}$}

Cole, Leslie. 2008. Under Construction: A History of Co-Operative Housing in Canada. Borealis Press.

Christian, Diana Leafe. 2009. Creating a Life Together: Practical Tools to Grow Ecovillages and Intentional Communities. $2^{\text {nd }}$ edition ( $1^{\text {st }}$ edition 2003). Gabriola Island, BC. New Society Publishers.

Durrett, Charles. 2009. The Senior Cohousing Handbook: A Community Approach to Independent Living. Gabriola Island, British Columbia. New Society Publishers.

Durrett, C.; McCamant, Kathryn. 2011. Creating Cohousing: Building Sustainable Communities. Gabriola Island, British Columbia. New Society Publishers.

Eastman, Perkins. 2013. Building Type Basics for Senior Living. Volume 7. 2 nd edition, $\left(1^{\text {st }}\right.$ edition 2004). Wiley and Sons. ISBN:978-1-118-00745-7

Goemans, Magdalene. 2018. "Fostering a 'Community of Care': Supporting a Shared Experience of Aging in Cohousing" in Aging in an Aging Society: Critical Reflections edited by Monique Lanois and Iva Apostolova. Sheffield,UK: Equinox Publishing.

Ring, Kristien. 2013. Self-Made City. Berlin, Self-initiated Urban Living and Architectural Interventions. (Jovis Publishers).

Scott-Hanson, Chris \& Kelly. 2005 revised edition. The Cohousing Handbook: Building a Place for Community. Gabriola Island, BC. New Society Publishers. http://library.uniteddiversity.coop/Ecovillages and Low Impact Development/Cohousing /The Cohousing Handbook-Building a Place for Community.pdf

\section{Journal Articles}

Arbell, Yael. 2016. "A Review of 'The Re-Emergence of Cohousing in Europe', Edited by Lidewij Tummers." International Journal of Housing Policy 16 (4). Routledge: 561-64. doi:10.1080/14616718.2016.1228247.

Arp, Mia. 2016. "Zones of Belonging Experiences from a Danish Study on Belonging, Local Community and Mobility". Geoforum Perspektiv 29: 1-28.

Brenton, Maria. 1999. "Co-operative Living Arrangements among Older Women." Local Environment 4 (1). Taylor \& Francis Group: 79-87. doi:10.1080/13549839908725584. 
De Graaf, Reinier. 2015. "'Architecture Is Now a Tool of Capital, Complicit in a Purpose Antithetical to Its Social Mission."' The Architectural Review.

Holt-Lunstad, Julianne, Timothy B Smith, and J Bradley Layton. 2010. "Social Relationships and Mortality Risk: A Meta-Analytic Review." Edited by Carol Brayne. PLoS Medicine 7 (7). San Francisco, USA: Public Library of Science: e1000316. doi:10.1371/journal.pmed.1000316.

Hughes, David, and Stephen Judd. 2012. Design for Aging: International Case Studies of Building and Program. John Wiley \& Sons.

http://books.google.com/books?hl=en\&lr=\&id=HyeflJfa8ogC\&pgis=1.

Jolanki, Outi, and Anni Vilkko. 2015. "The Meaning of a 'Sense of Community' in a Finnish Senior Co-Housing Community." Journal of Housing for the Elderly 29 (1-2). Routledge: 111-25. doi:10.1080/02763893.2015.989767.

Jones, Emma Letizia. 2016. "How Housing Co-Operatives Built a City (Zurich)." The Architectural Review, no. No. 1435, October 4. https://www.architectural-review.com/how-housing-cooperatives-built-a-city/10012449.article

McFadden, Erica S., and Joanna Lucio. 2014. "Aging in (Privatized) Places: Subsidized Housing Policy and Seniors." Journal of Housing for the Elderly. doi:10.1080/02763893.2014.930364.

Metcalf, Bill. 2012. "Utopian Struggle: Preconceptions and Realities of Intentional Communities." Realizing Utopia, no. 8: 21-28.

Pedersen, Max. 2015. "Senior Co-Housing Communities in Denmark", Journal of Housing for the Elderly, 29:1-2, Pg. 126-145, https://doi.org/10.1080/02763893.2015.989770

Scanlon, Kath, and Melissa Fernández Arrigoitia. 2015. "Development of New Cohousing: Lessons from a London Scheme for the over-50s." Urban Research \& Practice 8 (1). Routledge: 10621. doi:10.1080/17535069.2015.1011430.

Thokle Martens, Christine. 2017. Aging in Which Place? Connecting Aging in Place with Individual Responsibility, Housing Markets, and the Welfare State. Journal of Housing for the Elderly. Vol. 32. doi:10.1080/02763893.2017.1393483.

Tummers, Lidewij. 2015. "Introduction to the Special Issue: Towards a Long-Term Perspective of Self-Managed Collaborative Housing Initiatives." Urban Research \& Practice 8 (1). Routledge: 1-4. doi:10.1080/17535069.2015.1011421. 
Westwood, Sue. "'My Friends are my Family': $\quad$ An argument about the limitations of contemporary law's recognition of relationships in later life". Journal of Social Welfare and Family Law. 2013. 35(3).

Westwood, Sue, and Mary Daly. 2016. "Social Care and Older People in Home and Community Contexts: A Review of Existing Research and Evidence." Department of Social Policy and Intervention and Green Templeton College, University of Oxford.

\section{Conferences and Presentations}

"Building Hospitable Communities for Aging: Challenges and Opportunities". Sept. 28-30, 2016. Keynote speaker: Dr. Elizabeth MacKinlay. University of St. Paul, Ottawa. www.ustpaul.ca/aging

Carriere, Celine. "Co-operatives in Eastern Ontario". Presented to Convivium Cohousing, Executive Director of CHASEO (Co-op Housing Association of Eastern Ontario). 2017

"CMHC Housing Finance Symposium". Conference sponsored by CMHC. Shaw Conference Center. Oct. 10-11, 2017.

Critchlow, Margaret. (Cohousing Development Consulting (CDC) associate). "Aging Well in Community \& Is Cohousing for You?". Workshop presented to Convivium Cohousing. April 28-29, 2017.

Critchlow, Margaret. "Facilitation and Consensus Building". Workshop presented to Convivium Cohousing. Nov. 23-24, 2017.

Hussey, Graeme. "Social Purpose Real Estate Development". Presentation to Convivium Cohousing. Jan. 24, 2018.

Lagace, Martine: Keynote speaker. "Ageism”. Presented at the Council on Aging Annual Spring Luncheon. Shaw Conference Center. April 2017

Leaning, Anthony. "The Passive House". 2017. Presented to Convivium Cohousing for Seniors.

Passive House Tour. Spring 2016. University of Saint-Paul, Ottawa.

Second Co-op Walk: St. George Co-op, Sandy Hill Co-op, Conservation Co-op, Co-op Voisin. (Jane's Walk Ottawa). May 6,2017. Presented by the Ottawa Co-operative Network. www.janeswalkottawa.ca

Torge, Janet. "Radical Resthomes". Nov. 7, 2017. Presented at St. Paul University, Ottawa 


\section{Radio Documentaries}

Baba Yaga's House. May, 2013. Radio. Written and Directed by David Gutnick. The Sunday Edition, CBC Radio. http://www.cbc.ca/radio/thesundayedition/baba-yaga-s-housedocumentary-1.1728253 (accessed May, 2017)

Baba Yaga House, The Sequel. Aug. 2013. The Sunday Edition with Michael Enright. Documentary produced by David Gutnick. CBC Radio.

http://www.cbc.ca/radio/thesundayedition/baba-yaga-house-the-sequel-1.2904740

Being Mortal. Feb. 10, 2015. Television. Directed by Thomas Jennings. Written by Atul Gawande and Thomas Jennings. PBS Frontline. Season 33, 6.

Home Truths (series). The Sunday Edition with Michael Enright. CBC Radio.

Part 1. Why Canada needs a New National Housing Policy - Now! (May 28, 2017)

Part 2. What's Causing Canada's Housing Crisis? (Sept. 17, 2017)

Part 3. Innovative Solutions for Affordable Housing. (Oct. 1, 2017)

Part 4. Imaginative Solutions for an Overheated Housing Market. (Dec 8, 2017)

http://www.cbc.ca/amp/1.4313111

http://www.cbc.ca/listen/shows/sunday-edition/segment/14202204

Radical Resthomes. Jan. 2015. Living Arrangements Part 2: Radical Resthomes. (Janet Torge speaks to a group in Ottawa) Nov. 2, 2014. The Sunday Edition with Micheal Enright. CBC Radio. http://www.cbc.ca/radio/thesundayedition/the-ghomeshi-effect-dick-cavett-livingarrangements-pt-1-couch-living-ebola-and-global-public-health-living-arrangements-pt-2radical-resthomes-1.2905271/radical-resthomes-1.2905280

\section{Online Media}

Elliot, Erica. Cohousing: Community at its Best. TEDx ABQ. 9:57. Posted by TEDx Talks. Oct. 16, 2015. http://www.cohousing.org/node/3939

Kim, Grace. How Cohousing can make us happier (and live longer). TED 2017. 10:15. Posted by TED Conference Talks. April 2017.

https://www.ted.com/talks/grace_kim_how_cohousing_can_make_us_happier_and_live_I onger\#t-2098

Kitchen, Roger. What Makes a Community? TEDxMiltonKeyes. 15:41. Posted by TEDx Talks. Oct 15, 2012. https://www.youtube.com/watch?v=bjVq_Dlrflk

Ring, Kristien. SELFMADE CITY Berlin: Self-Initiated Urban Living and Architectural Interventions in Berlin (keynote lecture by co-housing specialist and architect K. Ring from Berlin).You Tube 
video. 30:21. Design in the City

Conference, Amsterdam, Amsterdam

University of Applied Sciences. April 2016. http://aa-projects.eu/tag/baugruppen-and-co-

housing-in-berlin/

https://designandthecity.eu/it-is-not-about-expanding-our-cities-but-making-them-better/

Taylor, Barbara. "Are we more lonely than our ancestors?". BBC Radio 3. Free Thinking Festival 2018: The One and the Many.

http://www.bbc.co.uk/programmes/articles/2hGYMPLFwx5IQyRPzhTHR9f/are-we-more-

lonely-than-our-

ancestors?intc type=singletheme\&intc location=radio3\&intc campaign=freethinking\&intc linkname=article lonely contentcard3

Soligard, Rikke. How to Create Happy Communities. TEDxArendal. 6:19. Posted by TEDx Talks.

Oct. 2014. https://www.youtube.com/watch?v=KN9T S3IvJU

\section{Newspaper Articles Online}

Barrett, Jessica. "Support for shared housing vital to Vancouver's future".

Vancouver Courier. April 18, 2016. http://www.vancourier.com/opinion/support-for-sharedhousing-vital-to-vancouver-s-future-1.2233620

CMHC Report. "Availability of rental housing in GTA falls to 16-year low, CMHC says"

New report says average vacancy rate across all forms of rental housing fell to 1.1 per cent. CBC News · Posted: Nov 28, 2017. http://www.cbc.ca/news/canada/toronto/cmhc-rentalhousing-gta-report-2017-1.4422672

Chung, Emily. "How Canadians are constructing North America's biggest green buildings". University of Toronto residence and Vancouver high-rises will take passive house design to new scale. CBC News. Posted: Dec 11, 2017. http://www.cbc.ca/news/technology/passivehouse-highrises-1.4437973

CMHC Report. "Average rent for 2-bedroom apartment in Canada hits \$989, up 2.7\% in past year". CBC News. Posted: Nov 28, 2017. http://www.cbc.ca/news/business/cmhcapartment-renting-1.4422568

Curry, Bill (Parliamentary Reporter, Ottawa). National Housing Strategy: "Ottawa to offer direct subsidies to low-income tenants". Globe and Mail, Nov.22, 2017. https://www.theglobeandmail.com/news/politics/expanded-national-housing-strategy-toinclude-new-rent-subsidies/article37046894/

Curry, Bill (Parliamentary Reporter, Ottawa). National Housing Strategy: "Home Ownership is Key to New Housing Strategy, report urges". Globe and Mail, Nov. 15, 2017. 
https://www.theglobeandmail.com/news/politics/national-housing-strategy-should-focus-onboosting-home-ownership-report/article36985761

Easton, Mark. "How should we tackle the loneliness epidemic?" BBC News. Posted: Feb. 11, 2018. https://www.bbc.com/news/amp/uk-42887932

Fatah, Natasha. "New minister of loneliness to tackle solitude in U.K." CBC News. Published on Jan 17, 2018 https://youtu.be/udRNgM4x2W4

Hansen, Jacqueline. "Ultra-low rental vacancy rates highlight 'desperate' struggle to find affordable housing". CBC News · Posted: Nov 29, 2017. http://www.cbc.ca/news/business/no-vacancy-rental-struggles-1.4423963

'Intergenerational' retirement home sees students live alongside the elderly" (Humanitas retirement home in Deventer, Netherlands). CTV News. Dec. 7, 2014 https://www.ctvnews.ca/health/intergenerational-retirement-home-sees-students-livealongside-the-elderly-1.2136659

Kluger, Jeffrey. "'Everyone Needs Someone Else': Why Americans of All Ages Are Embracing Communal Living". Time.com http://time.com/intentional-communities/?xid=emailshare

O'Connor, Naoibh. "Prospective home owners adopt 'cohousing lite' model"

Vancouver Courier. Posted Nov. 29, 2016. http://www.vancourier.com/news/prospective-homeowners-adopt-cohousing-lite-model-1.3402109

O'Connor, Naoibh. "Resident dishes on life in Vancouver's first cohousing development"; Two years in: Consensus building, shared space and four group meals a week Vancouver Courier. Posted Jan. 19, 2018. http://www.vancourier.com/community/residentdishes-on-life-in-vancouver-s-first-cohousing-development-1.23149536

O'Connor, Naoibh. "Things looking up for city's second co-housing complex"; Six-storey Riley Park development to include shared common areas, meals, duties Vancouver Courier. Nov. 22, 2016. http://www.vancourier.com/news/things-looking-up-for-citys-second-co-housing-complex-1.3076547

O'Connor, Naoibh. "Lonely? Maybe cohousing is one of the cures";

Cohousing conference takes place this weekend in Vancouver

Vancouver Courier. April 27,2018. http://www.vancourier.com/real-estate/lonely-maybecohousing-is-one-of-the-cures-1.23284118 
Powers, Lucas. "Ontario Liberals bet big on seniors' care, drug and dental coverage in 2018 pre-election budget"; Pledges $\$ 20.3$ billion in new spending over 3 years, and deficits too. CBC News. Posted: Mar 28, 2018. http://www.cbc.ca/news/canada/toronto/ontarioliberals-budget-2018-1.4595213

PwC and the Urban Land Institute: Emerging Trends in Real Estate ${ }^{\circledR} 2017$. Washington, D.C.: PwC and the Urban Land Institute, 2016. http://read.ca.pwc.com/i/741231-emerging-trends-inreal-estate-2017/8

Speer, Sean. "Federal Housing Strategy ignores market-based issues". Special to Postmedia Network. Nov. 24, 2017

Tindal, Doug. "Toronto Cohousing Communities". Wine on the Porch Website. April 25, 2016. https://wineontheporch.wordpress.com/2016/04/25/toronto-co-housing-communities/ (accessed Feb. 25, 2018)

Yeginsu, Ceylan. "UK Appoints a Minister for Loneliness". The New York Times. Jan 17, 2018. https://www.nytimes.com/2018/01/17/world/europe/uk-britain-loneliness.html

Zimonjic, Peter. "Liberals detail \$40B for 10-year national housing strategy, introduce Canada Housing Benefit"; New strategy aims to build 100,000 new units, repair 300,000 and cut homelessness by 50\%. CBC News. Posted: Nov 22, 2017. http://www.cbc.ca/news/politics/housing-national-benefit-1.4413615

Logan, D. "Common reasons an Ecovillage fails to get off the ground." Permies: Homesteading and Permaculture. Blog Post. Posted Nov. 2, 2014.

https://permies.com/mobile/t/40907/Common-reasons-Ecovillage-fails-ground

\section{$\underline{\text { Websites }}$}

Canadian Cohousing Network. http://www.cohousing.ca/ (accessed Sept. 2017)

Canadian Senior Cohousing. http://canadianseniorcohousing.com/

Canada Lands Company (regarding Booth St. Lands). http://www.rueboothstreet.ca/home www.clc.ca

Center for Community Progress. http://www.communityprogress.net/land-banking-faq-pages449.php (website accessed April 2018)

Cohousing Association of the United States (CoHo). http://www.cohousing.org/ (accessed Sept. 2017) 
Cohousing Development Consulting. Ronaye Matthew principal.

http://www.cohousingconsulting.ca/

Cohousing Solutions. Kathryn McCamant president. http://cohousing-solutions.com/

Communitas. Lynn Hannley principal. www.communitas.ca

LiveWell Cohousing: Building sustainable communities together. http://livewellcohousing.ca/

NHS Alliance (England). http://www.nhsalliance.org/wp-content/uploads/2014/10/THINK-

BIGACT-NOW-FINAL-1.pdf

Solterra Project. Raymond, Shelley principal. http://solterraco-housing.com

The Tyee. Paulsen, Monte. 1997. "A Home for All: In Search of Solutions to Affordability." A Tyee Series on Affordable Housing. https://thetyee.ca/Topic/Housing/

Urban Cohousing Associates. Chris Scott-Hansen, Principal.

http://www.urbancohousingassociates.com/resources/affordable-cohousing/

\section{Government Websites}

City of Ottawa. 10 Year Housing and Homelessness Plan. Sept. 25, 2013

https://ottawa.ca/en/residents/social-services/housing\#our-10-year-housing-

homelessness-plan

City of Ottawa. Action Ottawa: Affordable Housing Initiative, Program Guidelines 2003

http://ottawa.ca/calendar/ottawa/citycouncil/hrssc/2003/09-04/ACS2003-PEO-HOU-

0004\%20Attachment\%201.htm

https://ottawa.ca/en/residents/social-services/housing/affordable-housing

Ontario Renovates Program, City of Ottawa. https://ottawa.ca/en/residents/social-

services/housing/ontario-renovates-program

Statistics Canada. 2016 Census. Government of Canada. 2016.

http://www12.statcan.gc.ca/census-recensement/index-eng.cfm

\section{Government Reports:}

Canada's National Housing Strategy: A Place to Call Home. Government of Canada. Nov. 22, 2017. https://www.placetocallhome.ca/pdfs/Canada-National-Housing-Strategy.pdf 
Housing for Older Canadians: The Definitive Guide to the Over-55 Market: Vol. 3, Planning the Project: CMHC Publications and Reports. 2012. \# 67662 https://www03.cmhcschl.gc.ca/catalog/productDetail.cfm?lang=en\&cat=178\&itm=185\&fr=1518811898151

Housing for Older Canadians: The Definitive Guide to the Over-55 Market: Vol. 2, Responding to the Market. CMHC Publications and Reports. 2012. doi:NH15-295/1-2012E.

"Municipal Tools for Affordable Housing". 2011. Provincial Planning Policy Branch, Ministry of Municipal Affairs and Housing. Province of Ontario.

"Ontario's Long-Term Affordable Housing Strategy update". March 2016. Province of Ontario. www.ontario.ca/housingstrategy

"Policy Statement: Service Manager Housing and Homelessness Plans". Updated 2016. Province of Ontario. www.ontario.ca/housing

Rea W, Yuen J, Engeland J, Figueroa R. "The dynamics of housing affordability. Perspectives on Labour and Income" (Statistics Canada, Catalogue 75-001) January, 2008; 9(1):15-26. "Those living alone, and female lone parent families are the most likely to spend above the benchmark: $42 \%$ and $44 \%$ respectively in 2004 , more than double the proportion in the population as a whole (20\%)."

"Thinking about Aging in Place." Federal/Provincial/Territorial Ministers Responsible for Seniors. 2014. Human Resources and Skills Development Canada.

https://www.canada.ca/content/dam/esdcedsc/documents/corporate/seniors/forum/paip-cl.pdf

"What We Heard: Shaping Canada's National Housing Strategy". Government of Canada. 2016. 1-66. The Conference Board of Canada. https://www.letstalkhousing.ca/pdfs/what-weheard.pdf. https://www.placetocallhome.ca/

\section{Association Reports}

Bacchus Barua, Milagros Palacios, and Joel Emes (2017). The Sustainability of Health Care Spending in Canada 2017. Fraser Institute. <http://www. fraserinstitute.org> and Canadian Institute for Health Information [CIHI] (2016). National Health Expenditure Trends, 1975 to 2016. Canadian Institute for Health Information. doi:10.1017/CBO9781107415324.004

Blegg, Jane Ellen (Team Coordinator). 2016. "Flower City Cohousing Community Affordability Report". 
Bressen, Tree. 2012. "Consensus Decision-

Making: What, Why, How?"

Bressen, Tree. 2016 "The Top 10 Most Common Mistakes in Consensus Process and What to Do Instead."

Brooks-Cleator, Lauren \& Munroe, Joy. Aug. 2016. Seniors Housing Report Ontario. The Council on Aging of Ottawa.

Burr, Jamie. History of Affordable Housing in Ontario. Unpublished material shared with the author of this thesis.

Cahdco. Schedule A: Project Management Services Agreement with Convivium Cohousing. Pg. 1\&2. 2018.

“Canopy Cohousing Membership Manual." 2016. Toronto. http://canopycohousing.ca/wpcontent/uploads/2010/04/CANOPY-Membership-Manual- March-2016.pdf

Carr, Dennis (Consultant with Cahdco). "Pre-Construction Cash-Flow Analysis". 2017.

Entin, David; Kim, Grace; McCamant, Katie. "Affordable Cohousing Toolkit: A Summary of Public and Private Affordable Housing Programs" by Affordable Cohousing Task Group. The Cohousing Association of the U.S., June 2010.

http://www.cohousing.org/sites/default/files/attachments/affordable summary.pdf

Fourth Industrial Revolution for the Earth; Harnessing the 4th Industrial Revolution for Sustainable Emerging Cities. PWC UK in collaboration with the World Economic Forum. https://www.pwc.com/gx/en/services/sustainability/publications/sustainable-emergingcities.html

Nasman, N.; Dowling, D.; Combes, B.; Herweijer, C. November 2017

Scott-Hansen, Chris. "Creating More Affordability in Your Community: A Selection of Ideas," Urban Cohousing Associates, Inc., 2015, www.urbancohousingassociates.com. www.cohousing.org/node/2977 (accessed March, 2018)

Skelton, Ian. Oct. 2002. "Supporting Identity and Social Needs: the too many faces of coop housing". Department of City Planning, University of Manitoba.

Speer and Londerville. "A Home to Call Our Own: A Federal Strategy for Affordable and Responsible Homeownership". A Macdonald-Laurier Institute Publication, Nov. 2017. https://macdonaldlaurier.ca/files/pdf/MLI FederalHousing webF.pdf 
"Think Big, Act Now: Creating a Community of Care". National Health Service Alliance (UK) 2014. https://www.nhsalliance.org/wp-content/uploads/2014/10/THINK-BIGACT-NOWFINAL-1.pdf 


\section{Appendix A}

\section{List of Sector Experts Interviewed for Thesis}

\section{Organizational Contacts}

1. Graeme Hussey (Interview conducted on Oct. 27, 2017) length 1:12:01

Development Manager for Centretown Citizens Ottawa Corp (CCOC)

President of Centertown Affordable Housing Development Corporation (CAHDCO)

101 Catherine St. CCOC Beaver Barracks, Ottawa

Graeme Hussey is the development manager for CCOC and president of Cahdco. He is the cocreator of Broadening the Base, a collaboration to create land and finance mechanisms to develop affordable rental housing and is currently a member of the Housing Services Corporation Regeneration and Asset Sustainability committee and the board of the Ottawa Alliance to End Homelessness. Graeme's educational background is in environmental engineering and project management, and he has 15 years of experience developing and managing social enterprises in the affordable housing, social investment, and food security sectors. Graeme's leadership has been recognized by the Maytree Foundation, Ontario Co-operative Association and Toronto Food Policy Council.

2. Jamey Burr (Interview conducted on Oct. 31, 2017) length 2:08:50 Upper Marlowe Consultants Past Program Manager at CMHC

Consultant hired by Convivium

Jamey Burr administered government housing programs for $\mathrm{CMHC}$. When the programs were cancelled in 1992, my work evolved to trying to find new ways to support community-based organizations to create affordable housing using new techniques and partnerships. This involved studying and documenting tenure and governance approaches, understanding what motivates private sector partners to support affordable housing, how hybrid models can provide affordable housing while meeting other social goals, and how community organizations can find strength in their balance sheets and other resources in order to build and maintain affordable housing. 


\section{$\underline{\text { Municipal Government Contact }}$}

3. Saide Sayah (Interview conducted on Nov. 15, 2017) length 2:01:08

Program Manager

Affordable Housing Unit

Housing Services Branch

Community and Social Services Department

City of Ottawa

Initiated the Roundtable on Affordable Housing for Older Adults

http://ottawa.ca/en/residents/social-services/housing

\section{Cohousing Development Contacts}

4. Kathryn McCamant (Interview conducted on Nov. 6, 2017) length 1:01:22

President CoHousing Solutions (cohousing development consulting services)

241B Commercial Street

Nevada City, CA 95959

www.cohousing-solutions.com

Book: Creating Cohousing: Building Sustainable Communities by Kathryn McCamant \& Charles Durrett. (also listed under Developers and Architects)

5. Ronaye Matthew (Interview conducted on Oct. 24, 2017) length 1:13:10

Founder and Principal of Cohousing Development Consulting (CDC), Burnaby, BC.

Founding member of the Canadian Cohousing Network

Cohousing member of Cranberry Commons cohousing since it's completion in 2001

R. Matthew has worked with cohousing groups throughout Western Canada and has developed legal, financial, organizational and marketing systems that are uniquely Canadian. She has been involved in the creation of most of the completed cohousing projects to date in Canada and is a major contributor to the growing success rate of cohousing in British Columbia. She is currently (2018) considered the pre-eminent cohousing development consultant in Canada.

6. Margaret Critchlow (Interview conducted on Nov. 8, 2017) length 1:45:33

Email: raincoast.home@gmail.com

Co-founding Director of Canadian Senior Cohousing Society

Professor Emerita York University

Associate with Cohousing Development Consulting (CDC) 


\section{Developers and Architects}

7. David Kardish (Interview conducted on Nov. 21, 2017) length 1:09:55 Vice-President, Land Development, The Regional Group (Developers)

Principal of Greystone Development

1737 Woodward Drive, 2nd Floor, Ottawa, K2C OP9

(repeat) Kathryn McCamant, Architect (Interview conducted on Nov. 6, 2018) McCamant and Durrett Architects

241-B Commercial Street

Nevada City, CA 95959

www.cohousingco.com

Architect and Project Manager of numerous cohousing projects

(also listed under Cohousing Development Contacts)

\section{Community Advocates}

8. John Johnson, Lawyer (Interview conducted on Oct. 20, 2017)

Past President of Board of Directors of Council on Aging of Ottawa

9. Carol Burrows (Interview conducted on Oct. 16, 2017)

Chair of Affordable Supportive Housing for Seniors

Strategic Implementation Task Force

United Way and Centraide Ottawa

613-228-6700 


\section{Appendix B}

Housing Organizations (plus descriptions of organizational mandates)

Ottawa Community Housing Corporation: provides and manages affordable housing for low to moderate-income households. In collaboration with their tenants and community partners they promote the development of healthy, diverse, sustainable and secure communities. The City of Ottawa is the sole Shareholder of Ottawa Community Housing (OCH). (June 2002, Ottawa Community Housing Corporation was so named following the amalgamation of two organizations, City Living and Ottawa Housing Corporation). Each of these housing Providers had over 25 years of housing experience.

Central Mortgage and Housing $(\mathrm{CMHC})$ : $\mathrm{CMHC}^{\prime}$ s mandate, as defined in the National Housing Act, is to: "promote housing affordability and choice, to facilitate access to, and competition and efficiency in the provision of, housing finance, to protect the availability of adequate funding for housing at low cost, and generally contribute to the well-being of the housing sector in the national economy." CMHC is a Crown corporation, reporting to the Parliament of Canada through a Minister, and governed by a Board of Directors which is accountable for the overall corporate governance of the Corporation. The Board of Directors is responsible for managing the affairs of the Corporation and the conduct of its business in accordance with the Canada Mortgage and Housing Corporation Act, the Financial Administration Act, and the National Housing Act.

Centretown Citizens Ottawa Corporation (CCOC) is a private non-profit housing organization with over 50 properties that provide over 1500 units of affordable housing to Ottawa residents.

\section{http://ccochousing.org}

Contact: Graeme Hussey, Development Manager Centretown Citizens Ottawa Corp (CCOC)

President of Centretown Affordable Housing Development Corporation (Cahdco).

Broadening the Base: established to enhance production of affordable housing, encourage philanthropy, social impact investment, repurposing of faith property, heritage regeneration...

- Social Impact Finance Charette and workshop on CMHC Funding

- Donor advised fund within the Community Foundation of Ottawa

- Development of a community bond that could be directed to affordable housing

- Partners: Mike Bulthuis (mike@endhomelessnessottawa.ca)

Randal Goodfellow (rrgoodfellow@gmail.com)

Chris Henderson (chenderson@delphi.ca)

Graeme Hussey (graeme.hussey@ccochousing.org) 


\section{Appendix C}

\section{Strategies for Creating More Affordability in Your Cohousing Community ${ }^{121}$}

(copied directly from Chris Scott-Hansen, Urban Cohousing Associates)

1. Internal down payment assistance (members operate as financers)

2. Outside down payment assistance

3. Second mortgages (member to member loan)

4. Co-purchase options

5. First time buyers

6. The reduced monthly condo fee subsidy.

7. Maintenance reserve reinvestment

8. Unit price buy down

9. Design for affordability - capital costs and operating costs

10. Shared units

11. Community owned rental unit

12. Participating non-resident owners

13. Purchase of one or more units by an outside affordable housing entity

1. Internal Down Payment Assistance: Assisting with the necessary down-payment, required by the primary mortgage lender, is done in a number of ways. A revolving Community Loan Fund can be established with funds from members of the group who have available assets to invest within the community. This can make those assets available directly to other individual households within the community, or to a cooperative fund. For this purpose, it should be administered by a volunteer group within the community, normally a finance committee, or an affordable housing sub-committee of the Finance Committee. Some groups arrange to have a third party administer this fund.

2. Outside Down Payment Assistance: In addition to the internal banking there are sometimes external down payment assistance programs available for specially qualified buyers. If you think you have members who may qualify you may want to ask for more information about these programs and/or help with research the current possibilities. As always, qualification will be based on making a commitment to being a part of the community.

\footnotetext{
121 Chris Scott-Hansen: “Creating More Affordability in Your Community: A Selection of Ideas," Urban Cohousing Associates, Inc., 2015, www.urbancohousingassociates.com. www.cohousing.org/node/2977 http://www.urbancohousingassociates.com/resources/affordable-cohousing/
} 
3. Second Mortgages: In addition to down

payment assistance, sometimes it can make sense to get a Second Mortgage. The two primary ways this is done are through;

a. Second Mortgage loans - direct, one member to another, above board, and visible to the primary mortgage lender. Some banks can provide a second mortgage, often at a much higher interest rate than the first mortgage.

b. Silent Second Mortgage loans - direct, one member to another, below the visibility of the primary mortgage lending bank. This allows the borrower to appear to have a larger down payment, allowing them to borrow more from the bank than would otherwise be able to offer. Since this is frowned on by the official bank lenders you may need to move this money to the buyer's savings account months in advanced to allow the money to "season" in that account.

4. Co-purchase Options: For most cohousing groups, there are buyers who find that it is feasible and more affordable for them to co-purchase their new home with another person or another household. Having common facilities and a strong sense of community is often what makes this possible. Sometimes the other party is another home owner within the community, and sometimes they are external friends or family. And sometimes the co-purchasers will occupy the new home together - sometimes called "tenants in common." In either case, the ownership is shared, the proceeds of the sale of the home is also shared if and when it is resold.

5. First Time Buyers: There are first time buyer mortgage programs that could help those who qualify by either reducing the down payment requirements, or possibly even eliminating the requirement for a down payment. If you think you may qualify, please ask for more information about these programs. Qualification will always be based on making a commitment to being a part of the community.

6. The Reduced Monthly Condo Fee Subsidy: Adopted by some cohousing communities, the idea here is that banks will grant mortgages based on the following formula: your total housing costs $=$ mortgage + taxes + insurance + monthly condominium fees may not exceed $\mathrm{x} \%$ of your gross annual income. If the condominium fees are removed or reduced, the bank can give the home buyer a slightly higher mortgage. Over the years, the total mortgage costs will remain the same, but because of inflation costs, the home-owner's income will usually rise, so that gradually, the homeowner can afford to pay the condominium fees. The removal of $\$ 150$ in condo fees will allow the buyer to qualify for something like \$20-30K more mortgage, often enough to allow a young family to buy that extra bedroom they need. If structured correctly, the cost to each of the non-subsidized households is only a few dollars each month in the initial year and may be reduced to zero in 5 to 10 years. 
Members may apply for a temporary removal of the monthly Coho (or Condominium) fees in order to qualify for a higher mortgage. Starting from the initial granting of the subsidy, the Coho fees will gradually rise, e.g.: a) in 5 annual steps of $1 / 5$ of the regular fees. After 5 years the member pays regular dues, or... b) in accordance with member's ability to pay, if member provides the Dearborn Commons Coho Business Association with income documentation.

7. Maintenance Reserve Reinvestment: All home owner associations need to establish a maintenance reserve fund to prepare for the cost of maintenance and repairs in the future roofs, hot water heaters, etc. Hopefully you won't need that money for 10 or 15 years since you chose to build a high quality, durable building. The reserve fund comes from an initial contribution by first buyers followed by monthly additional contributions. This fund, which can run as much as several hundred thousand dollars, is normally invested in bonds, or other safe interest-bearing securities.

Some of this money (NOT ALL OF IT) can be re-invested in your own community. By establishing a relatively large reserve fund up front you can make 1 ) internal subsidies (investments) are possible, and 2) lower monthly contributions to the reserve fund, lowering home owners' dues.

Some communities will invest a portion of this fund in its own members, through a buy- down subsidy. Your community can buy a portion of a unit (or, buy down the price of a unit) for a qualified member. Then, the member can repay this subsidy when his/her income allows, or when the unit is sold.

Since the units will be resold at market price the value of the original subsidy/ investment rises with the value of the property. When the investment is returned, the community can either reuse this money to subsidize other qualified households, or simply repay the reserve fund. The finance committee will have to determine whether to co-own the subsidized units, or simply subsidize them and the decision will need to be balanced with the prudence of tying up the resources from the reserve fund, evaluating long term liquidity needs.

8. Unit Price Buy Down: Members may apply for a reduced price on their unit, financed by a buydown subsidy provided by the rest of the membership. The price reduction will be determined by need according to certain criteria, including household size, and size of desired unit. At any time, a member can contribute an amount equal to initial portion of market price subsidized and thus buy themselves out of the obligation to return the subsidy upon sale of the unit. Otherwise, the member will return an amount equal to initial portion of market price subsidized proportional to the present market value of unit upon sale of the unit. 


\section{Design for Affordability-Capital Costs and Operating Costs: The project can be designed}

with affordability in mind. Simplicity and standardization are the goal to reduce capital costs (initial construction costs). In addition, making smaller units available will make your project affordable to more people - once they understand and believe in the value of the common house and how it can fit into and supplement their lifestyle. These smallest units might be located close to the common house to allow for convenient use of $\mathrm{CH}$ facilities as a supplement to the small units.

Designing for affordability also means building a durable, low maintenance project. Obviously, you want to reduce long-term operating costs. Of course, this competes with keeping capital cost down and a balance has to be achieved.

10. Shared Units: Other prospective members might be encouraged to consider sharing larger units, such as two bedroom "bi-master" suites. This can be done either as tenants in common (see 4. above), or as the owner-member renting to another resident-member. Obviously, the households sharing a large unit will have to share a private kitchen.

11. Community Owned Rental Unit: Some prospective members can't afford to purchase. You can greatly expand economic diversity in your community by allowing for one or two rental units. Note that this can negatively affect mortgage qualifications and insurance underwriting.

Some communities own a rental unit together as a community. This has to go in the original budget and must be accounted for in the original unit pricing. If you're building 25 units and one is going to be a rental the price of the 24 units that are for sale must be slightly higher, approximately $4 \%$ higher. As a community you will own that 25 th unit, and you will have rental income from it.

In some groups a subset of the membership, usually five or six households, come together, pooling their money to purchase a rental unit as a group. They act much like a investment club, managing their assets and receiving rental income. This needs to be approved as a strategy by the whole community since it can negatively affect mortgage qualifications and insurance underwriting for other owners.

12. Participating Non-resident Owners: Some communities allow outside investors to purchase units as rentals. When doing this we always hope that the purchasers can be participating nonresident owners who are engaged in the community but do not live there. As a community you will want to set a limit on this. There is some debate as to what number of rentals is healthy in a cohousing community. Four rental units in a 16 unit community seems to work fine. Again, this 
needs to be approved as a strategy by the whole community since it can negatively affect mortgage qualifications and insurance underwriting for other owners.

13. Purchase of One or More Units by an Outside Affordable Housing Entity: Some communities allow outside affordable housing entities to purchase units as rentals. As good as this might sounds it can be challenging to implement because agencies, church groups or affordable housing programs who are capable of buying one or more units will have certain rules and "strings" attached. They will also have a decision-making bureaucracy to be navigated, and they often take way too long to engage and make the necessary commitments. This needs to be approved as a strategy by the whole community since it can negatively affect mortgage qualifications and insurance underwriting for other owners. 


\section{Appendix D \\ Tool Kit of Interview Questions}

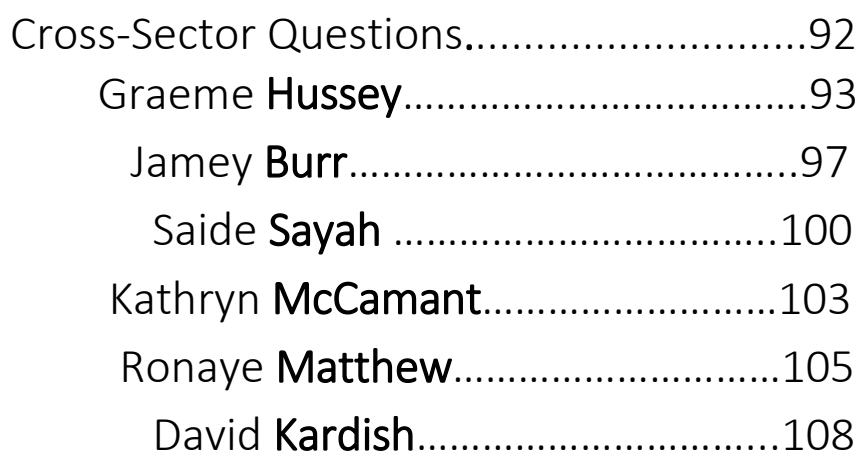




\section{Cross-Sector Interview Questions}

1. Have you played any role in your current position (or past positions) in promoting or supporting collective housing projects; cohousing projects in particular?

2. In your view, is cohousing a viable alternative model to the institutional retirement residence or old age home? Why, or why not?

3. What are the advantages and disadvantages of cohousing in comparison with other forms of housing for older adults? Is there anything that could mitigate the disadvantages?

4. What do you see as the major hurdles for groups wanting to create cohousing, and particularly cohousing for older adults?

5. Do you believe that you are more, or less, likely to be open to an approach regarding a housing project if it is organized and represented by women? Why is that?

6. What are the constraints on your capacity to make changes that could support cohousing projects?

7. Whose responsibility do you consider it to be, to address the needs of housing for the upcoming increase in senior housing?

8. Cohousing as an alternative model for senior housing is not currently on the public, or government, radar. What do you believe it would take to raise awareness within government policy? How can it end up on your desk? Who/where is it important for cohousing members to lobby?

9. What changes to public policy might empower and support groups looking to create cohousing? Looking at policy, programs, operations, and administrative procedures what could you imagine doing differently to support future directions for housing seniors?

10. Are there other observations you would like to make?

11. Are there other questions you think we should be asking about this topic? 


\section{Graeme Hussey Interview Questions}

Interview Date: Oct. 27, 2017

\section{Graeme's Role:}

1. How do you see your leadership role as the president of Cahdco, and the development manager for CCOC? What do you see as your main responsibilities and job descriptions for each? How do these two roles interrelate?

2. What was the path that led you to Cahdco, and to your role as president?

\section{Cahdco:}

3. Do other such 'non-profit development corporations' like Cahdco, exist in other cities for example in Vancouver, Toronto, Montreal, Halifax?

4. Cahdco serves as the development corporation for CCOC projects; what other non-profit organizations has Cahdco provided development consulting services to, and/or operated as a developer for?

5. How does Cahdco partner with designers and builders? Is there an RFP process? Is Cahdco ever approached by teams with a project already in mind?

6. (organizational question) How is Cahdco financed - what pays for it's operating budget? How is land for CCOC projects found; where does it come from? What are Cahdco's current priorities? How do priorities and mandates change/shift?

7. The mission statement on Cahdco's website states that you create partnerships with all levels of government, other non-profits and private industry to create new and innovative spaces of social benefit in Ottawa. Why does a non-profit cohousing group not fit within this mandate? What prevents a socially minded group of private citizens, self-organized into a non-profit organization, from creating a partnership with Cahdco?

8. Cohousing groups tend to have to re-invent the wheel with each new project; there is a need for a more unified and consistent approach to the creation of cohousing groups and projects. The many missteps, frustration, discouragement and loss of time and resources could largely be avoided if guidance from expert consultants was available. Would you consider supporting one of your staff to train as a cohousing development consultant with Ronaye Matthew of 'Cohousing Development Consulting'? 
9. What would enable Cahdco to support a group of self-organized citizens wanting to create a cohousing project? What, in your opinion, would increase the chances of such a group's success?

10. Does housing for seniors or the future needs of an older population figure in to any future plans of Cahdco and CCOC? Is this something that might be given consideration? Where would policy planning for seniors housing take place?

11. What does the 'Housing Services Corporation Regeneration and Asset Sustainability' of which you are a member, do?

\section{Policy}

\section{Re Seniors Housing:}

12. Given that a senior living in a cohousing community saves the health-care system and the economy around \$45,000 yearly for each individual senior, there is a strong economic incentive (not to mention social wellness) to begin to support such projects - why is this not happening? Seniors living in a cohousing environment tend to stay out of long-term care facilities for 8-10 years longer.

13. What would it take for the City of Ottawa or the Provincial Government to introduce a planning policy around senior cohousing that was not 'affordable' (not only directed to low-income persons)? Do you even see this as a future possibility? What might that look like?

14. What do you think it will take for policy advisors at all levels of government to begin to respond to a looming senior housing crisis? And to look for innovative solutions?

15. Has Cahdco or CCOC had any input to the National Housing Strategy? If it has, can you share what some of its recommendations were?

\section{Re Affordable Housing:}

16. What are the limited government housing capital programs that have returned (since the provincial governments withdrawal of funding for affordable housing in 1996)? How are these funds allocated? Has the provincial government started any other re-investment in affordable housing? 
17. Are you aware of public policy in other Canadian provinces that differs to that in Ontario; that might create incentives for groups of people wanting to organize a cohousing project?

18. Did the 'Promoting Affordable Housing Act' pass in the Ontario Legislature and get royal approval? ("requiring private sector developers to include affordable housing units in their developments through inclusionary zoning") What will this mean for the future of affordable housing and for the for-profit developers? When will this take effect?

19. What are some of the innovative financing structures and tools that are available for individuals of low to moderate income, to enter the homeownership market?

20. What new programs are you aware of that a cohousing group might qualify for?

21. What happened to the 'Broadening the Base' initiative? For what reasons was it not more successful?

\section{Cohousing Groups:}

22. The definition of 'affordable' housing - if a household's shelter costs are less than $30 \%$ of before-tax household income - seems very limited. Only $6 \%$ of Ottawa's population falls within this definition. There exist a diversity of affordable housing needs - a diversity of solutions and opportunities are needed. How can seniors on fixed incomes help to create their own solutions to their housing needs?

23. One of the biggest hurdles facing cohousing groups (especially those wanting to build urban projects) is how to secure land for the project; groups are in competition with long-time developers and organizations that have inside knowledge of existing land sales. Is there any way a cohousing organization can get advice or advocacy in finding such sites?

24. Could a cohousing project qualify for real-estate consulting services that would offer guidance and expertise to create a successful project? What would they need to do?

25. One of the biggest regrets of the Convivium cohousing group was, that those who could not afford to 'buy' a unit (or shares) dropped out of the group. How could we have 
been a mixed income (diversity of income) project with both ownership and rental units? Does this look different in a co-op model than in a condo model?

26. In a recent interview with Ronaye Matthews, founder and president of 'Cohousing Development Consulting' out of Burnaby BC, she stated the biggest challenge for groups trying to create a cohousing community is the complexity of the development process that requires much expertise. She has not known of any cohousing group that succeeded in building a project that did not have a cohousing consultant (one in Vancouver). Cohousing groups trying to create a project in Eastern and Central Canada do not have access to this kind of expertise. Ms. Matthews would be interested in training developers and others with backgrounds in architecture and building to become cohousing development consultants. Would Cahdco consider training some of its project managers in cohousing development?

27. What role do you believe the current 'development culture' (the culture of the developer) has in the difficulty for groups of citizens to create a viable project? By current development culture I mean to point to the model in the North American milieu that relies on developers to build projects (condos, townhouses, single family homes) for private ownership. 


\section{Jamey Burr Interview Questions}

Interview Date: October 31, 2017

\section{Policy}

\section{Re Seniors Housing:}

1. Given that a senior living in a cohousing community saves the health-care system and the economy around \$45,000 yearly for each individual senior, there is a strong economic incentive (not to mention social wellness) to begin to support such projects - why is this not happening? Seniors living in a cohousing environment tend to stay out of long-term care facilities for 8-10 years longer.

2. What would it take for the City of Ottawa or the Provincial Government to introduce a planning policy around senior cohousing that was not 'affordable' (not only directed to low-income persons)? Do you even see this as a future possibility? What might that look like?

3. What do you think it will take for policy advisors at all levels of government to begin to respond to a looming senior housing crisis? And to look for innovative solutions?

4. National Housing Strategy: what would you have given as input re seniors housing if you had been asked for input?

\section{Re Affordable Housing:}

5. What are the limited government housing capital programs that have returned (since the provincial governments withdrawal of funding for affordable housing in 1996)? How are these funds allocated? Has the provincial government started any other re-investment in affordable housing?

6. Are you aware of public policy in other Canadian provinces that differs to that in Ontario; that might create incentives for groups of people wanting to organize a cohousing project?

7. Did the 'Promoting Affordable Housing Act' pass in the Ontario Legislature and get royal approval? ("requiring private sector developers to include affordable housing units in their developments through inclusionary zoning") What will this mean for the future of affordable housing and for the for-profit developers? When will this take effect? 
8. What are some of the innovative financing structures and tools that are available for individuals of low to moderate income, to enter the homeownership market?

9. What new programs are you aware of that a cohousing group might qualify for?

\section{Cohousing Groups:}

10. The definition of 'affordable' housing - if a household's shelter costs are less than 30\% of before-tax household income - seems very limited. Only 6\% of Ottawa's population falls within this definition. There exists a diversity of 'affordable' housing needs $-a$ diversity of solutions and opportunities are needed. How can seniors on fixed incomes help to create their own solutions to their housing needs?

11. * One of the biggest hurdles facing cohousing groups (especially those wanting to build urban projects) is how to secure land for the project; groups are in competition with long-time developers and organizations that have inside knowledge of existing land sales. Is there any way a cohousing organization can get advice or advocacy in finding such sites?

12. * One of the biggest regrets of the Convivium cohousing group was, that those who could not afford to 'buy' a unit (or shares) dropped out of the group. How could we have been a mixed income (diversity of income) project with both ownership and rental units? Does this look different in a co-op model than in a condo model?

13. In a recent interview with Ronaye Matthews, founder and president of 'Cohousing Development Consulting' out of Burnaby BC, she stated the biggest challenge for groups trying to create a cohousing community is the complexity of the development process that requires much expertise. She has not known of any cohousing group that succeeded in building a project that did not have a cohousing consultant (one in Vancouver). Cohousing groups trying to create a project in Eastern and Central Canada do not have access to this kind of expertise. Ms. Matthews would be interested in training developers and others with backgrounds in architecture and building to become cohousing development consultants. Would you consider training as a cohousing development consultant? 
14. What are the most productive ways to work with the private sector? Can you explain public-private partnerships; what might that look like for a cohousing group?

15. What role do you believe the current 'development culture' (the culture of the developer) has in the difficulty for groups of citizens to create a viable project? By current development culture I mean to point to the model in the North American milieu that relies on developers to build projects (condos, townhouses, single family homes) for private ownership. 


\section{Saide Sayah Interview Questions}

Interview Date: Nov. 15, 2017

\section{Affordable Housing Unit:}

1. What does your role as Program Manager of the Affordable Housing Unit of the City of Ottawa consist of? What are the priorities of the department at the moment? How do these priorities get set?

2. The Affordable Housing Unit works with local partners and local agencies. Can you give me some examples of who these partners are? How do these local partners or agencies come to work with AFU? How are they chosen?

3. The Affordable Housing Unit's task is to facilitate, fund and develop affordable and supportive housing; why is a senior cohousing project not considered a supportive housing project?

4. What other departments exist in the Housing Services Branch of the City of Ottawa? Are there any units that address issues of senior housing for moderate-income seniors (not just low-income seniors of which only make up 6\% of seniors in Ottawa? If attention was to be paid to this sector of the population, within what office/department would it be addressed?

\section{Cohousing:}

5. In the introduction to your LinkedIn profile you mention the importance of supporting community efforts to build sustainable and resilient neighbourhoods. Cohousing is a community led initiative that seeks to foster living in community, sustainable building approaches, integration with community services, and creating a co-care environment that would save the Health Care system a great deal of money. In your opinion why is this model of housing not receiving any consideration?

6. What rules and regulations of the City of Ottawa could affect a cohousing project? For example, Convivium, would like to build an apartment style building (3-4 storeys) of 2025 units (this could also end up being a renovation or addition to existing building).

7. What could the City of Ottawa do to facilitate a cohousing project? Other cities have leased land, reduced taxes, and partnering to create more affordable home ownership. What programs currently exist, or could exist in the future, that might be able to support Senior Cohousing now or in the future? 
8. Could there be any long-term lease opportunities on City-owned land (at nominal rates) that could help cohousing communities reach average market rents on expensive urban land? This is one of the biggest hurdles for an urban cohousing community - finding land!

9. Why could not some of the incentives listed on your website for affordable housing development not also exist to support senior cohousing projects? (see list in red in printed document)

\section{City of Ottawa:}

10. Can you explain the relationship that the City has with $\mathrm{CCOC}, \mathrm{OCH}$ and Cahdco?

11. Does the City have any policy of assistance for housing co-operatives? What about equity co-operatives? Any wider policy for senior's housing?

12. Is there any program that addresses projects wanting to utilize sustainability principles and an energy efficient approach?

13. Action Ottawa aims to increase the supply of low-income affordable housing and facilitate mixed-income communities. How does it hope to support mixed-income communities? Could this include support for low to moderate-income seniors to live in a cohousing community? What might it look like to integrate 4-5 affordable units into a market rate cohousing community?

14. I understand that at one time the City of Ottawa had an Affordable Home Ownership Program. How long was it in use? When was it cancelled and why? How did it work? Did it cost the city a lot of money? Could it be brought back? What could we do to lobby for it? Moderate-income seniors with some equity, wanting to live in a cohousing community, would need this to be able to buy into cohousing communities. What is the 'Affordable Homeownership Down Payment Assistance program? Could this be applied to buying a unit in a cohousing project? Would it make a difference whether the unit was a condo unit or a co-operative unit share?

15. Zoning and zoning bylaw changes in residential neighbourhoods could support low-rise senior cohousing projects? How could initiatives like this be considered? 
16. How are the programs that receive funding chosen? Who sets the policy and decides on the programs? What are the priorities for the City right now? How do those get changed? Who/how does one lobby?

17. In your opinion what are some of the contemporary planning issues facing the City of Ottawa currently?

18. What are the eligibility criteria to be placed on the affordable-housing list?

\section{Closing Questions:}

19. National Housing Strategy - Did you have any input into its recommendations? It appears that Homelessness, Indigenous housing, and purpose-built rentals are all addressed, but there is very little if anything that addresses the future housing needs of seniors. Nothing dealing with home ownership or rental as a senior? Do you know what agreements are being asked for by existing co-operatives? What about new cooperatives?

20. It appears that the lowest-income seniors will be housed in 'affordable housing' (only 6\% of Ottawa seniors will qualify) or 'long-term care' homes (if they can get in - long wait lists). The wealthiest will have the option of moving to privately run 'old-age residences' (4000-6000 a month) - there will be those who spend all of their life's saving on such residences leaving nothing as a legacy to their families. The moderate-income senior has not been addressed. Some $70 \%$ of seniors will not be able to afford the cost of a 'private residences' and will not qualify for affordable housing. How will the needs of these seniors be addressed?

21. It is often the older single woman who lives alone - often isolated and vulnerable to depression. Housing is not just about a roof over your head - isolation, depression, illness all result from a disconnection from community. The quality of life of senior women (for 20-30 years after age 65) needs serious consideration. What can be done to support alternative housing approaches for moderate income seniors, especially single women? Cohousing holds great promise in this regard; what could governments do to support such initiatives?

22. If you were to give advice or guidance to a group of seniors wanting to create cohousing, where would you suggest they lobby for support? 


\section{Katie McCamant Interview Questions}

Interview Date: Tuesday, Nov.6, 2017

1. One of the reasons given for the fact that there are so few cohousing projects in Canada at this time is that the cohousing development process is very complex and challenging, and that cohousing development expertise is not yet available in Eastern Canada. What does a cohousing development consultant need to understand, or have expertise in, that a regular development consultant may not have to know?

2. In your opinion what are some of the most common reasons that groups coming together to create a cohousing project, fail? (inverse question next) What do you think are the most important ingredients in creating a successful cohousing project?

3. Many sectors of the building industry, including conventional developers, are still largely male-dominated preserves; in your opinion, are the organizational structures of the building sectors in any way responsible for some of the challenges of creating a cohousing project? As a woman developer do you need to approach these structures more strategically with an eye to their existing characteristics?

4. It appears that there are a greater number of women, than men, advocating for the senior cohousing lifestyle? What reasons might explain this imbalance? Is this only a reflection of the demographic imbalance in the senior population? Do you see any evidence that it is mostly women who tend to initiate, organize and lead cohousing groups?

5. Could you speculate as to why it is that most cohousing developing consultants here in Canada, and in the US, tend to be women? Do you think that these consultants, as women, work differently than men working as development consultants?

6. A cohousing project is initiated by private citizens taking responsibility for their own housing and lifestyle choices; this is quite different to the conventional model of young couples or individual families buying into a condo or housing development, designed with the 'no-name' buyer in mind. In your opinion does having to consider the needs and desires of many real-life clients add to the challenge of creating cohousing? Does the conventional model of developer housing work against the cohousing model? Why? How? Is it possible to create collaboration between these very different intentions? 
7. What is your opinion regarding seniors- only cohousing as differentiated from the diversity of multi-generational cohousing? What might be the arguments for creating seniors-only cohousing?

8. One of the biggest regrets of Convivium was the need to exclude a number of lower and moderate-income residents who wanted to live in cohousing but could not afford the price of a unit (or shares for a unit). Can you think of any models in which this demographic could be included in an urban cohousing project with others who can afford the price of a unit?

9. Most cohousing in Canada, to date, has made use of the condo-strata ownership model; is this the case in the US? Are you aware of any cohousing projects in the USA that have used an equity co-operative legal model? Why has the condo model been the preferred legal structure? Are banks in the US willing to give loans and mortgages to cohousing groups using a co-operative structure?

10. Whose responsibility do you consider it to be, to address the upcoming increased need for senior housing alternatives? What might this actually look like at the policy/planning level? Is there any public funding available in the USA for senior cohousing (or just cohousing projects in general)? What level of Government is responsible for senior housing? (Federal, State, Municipal?) How are cohousing projects funded in the USA? Are lower to moderate income seniors able to afford to live in cohousing projects?

11. In the many years you have lived in a cohousing community yourself, what have been some of the most challenging moments/times as a community member?

12. What are some of the lessons you have learned in your years of working as acohousing development consultant? What are some of the things that you do differently now than you might have in the early years of your career? 


\section{Ronaye Matthews Interview Questions}

Interview Date: Tuesday, October 24, 2017

1. In the many years you have lived in a cohousing community (Cranberry Commons) yourself, what have been some of the most challenging moments/times as a community member?

2. How did your own personal interest in cohousing come about? How did your interest in living in cohousing evolve into creating a cohousing development consultancy?

3. Are there other cohousing development consultants offering services in Canada at present? Are you the only one? Are there any that you are aware of in Eastern Canada?

4. You stated in a CBC interview of 2008 that one of the reasons that there were so few cohousing projects at that time in Canada, was that the development process of a cohousing project is very challenging. What has changed in the last 10 years to allow for more cohousing projects in British Columbia to succeed now? Could you speculate as to why so many projects are being built out west and hardly any in Eastern Canada?

4b. You have also stated "we have to find ways to make it easier"; have there been any changes that have made the development process any easier?

5. In your document, 'What it Takes to Develop a Cohousing Project', (and your Company Profile document), the complex task of developing a cohousing project is outlined. Why is it that the complexity of creating a cohousing project is more of an issue than say, the complexity of the developer-driven conventional housing neighbourhood?

6. The cohousing project is initiated by private citizens taking responsibility for their own housing and lifestyle choices; this is quite distinct from the conventional model of young couples or individual families buying into a condo or housing development that has been designed with the 'no-name' buyer in mind. In your opinion does this ad to the challenges facing a group of people trying to create a cohousing project? Does the conventional model of developer housing work against the cohousing initiative?

7. In that same interview you pointed out that it is not easy to retrofit an apartment building to a cohousing project due to the design intentions of both being so different. Based on this observation, would you caution those looking to create a cohousing project against trying to recreate a cohousing project out of an existing condo or apartment building? 
8. Some groups of people would like to create senior cohousing in an urban setting where the cost of land will dictate an apartment style building typology; how do you create a 'village' in an apartment style building?

9. What is your opinion regarding seniors-only cohousing as differentiated from multigenerational cohousing? Do you see any arguments for creating seniors-only cohousing?

10. As you have pointed out, most cohousing to date have made use of the condo-strata ownership model; are you aware of any cohousing projects in Canada that have used an equity co-operative legal model? Why is the condo model the preferred legal structure?

11. It appears that there are a greater number of women, than men, advocating for the senior cohousing lifestyle? What reasons might explain this imbalance? Is this only a reflection of the demographic imbalance in the senior population? Do you see any indication as to whether it is mostly men or women who tend to initiate, organize and lead cohousing groups? In your opinion is there any pattern here?

12. Re Policy: You are likely aware that the federal government has been soliciting input on its 5-year National Housing Strategy; what do you think could/should be included in such a strategy that could benefit seniors trying to develop innovative housing projects?

12b. Have you personally, or CDC, had any opportunity to give direct input in this Strategy?

12c. What is your thinking around possible government support for cohousing projects? What might that look like? (eg. resources such as loans, grants, legitimizing cohousing?) For example, might they offer subsidies to pay for her services, or money for training more people in cohousing development consulting across the country?

13. Convivium Cohousing, here in Ottawa, has not had the benefit of working with a cohousing development consultant; as far as we are aware there are none working in eastern Canada. We are on our third try at jump starting this cohousing project: we have been through one turnkey proposal with a developer; we put out an RFP for a developer with land (brought 2, neither was acceptable location); we are now looking for land with the help of a real-estate broker and are in process of choosing a design/build team. 
3b. Is there anything you can recommend that would be helpful for communities like ours that are struggling along, learning as we go? Is there anything your company would be able to offer that could support groups not based in the West?

14. One of the biggest regrets of Convivium was the need to exclude a number of lower and middle-income earners who wanted to live in cohousing but could not afford the price of a unit (or shares for a unit). Can you think of any models in which this demographic could be included in an urban cohousing project with others who can afford the price of a unit?

15. Why is the condo structure the most popular legal model for cohousing in Canada? Why is the co-op structure such a difficult model to work with? 


\section{David Kardish Interview Questions}

Interview Date: November 21, 2017

1. What does your current role as Vice President of Land Development for Regional Group entail? If you were to create a 'job description' for your work what would it look like? How is it that you became part of Regional Group?

2. Have you played any role in your current position (or past roles) in addressing or supporting senior housing projects; cohousing projects in particular? What has been your level of involvement in senior housing issues? In whose interest was your involvement?

3. *What do you see as the advantages and disadvantages of creating a cohousing project in comparison with other forms of housing for older adults? Is there anything that could mitigate the disadvantages? In your view, is cohousing a viable alternative model to the institutional retirement residence or old age home? Why, or why not?

4. *What do you see as the major hurdles for groups wanting to create cohousing, and particularly cohousing for older adults?

5. *Whose responsibility do you consider it to be, to address the upcoming increased need for senior housing alternatives? Is there a role for government assistance? What might this actually look like at the policy/planning level (might it include funding sources, subsidies, or land grants)?

6. It is widely accepted that both the financial sector and the development industry are still male dominated fields; what is your opinion on whether this has any impact on attempts by senior women wanting to create a senior cohousing project in approaching these sectors for assistance in creating a cohousing project?

7. It appears that the lowest-income seniors will be housed in 'affordable housing' (only 6\% of Ottawa seniors will qualify) or 'long-term care' homes (if they can get in - long wait lists). The wealthiest will have the option of moving to privately run 'old-age residences' (4000-6000 a month) - there will be those who spend all of their life's saving on such residences leaving nothing as a legacy to their families. Some 70\% of seniors will not be able to afford the cost of a 'private residences' and will not qualify for affordable 
housing. The housing needs of moderate-income seniors have not been addressed; how do you envision the needs of these seniors being addressed?

8. National Housing Strategy: It appears that Homelessness, Indigenous housing, and purpose-built rentals are all addressed in the new National Housing Strategy, but there is very little if anything addressing the future housing needs of seniors. Nothing dealing with home ownership, or rental for seniors? Cohousing as an alternative model for senior housing is socially and financially viable. What might it take to raise awareness of the many opportunities that cohousing offers? Who/where is it important for cohousing members to lobby? What recommendations would you make to the government for its NHS, if you were asked?

9. It is often the older single woman who lives alone - often isolated and vulnerable to depression. The quality of life of senior women (for 20-30 years after age 65) needs serious consideration; isolation and depression are symptomatic of a disconnection from community. What can be done to support alternative housing approaches for moderate income seniors, especially single women?

10. Are there other observations you would like to make? Are there other questions you think we should be asking about this topic? 


\section{Appendix E \\ Transcripts of Interviews with Experts}

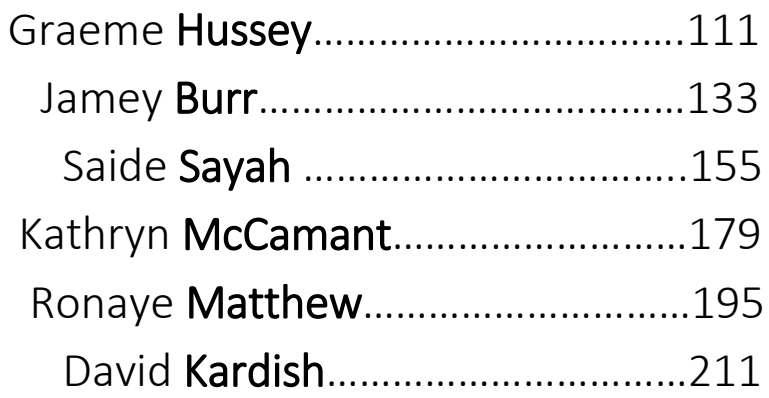




\section{Interview with Mr. Graeme Hussey}

President of Centretown Affordable Housing Development Corporation (Cahdco)

Development Manager for Centretown Citizens Ottawa Corporation (CCOC)

Interview conducted on October 27, 2017 (length 1:12:01)

Lynn Pfeffer: How do you see your leadership roles as the president of Cahdco and the development manager for CCOC: What do you see as your main responsibilities for each (a job description for each)? How do these two roles interrelate?

Graeme Hussey: $\quad$ Maybe I'll explain how CCOC and Cahdco interrelate because that might not be quite clear. I have two job titles, one for each of them and the one for CCOC has changed. I'm now the Director of Housing Development for CCOC and the President of Cahdco, but Cahdco is the development department of CCOC. I am the leader of that development department, therefore I'm the leader of Cahdco. We created Cahdco, just over 20 years ago to protect the legal liability of CCOC's assets.

What happened in the early to mid 1990s, is that Mike Harris became the premier of Ontario and he cut the programs which helped enable affordable housing, and it came after... the late eighties and early nineties was the heyday of affordable housing development under Bob Rae and Peterson. There were lots of programs, and lots of housing, and the province promoted the not-for-profit sector, and promoted them becoming kind of self-sufficient.

They said, "right now you might have some housing you operate - but, think of yourselves also as developers and create that internal capacity...". Dennis was in my role at that time and was the person who created Cahdco when he was the managerhe was the Coordinator of the CCOC Development Department, all the same kind of role but the title has changed.

They encouraged groups like CCOC to hire people like Dennis, rather than hire consultants to do that, and create that internal capacity. Then Harris came and cut it all. CCOC's DNA is best described as a community enterprise, with an emphasis on the entrepreneurial part of it.

It has been entrepreneurial from the beginning and when Harris cut - and I can go back and explain some of their examples, but as it relates to Cahdco, when Harris cut the programs they said, "there's no way we're cutting our capacity to do development - 
governments are governments, one comes, one goes, eventually there'll be one that has programs". Our mission at CCOC is to create, promote and maintain affordable housing and it's always been that.

We've never changed our mission, and each of those are equally important. That's why you'll see CCOC taking the leadership position when there's advocacy at City Hall around planning policies, or the 10-year housing plan. We always think we punch above our weight when it comes to spending resources on advocating, rather than just what we're paid to do by our tenants, which is to operate housing.

The maintenance of housing is a big part of it, and one thing that we're really well known for is being almost like a landlord of choice, people are proud to live at CCOC, whether they're a subsidized tenant, or a market tenant because anybody can live at CCOC in our model.

The creation of housing was the other third kind of tenet of the mission and that was equally important. It wasn't satisfactory from the board's perspective in the early to mid-nineties to just give up on doing development, and they knew if they laid off the internal capacity, (i.e. even just having one person thinking about it and dedicated to it) that it's hard to resurrect that, it's hard to bring it back, once you get rid of something. Particularly in a non-profit setting where money is always limited.

Lynn Pfeffer: That's an interesting point.

Graeme Hussey: You know, even relating it to a project, if you have something that you could describe as a "value-add" to the project, let's say it's an amenity room, once you take it out of the design it's hard to put it back in. Once you cut the cost from the budget it's hard to reintroduce it. If you're looking for something to be absolutely critical, it's better to keep it in there rather than pull it out and see, "Oh if we have the money later on we'll put it back in"; you won't. They had that same philosophy. "If we cut our development staff. and lay Dennis off. we're never going to have development staff again". And so, they created Cahdco.

The idea was CCOC will be able to continue to do 'some' new development, but it won't be 'as' affordable because there's no government program to support it and there won't be 'as much', and overall, that won't be enough to substantiate having this person fulltime there; they're going to be bored, so let's do some other things. They did some 
studies for CMHC, they wrote some reports, they got a few grants, just to piece together some revenue to offset the cost of the people.

And then they thought, well why don't we...if others are laying off their staff, they still might be able to do a project, maybe not as affordable, but they might need to hire somebody, so why not hire us instead of a private consultant, because they've laid off their capacity.

And then, thirdly, if you thought of Convivium as affordable homeownership, you know there are ways, or alternatives to the typical affordable housing project, maybe there are projects that we can create, or work on, that are in that basket that don't traditionally involve government grants like social affordable housing does, that can work in between all of those. We piece together some fee for service, some of our own staff to keep those people busy to pay for the cost to maintain the capacity, and that was the original emphasis of creating Cahdco.

With CCOC having all these apartments, and development always being risky sometimes projects end up with legal law suits, or there's that legal risk right-and so we didn't want to ever have our apartments that CCOC owned exposed to that, so we created a corporation to do that. But it was just the development department of CCOC, that was what Cahdco was.

And we had some modest successes, so that's from 1996 to 2009. For those 13 years we had modest successes. We did an affordable homeownership condo called Clarence Gate, we did a couple projects with Salus, we did a couple CCOC projects, and a couple others. We did some projects for City Living, which became Ottawa Community Housing. Ottawa Community Housing was the merger of the municipal non-profit housing which was City Living, and the regional non-profit housing - they merged to create $\mathrm{OCH}$.

Before OCH was created, Cahdco existed, and we were the development consultant to City Living which was half of $\mathrm{OCH}$, is half of $\mathrm{OCH}$, right. We did all of that, we had modest successes.

Then the programs got renewed in 2008 when Paul Martin was the Prime Minister and McGuinty was the Premier, and it happened because Jack Layton, who held the balance of power when Paul Martin was the Prime Minister, negotiated certain things for Martin - through one budget - to maintain his position. One of the things that Jack 
Layton negotiated, or the NDP negotiated, to keep them in power, was that they had to reintroduce the affordable housing programs.

They did that, and then negotiated it with each of the provinces and when the money shook out under these new programs - it's called by the federal government the Investment in Affordable Housing Program (IAH) - it's the program that feeds money into that Action Ottawa program, locally.

Action Ottawa, when it got its first money through the IAH program from the federal government, took that money and put it into an Action Ottawa RFP for the Beaver Barracks site. We won that competitive RFP, CCOC. The reason why we won is because we had been doing projects all along, we had that capacity.

At that point the Beaver Barracks is CCOC's biggest project, it's one of the biggest affordable housing projects in Ottawa's history. The holistic entity of Cahdco/the CCOC's development department - aka all the capacity that we have for developmentwent into the Beaver Barracks, and wasn't looking for other clients, or other projects, whether it was for CCOC or other groups.

Actually, at the moment where we began construction on the Beaver Barracks, Dennis Carr moved to Vancouver and was replaced. He went out, and for about five years was the senior staff at the city of Vancouver responsible for affordable housing and what they called Social Facilities Development, daycares, community health centres.

He was the person who had the money, that gave it out to the not-for-profits and the other groups that created the Olympic projects. He came back in time when we were finishing the Beaver Barracks; kind of interesting because it was about five years construction.

There was somebody in Dennis' role between Dennis and I; they managed during the Beaver Barracks. I got hired on part way through the Beaver Barracks, in a junior role. That person left, and I got promoted into that role of manager of CCOC development department and leader of Cahdco just as we had finished the construction of the Beaver Barracks. A flagship project, and we had no next project, and Cahdco had no clients.

Lynn Pfeffer: Really? When is this now? 
Graeme Hussey: $\quad$ This was 2013. But we had just finished a flagship project. The Cahdco side of this had basically been dormant during the Beaver Barracks. The corporate entity still existed, it is a not-for-profit, it had a board of directors, but it didn't create any projects, it wasn't looking for land, it wasn't looking for clients. But you know, there were government programs; there wasn't, and still isn't, a lot of competition to Cahdco, there's not a lot of groups that cohousing groups can hire.

There's none that are not-for-profits; if there is, they're usually individuals. Most of them are looking to retire. Many of them were the 'Dennises' who started in the late $80 \mathrm{~s}$ and early 90s, in the heyday, and then they've branched out and maybe they worked for one level of government, or not, maybe they became private consultants, but now they're at that age of retirement, or even somebody like Phil Brown. He died, the year before last. I think Convivium might have interviewed Jackson-Brown...Joanne Jackson is the name - that was Phil's wife. He's the Brown part of it, so they were life partners and business partners, but he passed away maybe now two years ago.

Just to say that we re-invigorated Cahdco, sometimes we call it Cahdco 2.0, in and around 2013, just after we finished the Beaver Barracks. We went to the existing board members, which was only five, it was a small board, now there's eight, and we did a strategic planning and business planning exercise with them. From a strategic planning perspective, we laid out some options, everything from dissolve Cahdco - because CCOC can still do its own development, it can keep Graeme. We had no other team members, there was just me, now there's nine going on 10. Dennis was about to move back to Ottawa, so we saw that as a strategic opportunity, just like we had finished this flagship project. A lot of people wanted to talk to us and we were the centre of attention. And so, everything from dissolve Cahdco; CCOC can continue to do its own development, Graeme will be the manager of the development department, just Cahdco won't do projects for others.

\section{Lynn Pfeffer: Just for CCOC?}

Graeme Hussey: Just for CCOC, we considered everything, including: we've got this mission, which is to be a non-profit real estate development corporation for CCOC and others, and for ourselves, and we can put more "investment" into that and create more capacity, which is really hiring more staff, trying hard to find more clients and projects; and a couple options in between, of how vigorously to approach those two spectrums. 
Our board is formed by - the membership of Cahdco as an organization is CCOC the corporation, and the board of directors.

Cahdco is a not-for-profit that is federally incorporated, we can work anywhere in Canada, and - because non-profits are membership based - our membership, according to our bylaws, is the CCOC corporation, and the board of directors of Cahdco. In our bylaws a majority of the board is appointed by CCOC, and the other minority is appointed by the Cahdco board and they're only a board member-here's the overall thing you need to know, CCOC appoints the board of Cahdco, CCOC controls Cahdco through the bylaws. We do have a board and there's experts in development, but they're appointed by CCOC and I am a senior staff member of CCOC. My boss, who's the executive director of CCOC, who is one of the board members of Cahdco, appoints the rest of the board. There's no election, there's no open membership. I'm like the CEO. President, CEO, that's what that title means.

Lynn Pfeffer: Where did the money come from at the time when you decided to increase the resources of Cahdco? You said, "one of the things that we decided was we were going to hire more staff, look for more clients"; how did you make that transition?

Graeme Hussey: Basically, what Cahdco is, in terms of a governance, is an appointed board by CCOC. It's controlled by CCOC. You can call it a subsidiary, but CCOC as a not-for-profit has no share capital, it can't be technically called a subsidiary, so sometimes we say sister-corporation.

The people are all employees of CCOC. I'm an employee of CCOC but-my salary, my benefits, all that kind of stuff is paid for by Cahdco. Basically, Cahdco has an intercorporate agreement with CCOC and the costs to run Cahdco, all the CCOC development department, all their salaries, we even pay CCOC rent to use this space, all that is paid for by Cahdco.

Cahdco pays for its costs through revenues it generates from primarily providing development consulting to our clients, which includes CCOC. When we work on a project for CCOC we have a contract with them, just like we have a contract with Convivium, and it states what our services are, what we're providing to CCOC, how much it's going to cost and what are the terms. It is the same as any other client.

The simple answer is Cahdco is a fee for service consulting firm and it gets revenues by having clients, and we pay for that through those revenues. Now a little bit of your 
question is about cash flow, right, because it's what comes first, the chicken, or the egg; did you get a bunch of clients that were giving you money first before you hired the staff, or did you hire the staff before you get the clients - and it's a little bit of both. It's never simple, and it's like the clients and projects can come like this, but the staff comes like that.

We cost a whole - me and all my staff costs, but a client like Convivium they don't necessitate having a whole staff. You hire staff and you might get more than one project's worth of capacity, but the projects and the clients come in one by one and sometimes the projects - we got three clients, or three kinds of contracts new in the last month, and we submitted proposals to those groups two to three years ago.

Sometimes it takes a long time before we get our contracts signed, let alone before a project happens in terms of shovel on the ground. There's a lot of that and we're like a business, where it's unpredictable revenue, that's real estate in general.

Lynn Pfeffer: Does this model of not-for-profit development consultancy exist anywhere else in Canada?

Graeme Hussey: $\quad$ There are not a lot of not-for-profit development corporations, but there are consulting businesses.

Lynn Pfeffer: Those wouldn't be 'not-for-profit' though, right?

Graeme Hussey: $\quad$ Not really not-for-profit. There's 'for-profit' consulting businesses, so Convivium can hire a for-profit, or they could hire us. But there are groups that -in effect we're just a consulting business as our clients are related to us. But often when I describe Cahdco I say we are three baskets, but in those basket, we do the same tasks, or activities.

One of the baskets is we do the development for CCOC, another basket is we do the development for others, and the third basket is we do our own; and the tasks and activities are what I would just broadly call development tasks._You know, they're project management; they're helping to secure land, money, and building the capacity of groups - they're generally the same.

But those are the baskets, and CCOC pays us to do theirs, our clients pay us to do theirs, and the Cahdco part is like us being our own private developer, we want to do 
our own projects, where we buy the land and we-Deschâtelets is an example of that, you know it's a Cahdco led project. In the end it might be like a condo model where we don't operate it, but we're the one who buy the land and takes the developer risk.

To finish answering your question about how we did the transition - we have a sister corporation who has more financial capacity than we do, and they helped us with our cash flow with an inter-corporate loan. This is not free money, but it helps.

Lynn Pfeffer: Yes, and you are interconnected, so any of the - not profits, your resources, can feed back through that too.

Graeme Hussey: $\quad$ That's right, exactly, there's a lot of symbiosis.

Lynn Pfeffer: This brings up something, that relates to cohousing projects in general, but it is also part of my concern in terms of the challenges that Cahdco faces in projects.

I was interviewing Ronaye Matthew the founder and principal of Cohousing Development Consulting, out of Burnaby, British Columbia. I believe that she has been doing this now for 15-20 years. There are maybe seven, or eight cohousing projects in British Columbia, all of which she has been the development consultant/manager on. She's currently working on four projects. She's the only dedicated cohousing development consultant in Canada, other than a small firm, called Communitas, which operates out of Alberta.

She stated that the development process is so complex that that's really the major hurdle in terms of any group getting through this process.

Margaret Critchlow (one of her facilitators) said 90\% of groups that try to form cohousing projects fail; and Ronave said she's never seen a cohousing group succeed that didn't have a professional development consultant related to cohousing - a 'cohousing development consultant.' It therefore follows that any cohousing group wanting to create a project in the city of Ottawa should be looking to hire a 'cohousing development consultant', but there are no cohousing development consultants to hire in Eastern Canada.

I have two questions that come out of that: is Cahdco in a position to take on a cohousing project and develop it? Would that come under the client section of what you have described? Or the private development section? What's the difference? 
Graeme Hussey: Absolutely. The cohousing group as client of Cahdco is someone hiring us as a development consultant; Cahdco as the private developer - building a cohousing project as a 'Cahdco project' - is us being a partner, a development partner. Development partnerships are sharing the financial risk and sharing the financial reward.

Lynn Pfeffer: Can you say more about that, what does that really mean?

Graeme Hussey: Well, I'm not sure how it applies to a cohousing group necessarily, but just to say that we did a project called Clarence Gate, which is a condo development where we were the developer. We bought the land, we sold the units and we walked away. *Theoretically the cohousing group is like the buyers. And there's no reason, kind of conceptually, that we couldn't do a project where we were like the condo or cohousing developer (I use that interchangeably, that's just the corporate structure) where we ended up selling the units as a group package or something.

We've never done something like that, nobody else has in Ottawa because there's no other cohousing groups, except for the one (Terra Firma), but they did it on their own. I'm open to that possibility. To be honest I'm not sure if that's a benefit to a cohousing group, or whether it would be better to just hire us as a consultant.

Lynn Pfeffer: What would be the difference then between the two -what's the scope of things you could offer a cohousing group if they are your client, versus the scope of things that you offer if you're doing a private development partnership? I'm trying to understand the difference between when a client group comes to you and says, "We need help", or a client group comes to you and says, "Would you do a development partnership with us"?

Graeme Hussey: $\quad$ Cahdco as the developer doesn't happen as much, in the sense of what we're talking about. It's something Cahdco is trying to develop, *but it's difficult, mostly because nobody pays us to do this. This is us putting in time and energy and maybe you're getting money, or maybe not. The model of a group as our client, is somebody's come to us and says, "Here's the money to do the work".

All of our efforts end up getting focussed on the non-profit clients because people are paying us, and there are deadlines, and Cahdco as the developer is the research and development arm of a company - but it's something strategically where we're trying to 
put more effort. But conceptually in the model with the consultants, the cohousing group is the one that bears all the risks.

In the model where Cahdco is the developer, the group might be able to transfer their risks over to a third party, but you pay more for that. If you transfer risks, it costs money. So theoretically, in the model where we would do a development partnership if Cahdco was able to manage the risks - we would make much more money than we would in a project where the cohousing group was a client. If we aren't able to manage the risks, we might lose money. Cahdco can even lose money, just like a private developer doesn't always make profit, it could lose money.

Lynn Pfeffer: Very interesting. When you say that in the client/consultant model the clients have the money to do the work, what is 'the work'?

Graeme Hussey: It depends on the client. I could send you a document which lists all the services that we provide to clients.

Graeme Hussey: $\quad$ For example, Convivium came to us and asked us to do a specific work. If you started, "We're looking to buy something from Regional, can you come help us with negotiating that deal". That's a very defined piece of work.

When that didn't work out, you came to us and said, "We're interested in a similar approach with another developer, can you help us do an expression of interest (EOI) to see if there are other developers out there who might have something like that to offer". A couple proposals came back, but they didn't meet Convivium's criteria.

My recent understanding is that we have a small contract with Convivium to consult on feasibility. The premise being, "The two first approaches didn't work; we're thinking about going out on our own and we would need a development consultant, can you at least help us with some initial aspects of that". I don't think there's been much work done, but I think it's moving in that direction. But just for specific tasks - almost like "what to do - the next thing".

Sometimes a potential client comes to us and says, "We want to do a project, we're interested in hiring you, or somebody else, as a development consultant. or an owner's rep, or a project manager", whatever terms they want to put there, "Could you help us understand what the scope of services you provide are and what the costs of those associated scopes of services are”. 
Lynn Pfeffer: Yes, that's a very different question.

Graeme Hussey: That is a different question. There are almost three lenses that a potential client comes to us with, so that's one lens.

Generally, there are three baskets of clients; there are three typical questions clients come to us with - in that first meeting, when there's no contract yet. One is, "We're thinking of doing a project, we're looking for somebody to be our owner's rep, developing it all and project manager", whatever it is, "Can you tell us the services you provide and how much that might cost", and that might not be a hard number, it might be a percentage of cost or something like that.

The other lens (second lens) that they come to us from, is like, "We're thinking of doing a project, we're not sure if it's feasible, can we hire you to help us understand if it's feasible".

Lynn Pfeffer: Like a feasibility study?

Graeme Hussey: $\quad$ The study and the scope of that might be slightly different depending on the client and the characteristics of what they have, or don't have, like do they have a site or not, do they have a defined business model, or not. Sometimes we need to get an architect to help us, or a planner; we might hire them as sub-consultants. We might give them a fee of "this is the total it's going to cost you, and in that includes the fees of the architects and the planners".

The third lens is that they come with a specific question, and usually those are the groups that are going to spend some money, and then they're going to realize, "Oh, we need to come back with one of these other two lenses" and it's usually - they want to know what the services are that you provide, and what are those things. To be honest, I bet most cohousing groups right here-start with this lens.

Graeme Hussey: $\quad$ Most of our clients do all these surveys and come to us with, "we want green sustainable housing, we want four floors and we want 50\% to be one bedrooms and two bedrooms, and we want this specific amenity space" - versus they don't even know the business model, which is almost like a one-page pictogram of how things fit together. We think of every project as needing three general, broad characteristics. Most groups jump right into some details that fit into some of these three broad 
characteristics without knowing broadly what those three things are; not really looking at the big picture; without the basis of having a viable business model.

Lynn Pfeffer: This is such an important understanding. You were beginning to say that every project needs three general, broad aspects.

Graeme Hussey: $\quad$ Land, money and capacity. If you don't have land that works for your needs, if you don't have the money, and if you don't have the corporate capacity you can't do a project, and within each of those there is more granular details of, "you need to have these things - and it's not like you have to hit one, you have to check each of those - to have a feasible project; and within those there might be many, and you have to check every one of those.

Graeme Hussey: So, an example of this is the Deschatelets project; that's a good modern example, because Clarence Gate is done. We analyze "what will make this project feasible?". And to answer that question it's: "What will make the land feasible? What will make the money feasible? And what will make the capacity feasible?" That's a whole bunch of checks - and we're trying to check all those boxes, and until we check all those boxes there's not a feasible project.

And in my mind, there's no point in diving into the rabbit holes until you can broadly answer those questions - check those boxes. There's no point in developing partnerships and getting people's expectations up when you don't even know where the money is. There's no point in diving into what's the perfect piece of land unless....

Lynn Pfeffer: If a cohousing group wanted to start a conversation like the one you're having with me, where I'm consulting with you, and you are saying, "This is what you need to be doing", what would you say to them?

Graeme Hussey: I would give them similar advice before they've hired us, because it incentivizes them, they then think, "Oh we can trust them, they're giving us good advice, and it sounds like good ideas."

Lynn Pfeffer: It definitely gives a good impression: "these people are experts, they know what they're doing." The people interested in cohousing are usually intelligent people, but they're not real-estate developers; they don't know the territory, they don't know the landscape. They're motivated to learn, and they are doing their best to get the information, but the information they need is not easy to come by. 
Graeme Hussey: We have a presentation workshop that we deliver for clients when we're in that feasibility phase, which is 'Real Estate 101' and it's running through this information in a presentation environment. One of our clients is the Anglican Diocese of Ottawa; they have a couple of interrelated charities, like Cornerstone Housing. We're currently working on four projects with them, so we're giving that presentation to them and their partner organizations.

Lynn Pfeffer: Where would put what Ronaye Matthew is doing, which is giving a complete consulting service, but related to cohousing development; which is that model?

Graeme Hussey: That's the development consultant working for the not-for-profit client. We have not-for-profits, we have charities, we have co-ops, all who are our clients (that's the corporate ownership structure, or sometimes we call it the governance structure) and we can consult all of them. We don't have experience specifically in cohousing governance structure, but we have experience working with not-for-profits, charities and co-ops, all who work with volunteers, committees, boards, and all have group processes.

That's our bailiwick. Cohousing is just the bylaws and there's - I'm not trying to smooth over what cohousing is and discredit it in any way - but just to say that I think it's not dissimilar to many of our other clients. Also, even on what I call the 'value side', around whether it's the building design, or the use of amenity spaces and creating community, or environmental design, you see that in these projects anyway, that's not different to us either.

Lynn Pfeffer: I have the feeling that out of all the alternatives that a cohousing group has in Ottawa - and there were several groups that have been trying to get going and have not been able to - Cahdco has a lot to offer.

Graeme Hussey: A church in the west end is coming to us now because the church is looking to redevelop their site. They were looking for partners; a local architect created a concept and then tried to find the owner to meet the concept. Rather than creating the cohousing group first and then going out and looking for land, she found the land opportunity and was looking for the cohousing group. It would be a perfect match for a cohousing group, if they thought that was the right site, because that's what a cohousing group doesn't usually have - the site, right? 
Another comment is, if a cohousing group goes out and selects a design-development partner, they still need a development consultant/owner's representative, or the project won't go. The biggest challenge for a cohousing group is on the financial side, and how to pay for the project, in that complicated nature.

Lynn Pfeffer: It seems that most potential cohousing residents don't seem to be that concerned about that; most members seem to think, "I know right now that I could sell my home and have enough capital, or equity to pay for a market rate condo, so why would I not be able to invest and pay for a unit in a cohousing project". Is that naïve?

Graeme Hussey: That's not naïve, but that won't get you to how to finance the project, which is not in the end game about who's paying for it, it's the cash flow of it.*

If I'm a condo developer and I've got a 20-unit condo building and a cohousing group comes along, and they want to buy it - and each unit costs $\$ 300,000$ - are they willing to put the $\$ 300,000$ in on day one, before I put a shovel in the ground, all cash.

Because, usually what happens with a condo is you put something like 5\% down and that goes in a trust fund, and the developer can't access that until about two years after the condo is built and it's been registered, then all their sales money comes out of that. In between from when they pre-sell to that two-year point of when it's registered, *they finance the whole thing with investors, and that's why they need to make enough of a profit; is because that's what costs so much money.

In the end, the members have the money that comes at that point because you'll probably have to be structured like a condo. If you put your money in at the beginning, it increases your risks; and you know the question is, "are people going to be willing to do that?" There is probably a three to four-year time difference between when you have to say yes, I commit, to when you move in.

If somebody owns a home, and it's worth $\$ 500,000$ and they have no mortgage on it, and they could sell that and buy a $\$ 300,000$ one-bedroomed condo, are they willing to re-finance $\$ 300,000$ of that and somehow is this even possible, is the question. Those are the complicated parts, it's the cash flow, not whether can these people afford to buy it.

Lynn Pfeffer: Looking at the difference between the kind of cash flow a group would need if they were wanting to buy a building before a shovel goes into the ground, versus buying 
in to a turnkey condo building; you are saying the cash flow is all at the end for the turnkey option, whereas with using the developer model, more investment is needed in the beginning of the project.

Moving on from this particular discussion regarding the complications centered around cash flow and timelines. Ronaye Matthew has offered to do a cohousing development training here in Ottawa; would you be willing...

Graeme Hussey: $\quad$ If your question is would one of our staff, or some of our staff, do that training; absolutely!

I probably would not commit to doing that unless we had a cohousing client that, you know, was going to commit to something. With small specific contracts where we're not sure if a project is going to go forward or not - maybe, maybe not. But if there was more of a commitment and we felt that the project was leading towards (something tangible) then absolutely.

Just so you know, that's something we have invested in during the last few years where it's all new staff; besides Dennis and another person who are more experienced. There's a lot of investment in professional development.

Lynn Pfeffer: I would love to see that happen because as far as I'm concerned cohousing has a future, especially in terms of senior cohousing. It is an amazing way to go for a group of older adults. It makes sense from many different perspectives and the biggest is in terms of creating a community structure different from what we have now. We're isolated, people are growing old alone - especially older women are growing old alone - and the idea that older adults could be in a community where they're sharing their living day to day, where they're thriving because they're interacting is important.

There are always challenges in groups, but I believe that the whole consciousness of a group evolves to a higher level when you live as a group. I mean there are so many aspects in which I think cohousing makes so much sense; it's not for everybody, but it would be a way to deal with the fact that there's a huge aging population and what's going to be happening to seniors in terms of housing.

Another thing that I point to in my research - I'd like your opinion on this too -is that it sounds like the different levels of government have looked at affordable housing. Affordable in the context of the criteria set by CMHC. According to statistics only 10\% 
of households in Canada are eligible for affordable housing; that leaves $90 \%$ of the population relying on market housing. I'm not saying that the government shouldn't be supporting the poorest, but there are also many other housing needs, alongside social housing.

Graeme Hussey: I think the statistic in Ottawa is that 6\% of Ottawa homes are affordable housing; there are 400,000 homes and 6\% of those are affordable housing, owned by CCOC and OCH. The actual need for affordable housing would be $20 \%$, or more. There are about 400,000 homes in Ottawa, and about 22,500 of them are affordable housing units.

Lynn Pfeffer: When you say 'homes' do you mean single-family homes and apartments?

Graeme Hussey: $\quad$ All of those. These are the physical units, and there are two and half people that live on average in them, and that creates the one million population. If you do 22,500 and divide by 400,000, that's roughly 5.6\%, and these were estimated numbers. That's your 6\% right there. The need is likely around 25\%. That's why governments aren't funding cohousing, co-ops, not-for-profit, or market. I think you're confusing affordability level with ownership structure.

Cohousing is an ownership structure, it's not an indication of affordability. The government has put emphasis on providing housing that's affordable to those who have the least means; they have not chosen any emphasis on what the ownership structure is.

The 'Action Ottawa' plan doesn't say it has to be 'not-for-profits', it doesn't say it has to be 'co-ops', it doesn't say it has to be 'co-living,' or 'cohousing'. I mean, it doesn't say it has to be private market, it can be any of those ownership structures. What it says is we're looking for housing that meets this definition of affordability and this definition of a kind of a target demographic, and they group those into seniors, supportive housing and mixed housing.

In say, the seniors' category, they're not saying what the kind of ownership structure has to be, but they are saying it has to be rental; one could have cohousing rental theoretically just as one could have cohousing ownership. You have private market rental, like Regional Group owns rental properties, and Regional Group also sells homes - ownership. And it's the same thing with CCOC as a not-for-profit, we have rental housing, and we can develop an ownership condo and sell it. 
Everybody - all those different ownership structures - they can sell units, or they can rent units. What I'm saying is the government is focussed on rental units that are affordable to those who are the poorest; how a cohousing group can reflect on this is that most of the people who are interested in cohousing aren't poor enough to meet the criteria of what the government is looking for.

It's not that they've de-prioritized cohousing, or co-ops, or not-for-profit, they haven't prioritized any of them, they've just said we're prioritizing the poorest people and most members of cohousing are not the poorest.

Lynn Pfeffer: I would speculate that at least a third of people who show interest in wanting to live in cohousing are of low to moderate income and cannot afford to buy a unit.

Graeme Hussey: $\quad$ That's because cohousing tends to look at an ownership structure, because it would be difficult to finance the rental structure - again, the cash flow of the rental structure. And selling a unit doesn't fit into where the priority is around affordable rental housing.

Lynn Pfeffer: What if a cohousing group wanted to have a combination of rental and ownership so that they could accommodate people who could not afford to buy, and who wanted to rent. Is there any mechanism whereby a group could do that - could have both ownership and rental.

Graeme Hussey: Well, you can have mixed tenure, and you have that in every condo building.

Lynn Pfeffer: But without any kind of subsidies from the government for those people who couldn't afford it on their own?

Graeme Hussey: $\quad$ That's right because what you're talking about is every typical condo building is mixed tenure, some people who live in one condo unit own it and live there, and their neighbour might be renting out their unit. But it's all been financed through the ownership structure, right, so you're still talking about ownership and not rental even though some people at the end are renting.

Lynn Pfeffer: Are there any subsidies for those people - let's say they're affordable units people who are on the low-income scale, or as you call it the low to moderate income scale, who would want to rent a unit, is there any mechanism that helps finance the 
building of that unit for the group? That would make sense to me. Why not increase the number of affordable units in the city by helping people who are developing projects include some in their projects?

Graeme Hussey: Well the government is doing that, it's just focused on the lowest income. What I'm circling at here is that *the cohousing ownership structure doesn't map on well to the government criteria, and to be honest I don't see that changing.

What you're talking about is having a few units in a building that would be affordable, and right now if you're a private landlord and you had a unit in a building that was vacant and you wanted to have a tenant in there who was off the waiting list, you could go to the city housing branch and say, "I've got an empty unit, I'm willing to take a tenant off the waiting list, what is the rent that they would be able to pay" and you could accept them.

But that landlord had to take the developer risk to develop that unit, they had to pay for the construction of the unit and what you're asking is, will the government pay for the construction of the unit if the cohousing group promise it to be for somebody who fits affordability criteria.

That's what the Action Ottawa program does, but they don't do it in the fragmented way that you're proposing, because they have such limited government funding they're putting it into the way that they think gets 'the biggest bang for their buck'. And so, putting in six units in one project and six units in another project isn't as cost effective for them as just paying for a 20-unit project.

Lynn Pfeffer: Okay, that makes sense. What about in the case of a group of private individuals trying to finance a cohousing project, and realizing they won't be able to include affordable units without financial support from the government; are there other kinds of support that would help a group, if it's not financial support?

Graeme Hussey: $\quad$ Well I think it comes back to what we were talking about, getting good advice.

Lynn Pfeffer: Do you know if there is any policy planning taking place in terms of senior housing for the future, that isn't about affordable housing, given the number of seniors that are going to be on fixed incomes, but may not fall into the lowest-income 
categories? For instance, in the National Housing Strategy? Did Cahdco get a chance to have input, did you want to have input, did you give input?

Graeme Hussey: We did, yes. It's been quite a while to be honest, like most of the engagement around the strategy was last year. I'm sure there's lots of work being done from a planning policy perspective around that, whether it's the National Housing Strategy, or provincially. I guess that kind of broadly answers your question. I'm not involved in a lot of that.

Occasionally government consults with stakeholders and we're one of those stakeholders that get consulted around the National Housing Strategy and some of the other initiatives that have led to programs being created in the last year around CMHC. For example, last year the province created a new long-term affordable housing strategy and CCOC and Cahdco were one of the stakeholders consulted. But I'm not really working on policy planning.

I think there is a lot of planning going on. The one thing to be clear about is the numbers don't pan out. If you look at the numbers and ask what are the demographics that are most in need in terms of supply and demand of affordable housing for the lowest-income people, it's not seniors.

From a demographic perspective they are the least in need; it's typically single mothers and single individuals who have been in shelters for a long time, it's more that demographic. The numbers don't point to seniors and so that's actually why the housing branch - they have the three baskets of priorities: supportive housing, mixed housing and seniors. The one of these baskets where they dedicate the least amount of money, and the least number of RFPs, is seniors. They only do it because the province asks them to.

My understanding is, that if the city could decide, they wouldn't put any money into seniors, because just from a demand versus supply and need analysis - not to say there's not a need for seniors - but there is a greater proportional need for those other things than seniors. There's 10,000 people on the waiting list right now, and on the waiting list for seniors it's like 300 people. 
So, of that 10,000, it's my understanding that less than 5\% is seniors. ${ }^{122}$ When the other 95\% or more, is not seniors, you obviously understand why the city would put the priority on that.

Lynn Pfeffer: I wish it was a broader picture that people were looking at; it seems to be just about housing as a shelter.

And I don't mean shelters, like 'women's shelters', but I mean 'housing as shelter'. My concern is around 'the quality of life' of older adults; for example, the single person who is aging alone, and how much healthier and happier they might be in a cooperative community.

Graeme Hussey: $\quad$ I'm not doubting that, I'm just saying my simple analysis is more about the affordability of it, like who has the lowest incomes. The need is great overall, for everybody, that with the limited money the government is choosing to put their money in certain places.

Politically though I think there's a disproportional amount of political support for seniors versus what the money needs are. My understanding is the housing branch would rather not release RFPs for seniors housing, explicitly for seniors, but the province makes them do that because politically the province knows that's where all the votes are, because seniors vote.

There's significant political support for seniors, but if you're talking about building affordable housing for those who have the lowest income it doesn't pan out as the biggest need. I'm not the person who decides where to spend the money, it's just my understanding of how some of the government's view it.

Lynn Pfeffer: What I feel badly about is seeing all of these older people in senior residences whose lifelong savings are going into paying exorbitant rents.

I mean there are basically two alternatives when you can't live in your home any longer - either you qualify for an affordable long-term care residence, or you end up having to go into a private senior residence. There are lots of people that are falling through the cracks - they aren't poor enough to qualify for seniors affordable housing but can't really afford the private residence. They also won't have any inheritance left to give

\footnotetext{
${ }^{122}$ Saide Sayah of the Affordable Housing Branch of the City of Ottawa, states that $20 \%$ of the wait list are seniors; this translate to 2000 seniors out of 10,000 people on the wait list, not 300.
} 
their kids because they're spending it all on the rents for the old-age home. Who do you know who wants to live in those places?

From my perspective, the idea of creating projects that give an alternative to people who don't want to end up in those private residences is a worthwhile endeavour.

Graeme Hussey: $\quad$ And the government - in affordable housing the focus is on people who don't even have that choice, they can't even choose the private residence, even the $\$ 2,000$ a month one.

Lynn Pfeffer: I hear you, and I have absolutely no argument with the fact we have to, as a society, find ways to support them; that is my philosophy, no doubt. And once we've done that, can we look at some of these other areas that are really serious in terms of how we live you know as a culture, as a society?

Graeme Hussey: $\quad$ With all the money that the government is putting into what I'll broadly call, 'affordable housing', there will be more opportunities that aren't purely dedicated to those who need the most, like the poorest people; I think there's going to be opportunities for many things, but so far, they're focussed exclusively around rental.

There have been some initiatives announced for just market rental development, to spur more rental development; what's interesting from a policy perspective is the government is trying to limit how many people are in ownership and promote rental. From a cohousing project perspective - which is not on the rental side, but on the ownership side, and not on the affordability side - you don't even hit that other basket.

They're actually trying to dissuade people from buying property at this point because they feel like Canadians are over-extended, and you see this in the change in the mortgage rules. From a policy perspective there probably isn't a lot of support for, how do we create a market ownership development for seniors.

Lynn Pfeffer: They may be thinking, "well if they (cohousing group) can afford to do that, let them go do it."

Graeme Hussey: $\quad$ Absolutely, and if they can't organize themselves to do it, then they can afford other alternatives. It might not be the ideal in terms of the social community values, but any cohousing member - if they can afford to sell their home and buy a unit in a cohousing project - they can afford to buy a unit elsewhere; it doesn't have to be in 
a cohousing project. They're choosing to do that, they could live at Greystone or they could live in Minto, or anywhere else.

Lynn Pfeffer: But the main reason that they're trying to do this is because they really feel there's a lot of value to the idea of a human being living in community and not, you know, as a private isolated individual.

Graeme Hussey: $\quad$ And so, in my thinking about that, I don't know if there'll ever be any government policies that really support that. 
Interview with Mr. Jamey Burr

Former: Program Manager Canada Mortgage and Housing Corporation (CMHC)

Current: Upper Marlowe Consultants

October 31, 2017 (length 2:08:50)

Jamey Burr: I've spoken with other people who are doing academic analyses of different housing types, as well as advocates for a particular typology; it's not uncommon that their analysis is focused on describing and making the case for the housing typethat it's a good thing. Then they expect the analysis should be so compelling that everyone will agree and that resources will magically appear. The theme of their approach is, "this is a good thing, we need more of it and somebody should do something about it".

It's the third part - "somebody should do something about it" - that's difficult. We have many wonderful models in Canada, but how we can make them happen, and who needs to do what is the question. Governments have become good at saying, "we provide money but it's not our job to foster these new things; we're busy enough just cutting cheques and so forth".

That question of who should be out there fostering new ideas is a difficult one.

I would say academia is in a very different head space about what is necessary; for years you had people preaching that it was all about inefficient design and that if we designed our houses differently the world would be a better place. Again, saying, “and it's now someone else's job to do it” - the Avi Friedman (1990) flexible house approach. Then they wonder why it doesn't happen.

Co-housing is a wonderful example of something that combines creative influence from the conceivers, is giving consideration to the long-term and is looking at real societal issues. *The questions are around capacity and how can we realize this.

Lynn Pfeffer: What have your roles been over the years?

Jamey Burr: For a number of years I managed funding programs at Canada Mortgage and Housing Corporation (CMHC) whereby the federal government provided funds to community-based organizations to create non-profit and co-op housing.

That all changed with the Mulroney government when they cancelled new commitments in that program because of concern about deficit. The funding model 
was that when a group gained a funding commitment year one, they gained access to funding for 35 years.

Non-profit organizations, with CMHC's backing, would take out a loan for 100 percent of the cost of the project. They would collect rents from their tenants, but they would also receive a monthly subsidy cheque from the government to help to defray the cost, with the agreement that they would have a certain number of lowincome people there who would benefit from reduced rents. That was all built into the funding structure and that agreement was cast in stone for a 35-year period. That started in $\mathbf{1 9 7 8 .}$

Lynn Pfeffer: And when did the 35-year commitment end?

Jamey Burr: It was unique for every project. If you were part of the 1978 commitment stream and your project was built over two years and you took occupancy in 1980 your subsidy would run until 2015.

Let's go back to the 1930s. Affordable housing began in Canada as a public health initiative. The concern was that slum housing was a breeding ground for disease. Impoverished areas would then be epicentres of viruses that would travel into the population. We didn't understand at that point how diseases were communicated. There was a combination of care for the people, but also a concern for infecting everyone else.

The dilapidated housing was removed. New projects were built. Then the Second World War was upon us. At the end of the war there was a huge need to increase housing. At that point housing production in Canada was unsophisticated. You only had a few large integrated companies. You did not have a system of project finance. There was a great lack of serviced land. Governments stepped in to do all of that. Canada Mortgage and Housing was created to acquire land and put in the services. It was also charged to set up a system of finance whereby homeowners could borrow. At first, they borrowed directly from the Government of Canada; until our lending institutions got sufficiently large that they could also offer loans. Subsidies were provided for low-income families and for returning veterans.

\section{Lynn Pfeffer: Most of which the government no longer does, right?}

Jamey Burr: Correct. That meant hiring scores of architects and planners and project managers at the federal level, many of whom came from post-war Great Britain. 
They came with notions of the garden city - Ebenezer Howard - that poor people's conditions could be made better if you put them in attractive housing in a leafy setting.

Our first major public housing project was in a relatively inter-city location Regent Park in Toronto. They had a large tract of land; they closed off some of the side streets to create this uniform high-density housing (super block) surrounded by green space.

Looked great on the sketch. From day one there were issues because when you took away the street you took the development out of the context of the neighbourhood and you created an island where bad things could happen. The criminal element quickly found that this was a great place to hide from police. They operated drugs and prostitution in that area.

Quickly the residents of the project were stigmatized. They were probably involved in those activities, but they didn't originate them. The criminal element took control of that area. The reputation of this government-run, government-designed housing was under attack.

In the 1970s people came forward to say affordable housing should be community based. Local groups should be empowered to design their housing, own it and manage it.

Lynn Pfeffer: When you say "local groups" did that tend to be primarily church groups?

Jamey Burr: Many of them were. But there was a strong effort to make this as broad as possible. A great deal of money was spent to build capacity for whatever group wanted it. As a funding officer one of our roles was to promote and find organizations and give them the moral support and the technical and training support so that they could be active participants in the program. This was done on an experimental basis in the early '70s and was *formalized in an actual broad program in 1978. People sometimes refer to it as the Section 56.1 program, the technical section of the National Housing Act that allowed it to happen. A great deal of effort was given to diversifying the type and choice of housing away from the monolithic government-owned projects.

Lynn Pfeffer: When this was cancelled in 1986 was it primarily due to the lack of funds? What were the reasons? It sounds like a good program. 
Jamey Burr: It was political philosophy. This happened during a Liberal tenure (Pierre Trudeau). Then we suffered through the recession of the early '80s, and the government was replaced by the Mulroney government who said we're going to set our fiscal house in order.

The Section 56.1 program was deliberately set up to mix incomes. A portion of the subsidy was for poor people and another for moderate income, $\underline{\text { but the project }}$ was open to anyone to wanted to live there. There was a perception that the higherincome people were subsidized by the taxpayer. That's not true. That perception and accusation was powerful; calling the program wasteful was an an easy target.

Proponents of the program did a poor job of defending it. They could've come out with a fact-based argument, "no, here is our subsidy, it's going to this tranche and to this tranche." They came out with these vague but honest statements, "we're building community, we're sustaining community". I was working in the bureaucracy as these waves of attacks were coming against the projects, and people were trying to defend them, and we're charged as bureaucrats to find some acceptable middle ground to explain what's going on.

The Mulroney government ultimately decided it could not support any housing that was not targeted to the lowest income population. He commissioned a task force in 1986 to study and report back.

The other dynamic was the constitutional crisis, wanting to repatriate the constitution - but we had provincial and territorial governments screaming that they had inadequate powers and wanted changes. Housing got tossed in to that whole area. Appeasing these governments became more important to the federal government, than addressing the issues of poverty and inadequacy.

Lynn Pfeffer: I've had a hard time understanding why the government's focus seems to be only on affordable housing, as defined by the "co-ordinated income threshold"

I don't think of housing as only a roof over one's head that protects from the elements and keeps one safe. I think of it as something that's part of the fabric of the city and the society; it needs to operate as more than just a roof over our head. The position of, "we'll only address the low-income group" seems to limit the issue; there are different kinds of housing needs and they may not be for shelter, but they may be for community, or for health needs.

Jamey Burr: There's a big difference between how a project is conceived and operated and who pays for it. That's where we get into further discussions of co-housing. 
When the Mulroney government announced that they would have this strictly targeted program they also said that it will not be solely funded by the Government of Canada. Provincial governments will manage the program - they will decide which community groups get the funding, but they have to provide at least 25 percent of the cost.

The federal government was providing 75 cents on the dollar; the province 25 cents. But the provincial government decided who would get the funds. There's an unfortunate history of political manipulation and patronage, but we (CMHC) tried to have objective selection criteria so that when politicians challenged us we could say, this is why this group got it, and not that group. One wise boss said to me, "we try to protect $90 \%$ of the allocation, and if the politicians target in to the other $10 \%$ that's the cost of living".

Provincial governments could do as they wished. If they wanted to have a political process for selecting the groups, as they did in New Brunswick, Nova Scotia and Newfoundland, there was nothing we could do about it. They had an allocation process; the bureaucrats would come in with a list, and the premier and the cabinet would select the projects.

Lynn Pfeffer: Were there any provinces where that process was more objective?

Jamey Burr: The groups in British Columbia have always been the most capable, of galvanizing political support. If you began messing with the application process they had the ability to stand up and challenge it.

Lynn Pfeffer: Why do you think B.C. groups are more capable?

Jamey Burr: That's a good question. Politicians at all levels of government in B.C. support affordable housing because their constituents tell them that they should. If you get voted in, even if you are of conservative cloth, you can say positive things about affordable housing knowing that you're not risking your political life. So, why is that? I don't have the answer as to why they are more accepting than others. Even the most conservative of governments in B.C. never wavered from continued support.

Let me take the time-line a little further along. We have this period where the Mulroney government said we will contribute funding with the provision that the federal funds go to poor people and that the provinces have to contribute a portion of the cost. That lasted from '86 to '92. We're under severe deficit siege and had gone 
through a recession. In 1992 the government said, "that's it, no more new funding for new projects. Stop!" The only country in the developed world that stopped funding new commitments.

The housing movement was stuck back in 1986. They thought the challenge was getting the government to go back to Section 56.1, which they dearly loved. It gave them huge resources. It gave them choice. It gave them flexibility. There are many wonderful projects that came out of the program, with good structures and more appropriate for the people living in them. Contrast that to the public housing monsters that were built in the late 1940's.

We got a change in '86 and then a change in '92. Housing advocates are still sitting at the start line talking about how we should go back to the way it was in '78. Governments said, "You're not living in the same reality. We can't have a dialogue. We don't care what you think". From 1992 until 2000 there was sporadic federal government support for housing.

In 1986, when the government said federal money will only go to the low income population, some provincial governments said, "We disagree; we understand the federal perspective and we know your stipulation, but we're going to use provincial monies over and above the 25 percent that we're required to put in, and that will allow income mixing". British Columbia, Quebec and Ontario did that.

I can't even keep track of it as a historian of social housing; the project designs got more and more complicated, the project funding got more and more complicated. But you had demonstration from three provincial governments that they thought that income mixing was an important thing.

When it came to the cancellation of programs, B.C. and Quebec said, "we're going to continue with limited funding programs, solely funded by the provincial government".

Lynn Pfeffer: In the period between 1992 and 2000? For funding mixed income programs?

Jamey Burr: Yes. Again, they knew they had strong support from their voters. In Montreal, especially, there's huge support for affordable housing, in every neighbourhood and through all elected officials. There is an extremely strong lobbying voice too.

When our fiscal framework got in a better shape after years of deficit reduction, and the economy improved, the Government of Canada said, in the early 
21st century, "all right, we're coming back in to the world of affordable housing; however, it's going to be different. We're not going to provide that layer of subsidies that goes on for 35 years. We're going to provide a cash grant up front." This formula continues to this date. There is an expectation that a certain percentage of people are of low income, and you are encouraged to find other funding sources to make your project a reality, and projects will be selected on the basis of their financial viability.

*We went from a 1978 program that said we want as many diverse groups as possible, we'll give you money to support your development and your initial work, and we'll be there for you for 35 years of funding, to one that says, it's now a track meet, there's money available, but it's deliberately not enough to pay for your project; you're going to have to find other funding sources and may the best group win. From the perspective of a community organization trying to play in this game it is very, very different.

Lynn Pfeffer: Who were the groups that would win out?

Jamey Burr: Those that were able to sustain a presence throughout the bad years; in Ottawa you had two players, CCOC. and Ottawa Community Housing (OCH). Ottawa Community Housing had changed structure many times as we went through provincial/municipal amalgamation changes. In the old region of Ottawa, the City of Ottawa had its non-profit arm, Nepean had one, Cumberland had one. Kanata had nothing.

When the new big 'City of Ottawa' was created, City Living morphed in to Ottawa Community Housing. At this time, the provincial government also said, "all of the provincial projects that were developed, all these years - we're transferring ownership to Ottawa Community Housing. You have no choice, you must take these over". All the monolithic public housing projects that had been built by the province, we'll continue funding it in the way that we had before, but you are now the owner and the manager. There was no end of headaches; can you imagine suddenly waking up and being told this is now yours, and good luck?

That being said, $\mathrm{OCH}$ is an organization that has capacity; they have many employees, they have a substantial balance sheet, they have capacity to undertake new development.

Lynn Pfeffer: Has it become a monopoly then? 
Jamey Burr: No, because there are two players. CCOC is the other. But it's them and everybody else. CCOC actually spun out its development arm, Cahdco, to be able to provide consulting services to the other non-profits, and it has worked fairly well. Multifaith Housing Initiative for example uses them. Cornerstone housing for women uses them. *When you look at the winners of the proposal calls by the City of Ottawa for the last several years it's almost exclusively Ottawa Community Housing, CCOC, or a group that CCOC is working with through Cahdco.

Lynn Pfeffer: In regard to Cahdco, how would a Cohousing Co-operative fit in their mandate of offering non-profit development consulting?

Jamey Burr: It would. If a group went to them and said, "we have an ambition to win a proposal call through the City of Ottawa; what do we do?" Cahdco would say, give us a cheque for $\$ 30,000$ and we will start work. We will have to jointly find a site, and hire an architect, and develop plans, a complete operating plan and budget, and then submit that to the city. If you lose your $\$ 30,000$ is money that is gone.

Cahdco has to make a wise business decision as to which groups they'll work with, because they only have so much time, and they want to hook themselves up with a group with a high chance of success.

Let's look at things broadly going back to 1978, because it's relevant. Governments invested heavily in building a consulting network that could service the community-based organizations that Section 56.1 program was intended for. Whole careers were made in providing that sort of service. Every community had a few organizations. You could choose which consulting firm you wanted to work with. People who were involved were comfortable that there would be sufficient level of business in a given year that they could make a living from it. That was the case from 1978 to 1992. An aspiring group could interview the various development consultants in town and say, "here's what we want to do, will you take us on?"

There were things that would make your group likely to advance. If you owned land; if you were a church group that had land - that's a huge thing - and if you had benefactors who were willing to donate money to you. Every effort was made to match groups up with the professional capacity to do the job.

Consulting firms chose to work with skeleton groups because they felt that a large group of community volunteers did not add value to their effort in the early machinations - it just actually slowed things down. They would form a temporary 
board of directors of $X$ non-profit, maybe four people; they would use that as the basis to get a government allocation and when they were successful, and government said, "yes, we'll award you money", they then said to X non-profit, "okay, it's time to broaden your membership". Hopefully those groups were rooted in some community base so that they had ready access to a membership. But it wasn't this notion of a large volunteer group leading up to something; it was quite the opposite. It was the professionals who were running the system, and when they were successful they encouraged the non-profit groups to expand. Contrast this with a cohousing group.

Lynn Pfeffer: The consultants would work with a small number of representatives from a non-profit and then go back and create greater capacity in the group?

Jamey Burr: Cohousing groups are having a hard time finding people who can provide them with the professional expertise to understand the challenges, make choices, and take appropriate action.

\section{Lynn Pfeffer: Why? What happened?}

Jamey Burr: The Ontario N.D.P. government under Bob Rae is in power from 1990 to 1995. When the federal government under Mulroney announced it was cancelling all new commitments, the Rae government said, "Well, we're going to step in with major investments in affordable housing at the provincial level and carry on with support on our own".

This was at a time when the Toronto real estate market collapsed. There was an over-build of condos. There was a glut of housing on the market. Prices tanked. Interest rates were still very high.

Owners of condos were renting them out for whatever price they could obtain, which was often very low. A new luxury condo unit could be renting at a price that was lower than what the non-profit housing advocates could deliver.

The Auditor General of Ontario looked at this equation and said, "this is crazy, why is the government of Ontario investing money to create stock when we have surplus of stock." Again, the non-profit housing groups failed to come up with a convincing argument. Basically, they said, non-profit housing is a legacy that will endure for decades. Yes, that's true, but in a province where people were being laid off, teachers were being forced to take unpaid days, human beings were making sacrifices, it wasn't a convincing argument. 
The non-profit housing movement in Ontario was terribly stained by this. Mike Harris had an easy time of coming in and portraying the N.D.P. as fiscally incompetent.

The day Mike Harris was invested as premier he cut off the provincial funding. But he took an extra, legal step. When a commitment is made to a group that says you have a funding commitment from the government it's a legal document, it's binding. Harris said, "no, those documents are null and void".

The groups had to individually go to court and have a judge say, "no, this is a legal contract and the government has to pay". Housing consultants collectively said, "we have to find new work. We are going to abandon this sector and work somewhere else because we have no guarantee of continued cash flow, we just can't make a living". They evaporated.

CCOC was able to continue because it had a sufficiently large portfolio and so much cash flow that they could say, "You know what, we're always going to keep one or two staff around who have these skills". Ottawa Community Living, was also sufficiently large that it could allocate resources for that.

In Ontario, from 1995 until the federal government of 2001, there was no funding support for new housing. Goodbye to all that consulting capacity. Some of them moved to British Columbia; some found new careers. When we say that certain groups have a monopoly in town it's because everybody else left.

Look at this legacy - in the '70s governments investing heavily to create capacity; 20 years later, governments purposely destroying capacity. We could moan and say past mistakes have put us in this terrible situation. The bigger question becomes, what are you going to do about it? What's the reality and how can we move forward?

Developing housing is difficult. That being said, many community organizations demonstrated over the years that when they work together effectively they can make it happen.

Lynn Pfeffer: Which community organizations? Mostly, it seems that church organizations have had both, the money and the land.

Jamey Burr: Yes. Usually they have an organizing base and can rely on a formal structure to get them started; there are known relationships, there's a gathering of people that have skills in many of the necessary areas, and a credibility to go out and recruit other people. 
Lynn Pfeffer: What about community organizations other than church-led?

Jamey Burr: It has been done by people involved with health-related issues: parents of children with cerebral palsy, or developmental disabilities.

Lynn Pfeffer: How do we transpose that in to a project for seniors? Co-housing in general, but also co-housing for older adults or seniors?

Jamey Burr: **Now we have to peel away the ambitions within co-housing. What is it you're really trying to do? Are you trying to create an affordable environment for low-income people? Are you trying to extend the sorts of health care, home care services available to a person so they don't have to go to long-term care, or retirement residence? Is it an income issue? Is it a health issue? Is it a desire to create a utopian environment that isolates you from the evils of society, because that's what I've seen in many groups who've chosen to use the co-housing terminology?

Lynn Pfeffer: Personally, I don't see my own ambitions as utopian in the sense of an isolation from the rest of the world. I see it more as a desire to become a part of a community within the larger community, to interact with one another.

Jamey Burr: That's been the least understood aspect of co-housing. Back to one of your first questions, why is it so poorly understood and so infrequently used? I don't know, is the short answer.

We have to start from the understanding that most Canadians are well-housed. There's not a sense of urgency about anything in the Canadian housing system. That may be wishful thinking, or people choosing to ignore the circumstances of some? But, generally, Canadians feel that the housing continuum is adequate. There's also a strong belief in Canada that housing is an effective investment vehicle. Protecting one's investment is paramount.

In my experience, seniors are hesitant to embrace an idea unless they can actually see it built and go kick the tires and be confident of what it is. Their willingness to experiment is low. Their trust is correspondingly low.

I've worked closely over the last couple of years with a church group that is planning a seniors' non-profit project. It is going to be a good project because they 
are motivated. It's on Alta Vista. They operate a 30-unit project that is subsidized by government. They are aware that many of their residents have been there for a long time. One of the surprises for people who operate non-profit housing for seniors is how long seniors are living.

When they conceived the project in 1980, "old" was 65. Now, those 65-yearolds are still there and they're 90 and their needs have changed considerably. The buildings were not designed for someone who is 90. They weren't designed for modern mobility equipment.

Many of those groups are now saying let's build another project, and let's do it for aging in place and for the ability to provide some care. The issue becomes, how much care? and how can we put together a package of funding to support that? Their ambitions are similar: we want people to live comfortably in the community for as long as they can without having to transition. *They never mention co-housing as an administrative and governance option.

Lynn Pfeffer: I have been questioning why there is little consideration of community living. I think that the capitalist system that we live in is oriented towards individualism, ownership, the nuclear family. Community living seems to be counter this culture.

The advertising for new housing is directed to young families - the family unit is still top of the thinking. Our demographics have changed with an increase in divorce, with spouses dying, with more single women, elder orphans (people who never had children) - all of these changes are not being addressed.

Jamey Burr: This is interesting. In my work with seniors' groups I deliberately bring this out. We talk generically about seniors - very much in line with what you just described-it's false. Visit a seniors' housing project and you immediately find that at least 85 percent and sometimes 100 percent of the residents are women. And what is the economic background of these women? They have a low income.

Why? Because our pension system has let them down. They played the role of caregiver for the family, they didn't work, they don't have pensions, they've lost their husband through divorce, or death, and now they are in a bad position. When framed that way, people's attention just snaps. 
Lynn Pfeffer: When I raise this issue, people say, "oh, come on, it's changing”. Maybe it's true. The boomer generation of women who are becoming seniors - they're not the ones that are 80 and 90 in these homes.

Jamey Burr: It will get better for every generation.

Lynn Pfeffer: Baby-boomer women mostly worked, they had decent incomes, they have pensions. They won't be as poor.

I don't believe money is the only thing we should be talking about. We need to talk about how our wellbeing is compromised. We're going to be 20 years in some elder residence where we feel we have no agency over our own lives, where we don't make true friendships, or connections, where there's still a sense of isolation even though you're in a home with many other people.

All of these are important considerations; it's not just about, we want to keep your heart beating until you're 90 years old. It's a medical model of, "as long as you're alive and you've got food and a roof over your head you're doing well". There's isolation. There's depression. There's dementia; there are all kinds of other things happening.

Jamey Burr: In the evolution of social housing, *governments indicated that housing and health needed to be kept separate. Mostly because of the federal/provincial dynamic; there was a huge fight between provinces and the federal government over health care spending. The federal government held the trump card in the sense of, "this is how much we choose to give to you." There were conditions on how this money could get used.

The discussion was fraught with difficulty and it was felt important to keep housing away from it and not contaminate the discussion.

I talked about the responsibility for choosing projects moving from federal to the provincial government; what do you think federal M.P.s thought of the housing programs once they learned they had no influence and that 75-cent dollars were being given away to provincial governments often whom were of the other party? When I was working in housing, my superiors told me to scrutinize what was coming in from the provinces and to make sure they weren't stealing money from housing to use on health.

What might that look like? It might look like a clinical space inside a building. Oh, you can't have that. Why would we deny seniors the right to be able to walk in 

rise towers around Ottawa that were built specifically for seniors. Researchers in the health field were doing computer mapping and they plotted the incidents of 9-1-1 calls. They found these 11 blocks made the highest numbers of calls, and they couldn't figure out why. They looked at their population health indicators and asked what is going on?

We went to visit the addresses and they were all the seniors' housing. What kinds of medical emergencies were occurring? Anxiety. Falls. People were living in these environments with no support; we took care of certain parts of their lives and completely ignored other parts. They were sick environments.

We're talking about publicly-owned, publicly-funded buildings. The poorest of the poor, people with the fewest resources and the most problems, and we did nothing to help them except say, you've got a roof over your head and a low rent.

These people were living in fear. Many of them were newcomers to Canada. They had poor language skills. They would receive an official document, and would think, oh, my God, I'm being deported. People who are afraid to leave and go shopping, so they're living on meagre rations. They had no support network in the community. They didn't have relatives, family, or friends.

The government began investing in "animation" in 2007, putting nurses and care workers in the building, trying to stimulate conversation with breakfast clubs, etc. Ottawa West Community Support, a community organization was charged with going in to these buildings to help out.

I was on the board of Options Bytown a supportive housing group, which provides help for people with mental health and addictions. People there have their own housing, but if they have a problem there are case workers to help them out. Otherwise, they would risk losing their tenancy and end up back on the street.

Ottawa Community Housing, in their wisdom, said we really like what you're doing; could you come in to our buildings and do the same? Absolutely. We started in three, or four buildings, now we're in 17 of the OCH buildings. We simply have an office where staff are willing to help any tenant with a problem. There are also community resource centres within these large public-housing buildings.

All this is to say there was this terrible legacy where we didn't support the provision of health care within affordable housing. The current approach by the provincial government is to invest heavily in home-care to help keep seniors stay in their homes as long as possible. 
Lynn Pfeffer: I think that's also heading in the wrong direction. Not that there isn't something to be said for home-care, but when I look at my mother's friends, they're living alone. They keep calling each other to make sure each other is okay. It doesn't make much difference that they have somebody coming in for a shower twice a week.

I don't think that's the answer. Looking at cohousing as an alternative to the institutional old-age residences - if you're in a community where you've got friends where people are looking in on you, where you're not isolated, you're happier, healthier, and you stay out of the health-care system 8-10 years longer than seniors who live alone.

Besides this, just because some seniors have the money to pay rent at a private senior residence doesn't mean that the quality of their life is good.

Jamey Burr: Yes. This gets us right in to the whole senior cohousing scenario; what is holding Convivium back now?

Lynn Pfeffer: Personally, I think, it is how little we know about the development process. I interviewed Ronaye Matthew recently, and her (cohousing development consultant) perspective is that the development process is so complex for a co-housing group that without a co-housing development consultant most of them fail. Only one project managed to do it - in Vancouver. All the rest have fallen by the wayside; what does that say? A co-housing development consultant is crucial; but there are none out east.

Jamey Burr: The bigger question that I can't answer is, why isn't it more popular? Is it just a matter of communication? I mean how do ideas get shared?

Lynn Pfeffer: How does cohousing become something that people are thinking about at the government level? How does that happen?

Jamey Burr: There's an unfortunate tendency in the housing movement to portray one niche as better than all the others. The guiltiest, in my opinion, is the co-op housing movement; they like to criticize non-profit co-op housing where you have a sponsor group that owns and manages the building and people are tenants. They talk about their model as better. That's a nuance that most of the population can't understand and, couldn't care less about the difference between this kind and that kind. 
How can you communicate the benefits of living in co-housing to others? You have to have a conduit; is the conduit a faith organization because they have a proven track record in senior housing - they have the credibility?

Lynn Pfeffer: In my opinion, we should consider that those who would be interested in living in senior cohousing may not want to ally themselves to a faith-group; we may need to look for a broader lens than a specific faith organization for some groups

Jamey Burr: We're only just outlining more problems, because one obvious route has now been taken away from us for personal reasons.

Lynn Pfeffer: I understand. Faith organizations are more likely to succeed in creating a housing project, with the support of their congregation. They have the financial capacity, the land and the residents. They're in a better position than housing groups who are not affiliated with a faith group. But there have been five cohousing groups in the last two years that have not been able to get anywhere.

Jamey Burr: Let's talk around this. I described how an organization with competence, like Cahdco, would work with a group for a price. That's another solution. A cohousing group could interview Cahdco and ask, "could you tell us what you would do, what would be the path to success, what is impeding us and what is helping us, and what resources do we really need to bring forward and when?" That kind of plan.

Lynn Pfeffer: If you were to look at the efforts of Convivium Cohousing to get a project going over the last few years, what would your assessment be regarding these same questions?

Jamey Burr: My observation is that you had a group of qualified, interesting people, who had strong views on everything, and that the ability to come up with a compromise that could satisfy everyone was almost beyond expectation. You never got far enough to be able to identify what the trade-offs would be.

This is a blunt instrument at this point, hard for anyone to conceive of -would I be happy there? You can find reasons why you wouldn't be. But real estate is a series of trade-offs; would it be better anywhere else? That's the perspective that you don't have. You don't know until you try it out. 
To find a site that fits Convivium's requirements to be in the centre of town is going to very difficult. Do you want to end up in suburban living? I think that probably violates other key objectives of this co-housing group.

Finding a piece of property is hard. If Convivum did go to Cahdco and say we're willing to pay you \$30,000 to help us, the first question would be, and what land do you want? They are aware of different sites. They could introduce them.

There's another group in town I would recommend; a woman named Joanne Jackson. Her firm's called Jackson-Brown and Associates. She's a broad thinker as well.

Lynn Pfeffer: Do you have other suggestions or feedback based on your experience as a consultant with Convivium?

Jamey Burr: While I was associated with Convivium we were looking at different models and resources. A decision was made, that the group may want to re-visit, around whether, or not, the group would apply for funding through a government-run program, which would mean taking people off a waiting list who are of low income. The response was that this would mean that you "would have to live with strangers"; these were the exact words I heard somebody say when this idea was rejected.

That should be re-visited. If one of the goals is to help older women, who is more in need of help than a low-income older woman; what would be tough about welcoming a few of them in to the project? They're not evil, they're not going to sell drugs. Their only problem is that they have a low income. I think they would love to be in such a healthy environment. The financial upside of that is huge; grants of up to $\$ 150,000$ per unit.

Lynn Pfeffer: In my opinion, the issue raised was not so much about what income level the person would come from, but more about whether their interest in living in cohousing was solely economic, or whether they would embrace the philosophy of cohousing.

Jamey Burr: I don't think it's a problem at all. The cohousing group would have an interview process and say, this is what it means to be here and tell us how you would fit. 
Lynn Pfeffer: Would a cohousing group have to accept the person if they didn't seem to be a good fit for the group?

Jamey Burr: No. Co-op housing can negotiate exactly what kind of arrangement they want. They would say, if you're going to live in a co-op there's an expectation that you contribute by volunteering your time to do certain things. They have a way of screening that matches them up with the people. I think Convivium should re-visit that decision, because it could make a huge difference to your bottom line.

I have great admiration for one of Canada's preeminent developers of co-op housing, Lynn Hannley. With all the government program changes, her organization said there may be a time when we have to move away from government programs as a way to provide housing for 'our' people. They believe strongly in co-op housing and have a long list of reasons why. They felt there was a niche for equity co-ops.

Lynn invested money from her organization to get legal documentation. When the government programs got cut, and C.M.H.C. was still there, they said we need to have people to work with community groups to help them find new ways to build housing. I was put in charge of that. It was wandering into a fog. You gravitate towards people who have ideas and Lynn Hannley was one of those.

Lynn's basic philosophy was that if you're going to try something new and unproven do it with rich people, because they have resources, they understand, they can access lawyers and other professionals. They will be your pilot project; you then have a template that you can replicate for lower-income people. She got torched in the co-op sector for doing that. It was an absolute violation of the fundamental convictions of co-op housing - to be creating housing for rich people. They didn't listen to the rest of her argument. Lynn said, "all right, whatever", and did her own thing.

Those co-op units trade on the open market. She created a form of tenure that could be sold. It could be mortgaged. You could interview prospective residents and ask if they understood that it was a co-op and would live by co-op ideals. Maybe it's just a great place to live at a really good price.

Co-housing will take it a step deeper. You have other behaviours that you hope people will model. Lynn successfully introduced a brand-new tenure type in Edmonton by experimenting on the rich.

Her group is called Communitas. She has done some co-housing. She had groups in Alberta that were keen on cohousing and turned to her. They said, we know you're not a co-housing consultant, but you know a lot, can you help us? So, 
she did. She sees the distinctions between co-housing and co-op housing as being minor. This was 20 years ago, at least. I don't think it was a senior-specific project, but Lynn Hannley is the most knowledgeable person in Canada on matters of affordable housing.

I see this all the time. Somebody is doing something good, and the reaction is, "wow, we couldn't do that for the following reasons..." The question is, what can you learn that did work?

Jamey Burr: I used her website to draw information. She has all her projects profiled. She's skilled at understanding how to go from point A to completion - what the pitfalls are, and the best way to get through them.

Cahdco has had a hard time because CCOC has a specific philosophy of what housing is. When they first discussed senior cohousing Cahdco said, we don't believe in senior-specific housing, seniors should be mixed into community with everyone else; the healthiest community is always the one that has the most diversity. If you create a seniors-only building you are decreasing diversity, therefore it's not as good a project. But to run a successful consulting business you have to accommodate your clients' interests when they have a different perspective. It's taken them a few years to come around to that.

Lynn Pfeffer: There are other senior-focused cohousing groups that are interested in creating more diversity by including younger people. I don't think most seniors are conceptually against diversity, but I believe there is something to be gained by a focus on senior cohousing.

Jamey Burr: Another tip on the search for land. Ottawa Community Housing is land rich. They have two significant parcels inside the city.

One is the site they just purchased from the federal government in between Somerset and Gladstone, just east of Preston, beside the Gladstone Theatre. The Federal government used the seven acres of undeveloped land as a supply depot, and OCH bought it all. They are now starting the design discussion with the community. They will not use all of the property; at some point, they will sell portions for others to develop. The school board has already said it needs part of it.

I know people who live in the neighbourhood; they're excited to see this dumpy supply yard turned into a community. OCH has much the same attitude towards community as this neighbourhood has. 
The second is on Gladstone as you climb the hill towards St. Anthony's church. OCH owns a large number of old two-storey townhouses. They're going to be torn down and two blocks will be redeveloped. Again, their goal is to have a mixed-use.

Jamey Burr: One would speak with Barron Myerhoffer. His primary job is to create new development for Ottawa Community Housing. In the past, new developments have been solely owned and managed by OCH. Now he has the freedom to strike new partnerships with other organizations. They've had one successful partnership with the Carlington Community Health Centre that was operating out of a dilapidated school-house. They're going to build a new community health centre on the ground floor and 40 units of seniors' housing above.

This is a ground-breaking partnership of the health and housing worlds. The health professionals at the Carlington Community Health Centre had no idea how to plan and procure a new health centre; Barron provided the development expertise for that. He's open to discussions with community-based organizations.

Lynn Pfeffer: How do you think OCH would respond to a proposal that is not actually an 'affordable housing' project?

Jamey Burr: I think one could ask the question, what would be the pre-condition for getting involved. OCH doesn't want a re-creation of the monolithic low-income projects that they inherited after amalgamation. If there were better ways to produce housing they would be open. I would like to see cohousing embrace a concept of affordability over the long-term. This doesn't help the founding group but could be part of the legacy of a project.

Some organizations have an immediate visceral reaction to the idea of partnering with OCH. They have a preconceived notion about a bureaucracy that treats people badly. I understand that those conflicts go on, but I look past that. When you manage 15,000 social housing units you will have these issues on a daily basis. The real question is who do you want to go in partnership with?

Barron's statement to community groups is that the taxpayer has paid for the creation of OCH's development expertise and there's no reason why taxpayers shouldn't take advantage of it. If OCH saw the prospect of creating something new with a group, it would do the development consulting at no charge.

Lynn Pfeffer: What might an agreement with OCH look like? 
Jamey Burr: OCH would produce a memorandum of understanding that was noncommittal, saying, we are two organizations that agree to work together to explore possibilities; it's non-binding and we could each walk away from this at any time. You need at least that level of commitment, so OCH can start spending money.

As an example, one group said, we know nothing about housing development and you know everything, there's an imbalance of knowledge and power here; we are going to hire someone with our own resources to be at the table to represent us. They interviewed consultants and chose one.

If a group is going to work closely with a housing provider, they need to be armed with knowledge, whether from their own volunteers, or by paying someone to help.

I wrote the business plan for the group, saying this is what we're trying to accomplish, this is our vision and what we want to build. We had an architect give us rudimentary designs and we were able to put some costs to that. The group would have to fund-raise two and a half million dollars, which they weren't capable of doing.

OCH said, we will self-finance this, we won't need any interim financing and we'll re-mortgage the property once it's finished. The group needs zero equity. It went from being unlikely to a very good prospect. In this case, the group's concept was a perfect match with OCH's mandate to provide housing for low-income people. He was willing to extend these advantages because the group was trying to do exactly what $\mathrm{OCH}$ was trying to do; to reduce the wait list for people looking for affordable housing. He wouldn't extend all of that to a group if they weren't doing that.

Lynn Pfeffer: Does OCH have any relationship with CCOC?

Jamey Burr: OCH is owned by the City of Ottawa. They have a board of directors that is comprised of city councillors. They're an arm's length corporation; certain decisions they can make themselves, others they have to get approval from the board. But it is a creature of the City of Ottawa. Saide Sayah manages the funding programs. OCH has to apply for funding through Saide's RFPs, as does any other organization.

They are highly successful in receiving funding. Many people in non-profit housing think it's an unfair relationship; one arm of the city applies for funding to the other arm of the city. OCH would argue that that's not true - their projects can stand on their own. One big difference is that the taxpayer is paying OCH to do this work. At the end of the day people are coming off the wait list. 
Lynn Pfeffer: That would be another argument for having affordable housing within a senior cohousing project. In a partnership, would OCH be doing the development?

Jamey Burr: If a group had a full partnership.

The lightest level of partnership would be if they agreed to sell a piece of land. If a group wanted to take advantage of OCH's development capacity and work together to solve a social housing problem that would lead to a different kind of partnership.

My current job is to help community groups come forward. I've put about twelve ideas to Barron; once he digested those twelve, he said, "there are groups here that have land and capacity and are a quick win, but, it is more valuable to apply our capacity to help the groups that have none." I said, "that's great, that's where I'm going too."

I would portray a cohousing project as partially self-funded and partially funded by other sources; but the big gap is development capacity, and access to land. 


\section{Interview with Saide Sayah}

Program Manager, Affordable Housing Unit, Housing Services Branch, City of Ottawa. November 15, 2017 (length 2:01:08)

Saide Sayah: There are different ways in my mind that co-housing can work. So, for the purposes of our discussion, how do we want to define co-housing?

Lynn Pfeffer: The word co-housing is itself more of a description of a lifestyle choice. It's not a legal term like a condo or co-operative, which are forms of legal tenure. Those are different things to cohousing. Co-housing has to do with the choice that people want to make regarding how they're going to live. And for senior co-housing, it's going to be mostly seniors, in our case, all seniors, but $55+$.

It's also about how people live, in the spatial sense. Usually, each person has their private space, but the private space is less footage than it would be in a typical condo apartment because you're going to share common spaces and amenities, whether it'd be laundry rooms or a big kitchen downstairs or a living area - like a social area or café - whatever. So, there's this sense of common space.

The design of the building is such that people will have opportunities to meet each other spontaneously and to interact as a community. I live in a condo building right now and we don't even know our neighbours. The building is designed so that you don't cross paths. The only place we cross paths is in the garage; and this is not a place you want to stop and linger, because you're in a hurry, either to get going or just arriving.

Usually the principles of co-housing include a consciousness and a desire to understand what it would be to build sustainably and to be energy efficient in your approach to design. I'm trying to think what other things off the top of my head - it would also be a community of co-care at the senior level.

One of the reasons for seniors to look at cohousing as an alternative is because as we age our needs change and our reliance on other people, in terms of support, increases. Most seniors right now, especially older single women who are living alone in their homes, just don't have that support for one another. For example, in 
my mother's case - who's 95 - the number of friends she can turn to, are dwindling. Anyway, you get the idea.

Saide Sayah: My role with the city is to facilitate the flow of funding that we receive - the affordable housing funding - into city priorities and into the housing sector in the community and the City of Ottawa. Those priorities change from year to year, and one of your questions is how those are set.

Those are set by a number of factors. One, the federal/provincial governments set a number of the priorities. For seniors, we typically have senior specific funding when we receive our allocations; they and Council typically instruct us to use a certain amount towards seniors.

\section{Lynn Pfeffer: Is this funding coming from the provincial, or federal level?}

Saide Sayah: It comes through the province, but it would have been negotiated with the federal government. Then the province agrees to those terms and then pass those terms on to the city in the form of an affordable housing funding agreement.

The highest priority for the City of Ottawa has been housing homeless families. I think from my interactions with the province, our focus at the city level is a little bit different when it comes to affordable housing. It's not that there isn't a need for affordable housing for seniors; I just wanted to stress that we do have other priorities competing at the same time.

For example, there's a high need for affordable housing for families. There's a serious shortage of housing for families, especially families where someone has a disability. We've got a backlog there as well. We look at how quickly people are housed on our centralized waiting list in Ottawa; we find that seniors are housed faster than most other groups.

But, having said that, we do invest in a number of seniors housing projects. Recently, there was a proposal from the International Order of King's Daughters and Sons; and that project's been funded. Another project is in the Village of Sarsfield; it recognized the need for independent seniors living in rural areas. 
With Ottawa Community Housing, we're funding a new seniors building attached to a health hub on Merivale Road as well. Some of the projects that have been completed, just to give you an idea the Perley \& Rideau and Bruyere Continuing Care; those have been completed for a few years now.

From an architectural standpoint the latter would have something that almost resembles a co-housing model. They developed these units for people with early dementia; they're studio units clustered around a kitchen, living area, and with some additional space for support service staff.

Lynn Pfeffer: Which project did you just describe?

Saide Sayah: This is both Bruyere Continuing Care; Bruyere on Hiawatha Park and then Perley Rideau on Russell Road. They both have what they call 'cluster units'. And with Perley, leased two floors from them and these cluster units for what we call 'domicillary hostels' or 'residential care service homes'.

Lynn Pfeffer: Are most of these projects based on whether or not you qualify for affordable housing?

Saide Sayah: This is really the trick when we talk about co-housing, as well as other organizations that come to talk to us, like Convivium. The majority of our funding comes from federal and provincial governments. We are directed towards people on the centralized waiting list. So, these are lower income households in the city of Ottawa.

Typically, when we get approached by residents from The Glebe, Ottawa East, Barhaven, we're talking about households with relatively higher incomes. They probably wouldn't qualify for our housing programs.

Lynn Pfeffer: Okay, so this is taking people off the centralized waitlist. What in general are the criteria for being on a centralized waitlist?

Saide Sayah: It's mainly income. There are some other special priorities: homelessness; urgent medical needs; victims of violence; domestic violence; etc. Our median income for seniors is under $\$ 20,000$ a year for seniors on our Central Wait List (CWL). Now we structure our new communities, to have mixed income. 
We would subsidize a portion of the building; for example, a 100 unit building would have 60 of the 100 units as what we would call 'billable market runs'.

We would then lower the rent with the housing allowance - or other subsidy - so the households on the centralized waiting list can afford to move in. Then 40 percent of the rents will be at the average market rent or maybe they won't be funded at all. But they'd be part of the overall project so that the landlord or the co-op could charge a higher rent for those particular units.

The benefit of those units is that you can provide a mixed income community. We may ask you to do an income test, but it wouldn't be the same income test that's on the centralized waiting list.

\section{Lynn Pfeffer: And what would you call that type of housing, then?}

Saide Sayah: I would say the below-market rent housing is anything that's at the average market rent or less; the average market rent is defined by CMHC. I'll send you a copy of our RFP and that has a rent table at the back.

If you're getting funding from us for 100 units, we would want all those units to be at a certain affordability level. But let's say you want 10 units where you want to charge whatever you want for rent, maybe \$1,500 a month for a one bedroom; then we could make an agreement where we don't fund those 10 units, but we fund 90 out of 100 .

And then you could have your co-housing floor maybe on one floor of the building. So, there are ways to accommodate this.

One of the things about our priorities is we do have a 10-year housing homelessness plan, which is mandated by the province. So that does set our priorities but to be honest, our priorities are 'everybody'. It's households with children, it's with people with disabilities, seniors. It's single men and women. It's single parents.

Lynn Pfeffer: Where in that 'everyone' do seniors fall? Because the number of seniors is increasing exponentially right now and within about 10 years, it's going to be about 30 percent of the population. These seniors are going to be mostly people on their own, because by the time they've reached old age, their spouses have died, their 
children have moved away. In the 'old days' families used to look after their seniors. Most of these people are not in an income level that can sustain moving into an old age home of $\$ 4,000$ to $\$ 6,000$ a month, which is what they're going for right now. Where are they going to live, and how are they going to live?

Saide Sayah: We're trying to provide as much choice as possible. About 4-5 years ago, we had a number of working groups through the City's Older Adult Plan. We had a seniors' forum and what we found was there are misconceptions out there that all seniors are moving to seniors' residences. seniors we find are aging-in-place; many of them who own homes prefer to stay in their own homes for as long as possible.

Lynn Pfeffer: Was the question of why that is, discussed? Because that's a really important question to ask the seniors; "why, are you preferring to age in place?" I would bet that is because the alternative is to go into an old age residence, which they don't want to do.

Saide Sayah: I'll let you know what programs we have in place. We provide a portion of our funding to help seniors age-in-place if they want to. Again, it's income-tested and asset-based. For seniors who require accessibility modifications like a ramp, accessible washroom or kitchen, we would pay for almost 100 percent of that. We provide grants and loans to do that.

That program is called the Ontario Renovates Program. All cities in Ontario are able to do it. Most of us only provide it to seniors and people with disabilities. The other thing we do is we build what we call visitable housing, because we also find that seniors don't want to live in seniors only residences.

We just finished with Multi-Faith Housing Initiative, a 98-unit development in Barrhaven. There are two apartment buildings there. All the units have at grade access and are visitable. We expect a number of seniors to live there as well in the apartment buildings. Beaver Barracks, CCOC for example, down by the Museum of Nature, is a place where seniors live because it is an accessible building.

When we work with our support agencies in the community - with the local health integration network and all these other agencies - our strategy is that we will still have seniors only buildings, but we also want to fund geographical concentrations of 
seniors. We want more communities like Beaver Barracks or like Multifaith Housing Initiatives in Long Fields that help people age in place in their communities. Maybe if they're in a townhouse, then they can move to an apartment, etc.

Same thing with Ottawa Community Housing, when they look at the redevelopment of their different portfolios; we'll be integrating all of that. It just makes for a better community because about 10 years ago, we couldn't fill our seniors' buildings. We were moving younger singles in and it was causing issues. Now, we're seeing an increase in seniors. It's not like a tsunami of seniors coming through in the centralized wait list. But again, we are housing them faster than any other group.

\section{Lynn Pfeffer: Why is that that they are housed more quickly than others?}

Saide Sayah: Seniors make up about 20 percent of all the households on the waitlist. One reason is that there seems to be a better balance between seniors housing demand and number of stock for them. They also have other options: they will be eligible for other non-seniors housing options, housing allowances, rent supplements in the private sector as well, seniors only buildings.

From a development perspective, seniors' buildings are the easiest of affordable housing buildings that are put in our community; we don't get NIMBY and things like that. We still get some

We work with local partners and agencies. We work with the private sector, retirement home operators. We meet with the hospitals, we work closely with the local health integration network, the not-for-profit sector, you name it. This department probably works with over 250 organizations. We have the capacity to build between 100 or 200 units any given year.

Lynn Pfeffer: You mentioned the private sector and senior residences, but are you also partnering with the non-profits?

Saide Sayah: We actually don't partner with the private sector too much because we find their affordability doesn't match the not-for-profit sector. We tend to partner with the not-for-profit sector more, however we select organizations through a competitive process as well. 
We typically release a request for proposals. It would be for something like seniors housing. That would be an opportunity for cohousing proposal to come in but then there are challenges. I see some big hurdles for a group like Convivium to get things going because it takes many resources to get a project like that up and running. When you're dealing with individuals and finances, there's risk.

\section{Lynn Pfeffer: So, you see many issues for a senior cohousing project?}

Saide Sayah: I see significant hurdles. I think your original idea to find a builder who would build a turnkey development, and market it that way, is your best bet. Somebody to create the environment and take on that risk. I think it's more difficult if you try to go the equity co-op route.

It's more likely you're going to have conflict or it's going to look riskier from a financial perspective.

Lynn Pfeffer: If a group was able to prove to you that they managed to get a credit union or a bank to fund them as a co-operative structure? What if the bank has done reviews of each person's finances and have shown that they have equity in their homes that they plan to sell to invest in a new unit; are there ways to help the city see that it's not the risk that they may imagine that it is in terms of people's finances?

Saide Sayah: Well, you could probably reduce the risk, but you still have to find other partners. It's challenging to bring a group of home owners together in an urban setting to finance a cohousing project. It takes organization and upfront investment. You need a group of people willing to financially invest themselves.

I don't know if it's financially viable to ask people to do that without having at least a developer onboard whether it's not-for-profit developer or a private sector one where it's part of a larger development. And to sign some agreement of purchase and sale or something along that line to pre-purchase units or lease them.

There's a high cost in just getting land ready for development and starting construction. Organizing that would be a daunting task for a group of residents who want to achieve a project. From the city's perspective, just the initial start-up 
funding to do all the studies and get through the approvals and building permit, you'd be pushing $\$ 1$ million+. Again, depending on the scale.

Even with the not-for-profit sector and the private sector, we see projects struggle financially after they're constructed.

Lynn Pfeffer: And why is that?

Saide Sayah: One of the reasons is management. Managing a multi-residential building is difficult; it requires work and administration. We see projects come very close to going into default. They're missing mortgage payments and dealing with governance issues. That's something else that we're looking at and we're very cautious about creating new organizations.

You'll reduce the risk if you can hand that off to a larger more experience housing provider or developer. If you have a group of residents who want to lease two floors in a new building or even Ottawa Community Housing or Nepean Housing or whoever. That might be a way to do it, or with the private sector. But you need to find those economic efficiencies to operate.

We've subsidized 70 to100 unit buildings and they can still have trouble financially. You would think you're getting millions of dollars in grants, it should be easy. It's often not, you get hit with surprise repairs, there are utilities, property taxes, etc., mortgage payments, and unforeseen expenses.

Lynn Pfeffer: One of the important principles of cohousing is the idea of a self-managed community. In other words, it's not like an old age residence owned and managed by others; cohousing is owned and managed by the people who created it. That's an important aspect for the seniors that are coming of age now, the baby boomers.

The baby boomers are now somewhere between 55 to 75 years old. They are not inclined to want others to take over control for them. One of the reasons for wanting a model like cohousing is so that they can continue to manage their own lives and make their own decisions. In terms of being integrated with a larger housing provider, I am not sure you would get a buy-in. 
Saide Sayah: There might be opportunities to self-manage. One organization we funded, Eastern Ontario Christian Seniors Co-op; it was a Dutch co-op on 222 Viewmount Dr. The staff and director did, and continue to do, an exceptional job in organizing their own services. They had a doctor's office in their building. They organized it themselves. They found a doctor to come in, they had an agreement with the pharmacy, to deliver medications. For a long time, one of the residents was a nurse who had a part-time job working in the doctor's office to coordinate things. The local grocery store sends a bus to pick residents up. They have a hairdresser that comes in. This is all coordinated by the members.

There are two phases to this project. There's a new building that we funded, then there's the older building that's a federal co-op. One's a federal co-op and one's a city administered co-op, under the same organization. In the older building, people are much older, well into their 90s; in the newer building, they're younger because they've just moved in. That's one example.

I have to give the membership and executive director so much credit. I think she (the ED) was there from the beginning - probably 25-30 years ago. With smaller affordable housing providers, it can be one person that is making it all work. When that person leaves, we can often see the organization go into a crisis. We are very aware of that here at the city. I'm coming back to governance and organizational capacity. It's very, very important.

Lynn Pfeffer: What you are pointing out, is important for any group who wants to consider building cohousing. Issues like governance structure are really important. For example, if you have one person who's the burning soul for the group and they leave, what's going to happen?

Saide Sayah: Regarding seniors housing options; we hear from many communities in the city. Many ethnic and faith groups come to us for seniors housing: the Coptic Church, the Greek Orthodox community, the Portuguese, the Chinese, and so on. Some of them have come to us with very significant resources; they've come to us with land, with fundraised money, but they don't have experience operating an apartment building. This is a red flag for us; I can't stress that enough. 
Lynn Pfeffer: In terms of the larger picture, say for instance, in the National Housing Strategy, again, the sector that it emphasizes is the lowest income. I know this is your unit, and your mandate is to create affordable housing, but, what I don't see yet in any new strategies is something that deals with the moderate-income person. It's not the moderate-income senior that it takes into account; it's mostly the lowest income senior. I'm glad that they're being looked after; I have no problems with that. But the alternatives are few for the moderate-income senior.

Saide Sayah: For the mixed-income communities - if you look at the rent scales - we try to target the moderate income. To give you an example, you can live in Eastern Christian Seniors, you can rent what's called an average market rent unit. You can have a one bedroom there for about $\$ 985$ a month, plus utilities. You could live there. You can apply.

We have percentage of those units for moderate income households. You can live there. With the Perley-Rideau Veterans, their last development was 139 unit; we subsidized 45 out of 139 to help make it viable. They got about $\$ 5.5$ million from the city. We administer 45 of the 139 units; the rest are in the community, they control the list. Bruyere Continuing Care, same thing; that was 221 units and we subsidized 45 of the 221. So again, that's when I talk about leveraging? With Bruyere, the Sisters of Charity gave them the land, and they came to us for development charge relief, and for capital funding. Then they got low interest financing from Infrastructure Ontario. That's a major project; we're talking 221 units and they extended their long-term care. So that's up on Hiawatha Park.

Even for them, a breakeven rent for a bachelor unit is about $\$ 1800$ and a twobedroom is \$2,200 a month. New construction is expensive, and the rents needed to make it viable can be as high as market-rents. When we subsidize rental housing, we find it sometimes costs us more to build than the private sector, because we need to build for the long-term with lower life-cycle maintenance costs. Some projects use geothermal heating and cooling; that can mean more financial investment.

Lynn Pfeffer: Can you speculate on what would have to happen - what would have to be in place, for a cohousing group to be considered? 
Saide Sayah: It's tough, it could probably happen a number of different ways. If you had a couple floors of a building for example that were designed a certain way to be rented in the market, that could possibly work. But you need to find the right provider.

You run into some obstacles just because, again, your group of households or individuals, you're going to want to have some good value for money, right? And that's a problem for the partnership. You may not always find that. It could be challenging. And what I'd like to learn is maybe how other cities have done that, have balanced that.

Lynn Pfeffer: In British Columbia there are many groups now planning cohousing projects. But always with a development consultant who has all the expertise to guide the group. The thing we don't have out east yet, is exactly that. Groups would have to partner with a development consultant, who wasn't necessarily a cohousing development consultant.

Saide Sayah: I recall seeing some cohousing models looking at smaller wood frame buildings within walkable communities. I'm thinking the cohousing tenure might need to be more straight forward. It might be a condominium tenure with a common house and then everyone's got their own unit. A model like that would be a lot easier to do.

In Ottawa, there is something about our geography inside the Green Belt and the density people expect to get onsite; you're always looking at multi-unit residential construction. It's expensive. You would think that you would find cost efficiencies in high rise buildings, but they're expensive. We find it hard to create family units in multi-residential buildings. Add to that, that with cohousing you are looking for independent units with all this other space. It is a very expensive built form.

Lynn Pfeffer: That's exactly what I am trying to itemize, the challenges. And to follow that with "What could be possible solutions?" I think you're already pointing to some of these by pointing out the challenges.

Saide Sayah: If you can find someone who can develop and build that model - and there are developers out there, that seems to take chances and they're able to do projects 
like this. But again, even with the not-for-profit sector. We're waiting for the National Housing Strategy to come through. We're also working on a number of initiatives in the city.

We'll be putting out RFPs, so there could be opportunities for new developers to come in; we'd be looking for innovative solutions like cohousing. We're looking at these ideas, but what we need is to see a group of residents willing to sign leases, make agreements of purchase and sale on these units. It would have to be in a building acceptable to the residents and the City. I think for seniors we could probably do that. If you look at the Perley model, some of the units are fairly high end. At the Perley, the middle-income and some of our lowest-income seniors are living together, and they tell us it's working out just fine.

Lynn Pfeffer: It's true. I saw that only 6 percent of Ottawa seniors fall below the average income level. What I don't understand is why so many old age residences are being built by the private sector and yet a group of private individuals who have the money, who could buy a condo building that was already built, can't do it! Why can't they do it? I don't get it.

Saide Sayah: It's a good question. With the private sector, it has to do with the fact that they have different kinds of investors behind them. They can achieve efficiencies that the City, or the not-for-profit sector, can't. You're looking at developers like Minto and some of these REITs; they can achieve things that are almost out of our reach.

Having said that, we still offer access to incredible financial opportunities, significant grants. But again, with our programs, your revenues are fixed.

Sometimes these developers have investors that put a lot in, right? And then they are just seeing a return in the long run, or maybe even the short run. They build very different models. Some developers even own manufacturing lines for products that will go into their buildings.

Having said this, I think it's still viable. We've got other seniors affordable housing providers across the city that we continue to work with. We want to keep them viable, and to see them expand. 
Saide Sayah: I think a big challenge for cohousing group is definition. That's a challenge because you have to know exactly what it is that you want in terms of built form and legally how it's going to be structured.

Lynn Pfeffer: When you say built form, are you talking about the design? Are you talking about the legal tenure? The condo tenure has been the most common in Canada for cohousing, but Convivium Cohousing is trying to do an equity co-op.

Saide Sayah: A condo might actually be easier to sell, if you find a developer - the lines are much clearer. Condos can be a lot like co-ops, you just own your unit. I think the condo might be more straight-forward and easier to finance. But you never know, an equity co-op could possibly work. CMHC financing could work too, but you need someone behind you to ensure that it's going to get it built.

Lynn Pfeffer: How might the City be able to help a cohousing group?

Saide Sayah: I think we could maybe help - because we're involved in many different pre-consultation discussions with different agencies. We're privy to a lot; whether it's not-for-profit or the private sector, usually people don't want their plans out there.

We'll try to facilitate partnerships because we do hear from different organizations trying to find partnerships and markets that they could attract. So that's something that we try to do through our meetings and events to bring people together.

For example, if I met with a cohousing group one day and then the next day a provider comes in and said we're going to build another 300 units. They may ask us, "We don't know what to do with these two, three floors, do you have an idea?"

Lynn Pfeffer: There are incentives for affordable housing development on your website; could some of these apply to not-for-profit housing providers?

Saide Sayah: We have a fixed amount of money for these incentives each year. A cohousing group would have to apply with another housing provider, or developer, to one of our RFPs. Even as a sole source, a group could come to us with a project and say, "We're building this. This is how affordable it's going to be. Can you help us?" We might be able to find a way. 
But the truth is for cohousing, we have yet to see a viable cohousing proposal. We've met with different groups, we've talked about it, but there hasn't been a real project for us to consider. It's just been an idea.

Lynn Pfeffer: When you say a 'project', do you mean that the land is there, the building is designed, we have an architect and a builder, etc.?

Saide Sayah: Exactly.

Lynn Pfeffer: Would financing only be for a rental cohousing structure or could it be for a mixed income project? In other words, some affordable and some ownership?

Saide Sayah: We could maybe help leverage the ownership. What we've done in the past for ownership models - let's say development charges were $\$ 25,000$ or $\$ 30,000$ a unit; we could consider an interest free or low interest loan. We would have to go to council to do it that way.

My sense is with cohousing, you're probably going to have folks that are eligible for market housing, not subsidized housing. So, you may end up having those units where you pay for all your development charges and everything else, but it could be part of an affordable housing development and then you help each other.

Let's say it's an 80-unit building, and 20 units are cohousing. Development charges are just part of the overall project and are absorbed; you pay a certain rate. Having guaranteed tenants, or a purchaser, is still worth something; you can take that to the bank. You have to look at the overall cost of construction.

Basically, we could support a cohousing project, but we have yet to see a full proposal. No group has come forward with one yet. Just with an idea.

Lynn Pfeffer: When you say 'support', are you talking about that component of a project that would be affordable housing, or are you talking about that as within an affordable housing project?

Saide Sayah: I'd say it's most likely within an affordable project. I suspect we're going to start to see more seniors' developments with the National Housing Strategy, as time goes on. 
I'll say this as my personal view, not as formal city policy - I see new co-ops as fairly risky. Again, because we're creating new organizations and they've got no other equity, no other cash flow to help them manage the risk. I'd say that's just a red flag. You might be able to find an organization where you could have your own independence within a building, but there's that piece too.

Let's say the MHI (Multifaith Housing Initiative) for example, if you were connected with them early on, they could maybe have made a floor available to you. That might be one way to do it. If you had a group of residents who wanted to live together and signed a lease to rent a floor; it would be a lower risk for everyone. I think that's viable. Take 'King's Daughters and Sons' - they've got 20 unfunded units. You go there and say, "We would like to lease 5-10 units from you; can you accommodate us?" There is opportunity, right? We're always open to asking the sector to collaborate.

About bringing in support services, you have to remember, the way supports work now, supports are linked to people, usually not to the buildings. People get their own independent supports whether it's through CCAC or someone else. As a senior you might have your own support network around you.

If you had a group of people living in one area, you could support each other; in addition, if there's a personal support worker that comes in, maybe they're supporting two or three people instead of just one.

In our request for proposals, one of our other criteria is energy efficiency. We push for it - we think we like the Passive House Standard; we were pushing LEED before and other energy efficiency models. We've got the Passive House happening in a couple different buildings, so, we're curious to see how that's going to work out. All of our buildings are as energy efficient or more energy efficient than what you find in the private sector.

Lynn Pfeffer: In regard to support services, I've heard of cases where if there are enough seniors or enough people in one location, the organization that's contracted to give home support will set up a small clinic or a small location within that building. 
Saide Sayah: I think we're going to see more of that. We've been working with the Local Health Integration Network and we're trying to find cost-effective ways to bring supports to people. We know we're not building any more long-term care and people are living longer, they want to age in place; we have to start bringing supports into buildings. I think it's going to be interesting to see how it all unfolds but that's the direction that we're moving in.

Lynn Pfeffer: I'm thinking about the opportunity you pointed to of a number of units or a number of floors within another project that's already been built. The idea of the cohousing model is also in terms of how it is designed. A building that didn't actually have spaces where people could be together and continue this idea of creating community, wouldn't work very well for a cohousing group because it's not designed for that kind of living. That's the problem.

Saide Sayah: Our supportive housing is a microcosm of what could be cohousing. We've got small studio units, but every floor has its own common room. Cornerstone, for example. That way each floor feels their own sense of community.

There might be cost effective ways to plan that out. What I haven't seen yet from any cohousing group is to just go through an exercise where you design what a cost effective cohousing building would look like in the city of Ottawa. So that you know how much land you need, or how much of a building footprint, how much parking would you need and what kind of construction you are looking at.

It's a realistic idea of what it's going to cost each person per unit, because it's that combined space that adds cost. Are you guys looking at two bedrooms, one bedroom?

Lynn Pfeffer: Convivium did go through that exercise when they were hoping to be in Greystone with Regional. Essentially, they were looking at mixed size units. In other words, some suites, some one bedroom and some two bedrooms; probably a third each. Up to 20-25 units and 35-40 people.

Often the first hurdle in costing is how much the land is going to cost; without the land cost it is difficult to break down the costing of the units. Looking at a designbuild team to help with assessing the feasibility of potential sites is also helpful. 
Saide Sayah: I don't want to commit to having another senior's forum right now, but it might be worth looking into. I know there are some significant developments underway, which could work.

We often host different kinds of forums. We haven't done a senior's forum in a few years and we did promise to follow up on the last one we had done. The last one we did was about 5 years ago. We're waiting for this other building to be done - we promised to do a second one about supports - how to bring supports to seniors with the Ministry of Health and Public Health and other agencies. I could talk to CMHC about holding another forum for seniors.

Lynn Pfeffer: The theme that I feel isn't yet acknowledged by government is the 'quality-of-life' of seniors. Our society, and housing policy, has been structured around the idea of the family unit. How does housing have to be re-thought when there are significant numbers of people who are living alone?

For example, I'm imagining you and your wife and your kids; there's this nuclear family. Everything in the building industry has been geared towards this nuclear family. Developers build houses or townhouses, and condos, for young couples before they have the money to buy a house. But, what isn't being acknowledged is that the make-up our society has now has shifted.

There are people who are on their own because of divorce, family breakup, empty nests where all the children are too far away to be part of the family. A spouse dies, a spouse separates, divorces and re-marry. There are lots of people who no longer have the kind of community you feel in family, unless they're part of a faith group. Faith communities are less popular with people who have been through schoolingthey tend to be more cynical and skeptical.

We don't have community. This whole idea of how we're living is, in my opinion, unhealthy. You hear more now about isolation, depression, illness because of people being isolated. It's like trying to re-think how we live in a more holistic level understanding that as human beings, we need each other, we need community. We're healthiest when we live in community, but we're not thinking that way. 
Even when you look at senior residences, those people aren't in a community. They're not feeling like they're together, working together and co-caring for one another, sharing their lives. That's not the model that a senior residence is based on. It's not what's happening. The whole idea of building a healthy community - and I don't just mean one cohousing project - should be something we consider.

Saide Sayah: We're doing some thinking about what we call mixed communities looking at having a high concentration of seniors living with younger singles and families - that might support transitions for seniors.

Lynn Pfeffer: What also needs some thought is the building form itself; working on the design of the building to reflect the idea of living in community.

Saide Sayah: We're talking about multiple buildings in one community and different needs. We have so many not-for-profits and private sector partners that to be able to help leverage the finances and resources we need to create something much more innovative, including what people are looking for from that social perspective.

From a city perspective, the stand-alone co-op is one of the riskiest investments. They sound great, but sometimes they don't work out well, especially when you're mixing affordable housing with some of the co-op structures. You get different interests colliding. People who believe in the co-op model alongside those needing lower rent. Some of the federal co-ops work better because their rules are lighter. You have to remember our funding is for the lower-income households where people need a unit to rent.

At Eastern Ontario Christian Seniors, the gardening is done by the seniors, the landscaping, the maintenance; they take care of the building for the most part and save money. They bring in other supports in too. I was impressed by how they operate.

Lynn Pfeffer: Fascinating, so there's a level of maturity and desire to work together.

Saide Sayah: The senior element of cohousing could be a benefit in this way. But it's the financial piece that's the challenge. A cohousing group could convince us, and we 
could say, "We think it's a great idea, but we can't give you all the funding. We'll just give you some incentives." The group still has to convince the bank for financing.

Lynn Pfeffer: Being realistic about possible risks sounds important.

Saide Sayah: One partnership we had with the Health and Resource Centre is a good example. They realized that they were not experts in construction. They decided to lease their land for $\$ 1$ to OCHC. And then OCHC's actually doing the project management for them.

They wanted that oversight, and they have good procurement policies. They would use them for the project management. OCHC can't manage everyone's project. Even when you work with private developers, you've have to remember if you guys are buying the units in the building, once the warranty expires and everything else, you're on your own.

Lynn Pfeffer: I understand that the City of Ottawa had an Affordable Home Ownership Program at one time. When did it get cancelled?

Saide Sayah: We used to have an affordable home ownership program. We currently are only funding Habitat for Humanity for home ownership projects. But we're thinking of ways to expand this portfolio. We had it starting back in 2007. When the economic crash happened in 2008 the Harper government made down payments loans available on a first come first serve basis. We just opened the doors, accepted applications and as we received them, we sent them to the province for approval. After a few weeks, the door was closed because the province was flooded. I believe it was all federal money. And the whole idea was to get the residential sector going.

The Province had set aside money for home ownership down payment assistance. Now, we can take money out of our budget to support it. But this is something we could consider, I'll say that in the future. We're looking at bringing it back but right now, we fund Habitat.

Lynn Pfeffer: In terms of procedure, how does something like that get reintroduced? 
Saide Sayah: Well, that's really up to staff and council's direction to create a new program. We did ask for one the last term of council. With the National Housing Strategies and other things happening, we might be able to create incentives for home ownership. It could be possible.

Regarding zoning and zoning by-law changes? I guess it depends on scale and everything else. You're looking at probably 30-40 unit residences. I'd say with 25 units, you'd really want to look at the viability of something small. I would look at construction costs, land costs - build an entire model, a whole per-forma.

We have spreadsheets for that. I work backwards. What would it cost you to build it? How much financing would you need? And then your cost per square foot per unit, what would you would have to pay. That's really what you want to know. Then you might have different land values depending on where you are in the city. Before we look at any land, we'll have someone do a conceptual design.

Lynn Pfeffer: Would an 'apartment style' cohousing building be allowed in any residential neighbourhood?

Saide Sayah: You're allowed in pretty much any residential neighbourhood. You're not a 'retirement home' which has its own 'use'. This is independent living. You'll be looking at an apartment building for the most part, or what's called a 'PUD', a planned unit development. You'll fall within a typical residential zone. The PUD is if you have little townhomes in a cluster. That might actually be cost effective.

If you had a piece of land, the land could be expensive but then everyone owns their unit. The issue there is when people sell, do they sell to a senior or not. A group would have to figure out how that would all work.

Lynn Pfeffer: Cohousing could offer a real solution for some of the socio-economic shifts that we are dealing with as a society.

Saide Sayah: I think we will be supportive, but the city needs more than an idea to go on. We'll be open when we find opportunities; when we think there's a good fit with a partner, we'll reach out and try to find ideas, like the Heatherington example. 
Lynn Pfeffer: It's nice for me to hear that despite your role with the City, and the responsibilities of your job, that you are still reflecting on wider issues.

Saide Sayah: We really try to; our biggest challenge is that we're not going to completely solve homelessness. We've have to be realistic about this. There's migration between cities, there's migration between countries. A complex web of social, mental health, economic and other problems affecting people and our communities. We have to be realistic to create programs that help.

Don't get me wrong, we want to get people out of homelessness, but people have trying to end homelessness since the beginning of time. But we have to invest in it just like we invest in any other infrastructure. Often these programs are seen as a quick fix. I didn't really get into the financial aspects, but the programs today, whether it's in Canada or the US or in Europe, are designed to build buildings with up front capital or grants and little long-term commitment from senior levels of government.

Saide Sayah: My background was in urban planning, design and environment. I wanted to get involved in housing. I didn't know that much about finance; I had taken a few courses in university. I've been here for a little over 10 years now and I'm still scratching my head trying to figure it all out. What's frustrating is everyone thinks there's a magical bullet. They say, "All you need is free land, all you need is grant." You do need those things, but you also need solid governance and to leverage and find those partnerships.

That social part is so critical in having a functional group. One reason why I think groups like Multifaith Housing Initiative works so well probably because it has such a broad based to draw on, it's over 60 faith-based organizations as part of Multifaith. It means they have a really diverse and knowledgeable board. They have people with all these different backgrounds and expertise. You want a strong board with whatever you're doing, you want to make sure that you've got board members with expertise in different areas, whether it's law, finance, project management, construction, planning, architecture, and members who are very accountable.

\section{Lynn Pfeffer: What is happening with the National Housing Strategy?}


Saide Sayah: We're waiting to see what's going to come out. We did have input and we continue to have input. We work with 'service managers' - different kinds of municipal governments. For example, we work very closely with Toronto, Peel, London, Hamilton, Durham region. The cities around the GTA, even the closer ones like Leeds, Grenville; it's quite a network, and we all work together.

We've got different issues that we're each facing but we all have input and we try to have a collaborative voice going into the federal government. The federal government has been really listening to the cities this time. The provincial and federal governments tend to vie over who will have the most influence over city policy, but ultimately, we are the creature of the province - we're directly under provincial jurisdiction.

Lynn Pfeffer: I would think the issues are more imbedded in the cities themselves, so the type of feedback you're going to get from a municipality is going to be different to what you're going to get from a provincial government.

Saide Sayah: That's it; the issues now around housing are really urban issues. Eightyfive percent of Canada's population lives in its Cities. They're struggling, and I don't know what's going to come out of this Strategy. We know there's going to be new financing. I think there are going to be initiatives in the National Housing Strategy for projects like this. That's what we're looking for. What we're seeing is they want to create a spark to ignite that missing middle. Right now, we just don't have tools to do that. The tools we have in our unit are for lower income households. That's why it's not always a fit for a cohousing group.

\section{Lynn Pfeffer: How do priorities come to the surface?}

Saide Sayah: We had asked for changes from the provincial government for how our funding works. There was no incentive to move an individual from a shelter into housing in the past. If you were homeless, the province would cover $80 \%$ of the cost, the City would cover 20\%. Once we moved you into housing, the provincial funding disappeared; we lost our share of funding for taking care of the individuals. The whole system was set up in a way that kept people in the shelters. All the cities went to the province and said, "You have to change this. do something. Fix our funding so that we're not going to lose the money and we can create supportive housing and 
move people into housing." So that's what they've done. They've fixed our funding formula, which is good.

Lynn Pfeffer: Are the homeless usually housed in buildings where they have community, or are they housed independently?

Saide Sayah: They're individually assessed, and the ones who are best assessed for a supportive housing environment are offered supportive housing. The ones that are assessed for independent living in apartment buildings, would go there. People need choice, and some are going to do better in supportive housing.

When it comes to the cost of housing for seniors, I think some of it right now is just the market. I don't believe it's always the actual cost, I think it's the market demand. I would recommend very detailed market studies.

Lynn Pfeffer: Privately-run retirement homes are using up the hard-earned money of seniors who either worked hard or had good pensions. There will be nothing left to pass on to their children and their children's children after spending this money.

Saide Sayah: I think you'll see a resistance to that. My feeling is that you're going to start seeing more options in the market. I know one developer, I won't say who it is, but he lives in Gatineau in a retirement home because it's less expensive there... $\underline{\text { but my }}$ point is that you have to remember, in Canada, we have a market-based housing supply.

When you sell your home, you're going to get best market-price for it. It is a market failure when we run into these situations. We want to enjoy the benefits of having a market-based housing supply. On the other hand, we want affordable housing. This is something that we're struggling with; how do we do that? I'm trying to work with economists to address this at a local level - to help us make better decisions.

Lynn Pfeffer: Many people can't afford housing now. It's okay for those that bought in 15-20 years ago, their houses have gone up in value. Those trying to buy in now are struggling.

Saide Sayah: No, it's expensive. I'm thinking even for myself and my family, we can afford it, but how much are we spending? Do we have to spend that much? Some of 
it's just the lifestyle we expect now. We have different expectations than in the past, higher expectations perhaps.

\section{Lynn Pfeffer: Our expectations are high.}

Saide Sayah: People were relatively happy with war-time housing in the past. I have noticed that in the seniors' projects we've done, expectations are often higher than what can be afforded. All these social things, there are benefits and there are challenges.

I would just note one other thing; the province is asking us to look at more Hub concepts, leveraging co-location opportunities. I think there could be opportunities in the next couple of years to see something like cohousing happen. But my view is that it has to be simple. What I mean by simple, I mean it could still be a nice design, eloquent, with the shared spaces. But in terms of ownership and operations, it has to be straight forward.

Lynn Pfeffer: I would speculate that most cohousing groups would love nothing more than to be part of a neighbourhood Community Hub, where there were other services and where they could become part of a neighbourhood.

Saide Sayah: There are initiatives starting to come together. There are private investors doing their own thing; it's harder for us, we don't have the same mandate. I think what's going to come out of the National Housing Strategy is more opportunities for things like this. 
Interview with Kathryn McCamant

Co-Author: Creating Cohousing: Building Sustainable Communities

Founder and President of 'CoHousing Solutions', Nevada City, USA

Durrett and McCamant Architects

Interview conducted on November 6, 2017 (length 1:01:22)

L. Pfeffer: One reason given for why there are so few cohousing projects built in Canada, is that the cohousing development process is very complex. In British Columbia, more projects are being built than in Eastern Canada; cohousing development expertise is available there, which it isn't in the East. What does a cohousing development consultant need to understand, that a regular development consultant might not?

K. McCamant: It's mainly how to work with a cohousing group of buyers, to organize them and help them understand what it's going to take to be successful. People come to me who want to live in cohousing. They don't want to become real-estate developers, but they have to learn about successful real-estate development in order to create a community because developers aren't creating communities like this.

Jim Leech (in Colorado) and I both worked as developers; we have good models for partnerships between a professional developer and their teams and cohousing groups. I see my specialty as the translation between those two worlds - helping a developer understand how to work with a buyer's group, and not get caught up in the meetings; at the same time helping a cohousing group understand what a developer needs to be successful.

L. Pfeffer: Have you worked with developers who have become interested in doing cohousing projects as a larger part of their business?

K. McCamant: A few. It's hard to convince them. The development company that did PDX Commons in Portland would consider doing more. *The model that I think is the future for the professional development world is not for developers to organize cohousing groups - Jim and I organized groups around properties - but to have developers who have an understanding of cohousing. They could say, if 
you bring me an organized group who's realistic about the cost and what it takes, then I can partner with them.

If developers were more familiar with cohousing and groups had someone like myself or Ronaye as the translator between the group and the developer, partnerships would work. It's not about asking a traditional real-estate developer to figure out how to organize a group, or market cohousing. The group has to get itself organized and have its own consultant. Then, it's a much easier partnership.

L. Pfeffer: In that kind of a partnership, how is the work of the real-estate developer different from the traditional ways of working?

K. McCamant: Developers are used to being able to change their minds. Developers who work on projects of this scale see themselves as controlling the whole project; they move pieces around and constantly change things. That's what you can't do with a buyers group involved; you need to make decisions and move forward. If you can get the ship moving in one direction, it picks up momentum; if you try to turn the ship, it's a big ship to turn. It's not as flexible in that way. It requires developers to be more deliberate than they are naturally when they've got control of their projects.

You don't want your cohousing project to be the largest project the professionals have ever done; that is dangerous! I want my contractor, developer and architect to understand multi-family housing in terms of the building type, size, and costs.

L. Pfeffer: Have you worked on apartment-style urban cohousing projects in contrast to the village style design with detached units? Are there groups doing this?

K. McCamant: There's a lot of interest. The difficulty in popular urban areas is that land is expensive, and you're competing with the big developers. It's difficult for cohousing groups to secure properties in popular urban areas. I was a consultant to PDX Commons in Portland. That's a four-story building, so it's a great model. It's a senior cohousing project. In that case, it was a sophisticated 
group, and the developer that they partnered with had land. They made the decision to work with the developer, but they weren't sure they wanted the property. They looked around and decided it was a great location. The developer already owned it. The complication in most urban areas is the cost of land and how fast you have to come up with cash to tie it up. That has to do with competing with larger developers for the land.

L. Pfeffer: It sounds like that group decided to choose a developer as one of its first steps in the project development. Is that the way you would recommend working - the group (with your help) finds the developer first?

K. McCamant: That's actually rare. Most early stage cohousing groups would scare a developer away fast. I don't think you can expect a professional developer to have the patience to help a group get realistic about what it takes. I build the budgets and investment structures, and get the group moving forward and thinking practically so they can be a reliable partner for a developer.

L. Pfeffer: Do you help in finding the developer?

K. McCamant: I do a lot of putting together partnerships. I understand the financing, the risk and rewards, who does what, the other projects they've done, and what other developers have done. I help find the developer and the professional team and bring them together. I work with the group on approaches they can take and the aspects of that; they can then make an educated decision.

L. Pfeffer: Is it fair to say that you are the orchestra conductor?

K. McCamant: What I'm not doing is on the ground project management. That's a different thing. I'm best practices: here's what you need to do next; here's a membership agreement; this is how you do marketing; how we fine-tune that; what's your cash flow; how you put money in the deal; how you get it out. I'm not on the ground moving the project along. Now, I help the group understand what they need to do, and what team they need on the ground. 
L. Pfeffer: What are the most common reasons that cohousing projects fail? Or the inverse question, what do you think are the most important ingredients in creating a successful cohousing project?

K. McCamant: When people get involved in cohousing, they have no idea how housing gets built and the harsh realities of today's costs. When early-stage groups start looking at a project, they're often so unrealistic about the costs and the initial investment that nobody's going to put the money in for them. Until you have a group that is realistic about money, and willing to put in the upfront cash to say, “we 're real, we're not just talking, we 're committed," it's very hard for a project to move forward. In order to do that, most people need a strong sense of trust with their other community members. That's where it takes time: the initial core group has to build that sense of trust to be able to say, "we don't know all the answers, but we 're confident we can work it out".

There is a significant portion of the population that could afford to buy into cohousing, but they - particularly as they are reaching the end of their working life - should not be taking the risk of real estate development. That's where there's such a disconnect; and that's where government support could help. There are people who would love to live in cohousing, but they don't have the financial resources to take the risk of an early-stage development process.

L. Pfeffer: If you were trying to explain to a potential cohousing member the inherent risks of an early-stage development process, what would you say?

K. McCamant: First of all, when you start a project and put in your money for consultants and land, it's 3 or 4 years to completion. Who knows what interest rates, the housing market or construction costs, are going to be. When I build those first budgets, I don't know what construction costs are going to be two years from now. We don't even have a design yet. I can only project so far out, and there are no guarantees at all.

L. Pfeffer: Are there projects you've worked on where risks materialized, and people lost money; cases where people should not have been investing because they couldn't absorb the risks? 
K. McCamant: With the projects caught in the 2008-2009 crash, there was nothing they could do, and people did lose money. There was no way to get their money out of the project when half their group bailed because of an international economic collapse.

\section{Pfeffer: People lost money that they had invested in a project?}

K. McCamant: As did every developer across the country. If you're not in housing development, it's hard to appreciate - California got hit hard. Canada didn't get hit nearly as hard as the U.S. Every developer lost significantly, many projects went down, and cohousing was a portion of that. Cohousing actually did better through the recession than other typical housing projects.

\section{Pfeffer: How can individuals and the group mitigate those risks?}

K. McCamant: One way is having a consultant that understands the economics of development. People don't realize that market-rate housing has some of the tightest development budgets. You can't afford to spend a little bit more here, and a little bit more there. With common facilities, you are already paying higher costs for the size of the home you get.

The nature of real-estate development is that in a boom your prices can go up, and you can absorb the mistakes. In a flat market, or in a bust, you can't afford to do that. It's important to be able to make decisions and move forward, not rethink things, because time is money in development. Every time you go back and rethink design decisions, it costs you. It's also good to have someone like me who can point out the repercussions of decisions made, or not made, and who can encourage people not to get caught on details where you could argue both sides; "we made this decision, and it's more important to just keep moving."

The other risk for development is planning approvals. Planning departments and commissions are used to dealing with developers, and nobody feels sympathetic toward developers.

I am sympathetic toward developers because people have no idea how much they're trying to juggle, for example, if you are trying to get a re-zoning and you 
have already invested in the design process to get the approval, and then the city requires street improvements in addition to the building itself.

L. Pfeffer: You have an intimate understanding of the developer's role; most consultants haven't worked as a developer.

K. McCamant: Yes. I've been in the trenches; I rode the boom and the bust; I've done every aspect of it myself. I have a deep understanding of the housing development process.

L. Pfeffer: It's wonderful that at this point in your life you're also interested in training others. Tell me about your 500 Communities program.

K. McCamant: I'm excited about the 500 Communities program. It's not just about passing on expertise; it's also about creating a collaborative network. Being a project manager consultant to a cohousing group when you're not part of the group is actually a lonely position.

In any profession, it's important to know who your peers are and who you can talk to. Who do you brainstorm with? Creating a collaborative network is not just training people; I'm looking for something bigger.

L. Pfeffer: Could that collaborative network extend to Canada? Is the network going to be exclusively American? Will we have to build our own in Canada?

K. McCamant: It could include Canadians. This is a business for me; it's not a non-profit venture. Being a part of it involves commitment, costs, and taking part in the network. It's not about who wants to get together and chat. Are you part of the 'CoHousing Solutions' team or not? There was a woman from British Columbia who applied to the program last year. I suggested she consider interning with Ronaye, because we do much of the same thing. It would be better for her because she is there.

L. Pfeffer: Much of the building industry - including developers and investors - is still largely male-dominated. Are the organizational structures of the building sector responsible for any of the challenge of creating a cohousing project? As 
a woman developer, do you need to approach the industry more strategically with an eye to their existing structure?

K. McCamant: Yes, real-estate development is very male-dominated. I don't know if that changes anything as it relates to whether you're a man or women. The nature of real estate development is that everyone is coming at you with their own requirements, and they don't talk to each other, and you're trying to make it work from a lot of different aspects. There's a lot of "I can do anything" and 'fly by your pants' mentality, and guys who think they can do it all. But the better developers are a sophisticated group and are interested in different markets, and urbanscapes, and how to create great spaces.

L. Pfeffer: Another gender-related question has to do with the involvement of women in senior cohousing. I'm not sure if this applies to diverse inter-generational communities, and I don't know if it's demographic - in that there are so many more women than men in senior groups - but I've noticed it is mostly women who initiate and lead projects. Is this true for inter-generational projects. How do you interpret this reality?

K. McCamant: Many strong women are involved in cohousing. I see women initiating and leading cohousing projects, but I also see men.

L. Pfeffer: When it comes to senior cohousing, do you see more women than men taking the lead?

K. McCamant: While there may be more women, it is not exclusively women in leadership roles.

L. Pfeffer: With the origins of cohousing in Denmark, women were trying to find ways of collaborating on housekeeping and childrearing. Is there something about the collaborative approach of cohousing that women would be more drawn to than men?

K. Mc Camant: Women seem to care less about the task, and more about being part of a community. Traditionally, we go to our girlfriends for support. Increasingly, 
men are better at that, but traditionally, they came home from work and their wives took care of them.

L. Pfeffer: I never thought of it that way, but that's interesting.

K. McCamant: Women know that nobody is taking care of them if they don't go out and create support for themselves.

L. Pfeffer: In Canada, the two cohousing consultants that I know of, Ronaye Matthew and Lynn Hannley, of Communitas, are both women, and you're also a woman cohousing development consultant. Are there cohousing development consultants that are male, in the US?

K. McCamant: Chris Scott Hansen has done development consulting and has worked in Canada. And there are quite a few men in the 500 Communities Program.

L. Pfeffer: What's the difference between 'seniors-only' cohousing and the diversity of multi-generational cohousing? What are some arguments for creating a seniors-only cohousing project?

K. McCamant: I've worked with both groups. A key advantage to seniors-only projects is that retired people are more available. In an inter-generational community, people are often too busy working to spend time engaging with the community.

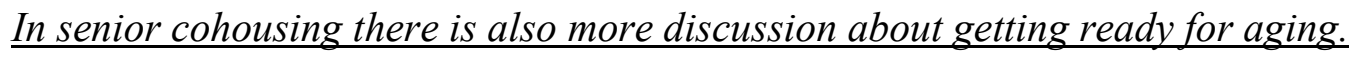

I live in Nevada City cohousing in an inter-generational community. Wolf Creek Lodge seniors cohousing is about ten miles away. I was the developer for both, so I know them well. We have plenty of seniors in Nevada City, especially now that we've all gotten 11 years older. And we've had some deaths. Last year, we lost two members in their 80's. We've gone through the cycles of births and deaths, but we aren't very organized around it. However, at Wolf Creek Lodge they have a file with everybody's medical records, who to contact in the family, and what to do under special circumstances. They also have a more active and ongoing conversation about who needs support and how to administer it. At Nevada City, we're more ad hoc. Because of the lack of hours in the day and people raising kids, we're not as focused on aging and support issues. 
L. Pfeffer: People who are still working are busier with other aspects of their lives, as compared to the person who's retired.

Another question I have involves income disparity. One of the biggest regrets of many cohousing groups is the inability to accommodate low to moderateincome members who would like to live in cohousing but can't afford to buy a unit. Are there models that include this demographic within an urban cohousing project, along with others who have greater financial capacity?

K. McCamant: That's where government comes in. We are forced into a market-rate model because there aren't any other sources of financing.

L. Pfeffer: Are there government programs for affordable cohousing in the States?

K. McCamant: Affordable housing is not high on the current US federal administration's list of priorities. We have a huge problem with the homeless population, and the limited money tends to go to the people with real need: the homeless and people 50 percent below median income. By contrast, in northern Europe there is a much broader social housing movement, and they look more holistically at healthy places to live and age in. They consider housing's effects on both the housing and the health care budget. In the U.S. we don't do that.

L. Pfeffer: Canada may be more socially oriented than the United States, but we don't yet look at housing, health and aging holistically yet.

K. McCamant: I saw that difference in 2009, when we gave workshops in London, England; it was right before David Cameron was elected, and everybody was expecting cuts. It was actually the Conservatives who were interested in how to take better care of elders. There are now studies showing loneliness and isolation are a huge health care issue. They were looking at health care costs and suggested they'd like to put more money into cohousing because they saw its benefits in reducing health-care costs. It takes a holistic awareness to understand that. 
L. Pfeffer: Does the United States have housing departments at federal, state and municipal levels?

K. McCamant: Housing and Urban Development is the federal level, and then the state also has a housing department; California Housing and Urban Development. Then there is CHAFA which would be the California Housing and Finance Agency. There is rarely anything at the city level. Most of our affordable housing is developed by non-profit housing developers who pull together state and federal subsidies and spend their lives trying to figure out what programs are available and how to get the project going.

L. Pfeffer: Canada has more government-funded, affordable housing. Non-profits also build affordable housing, but there is government money for that. The federal government gives the province a certain amount of money, then the province determines where it's spent. If some of it goes to housing, it's managed by the cities.

K. McCamant: The larger cities may identify affordable-housing properties, but even then, their role is small. Very little is done to get more affordable housing built because the cities don't have the funds.

There is interest in cohousing, but housing costs are out of the reach of moderate-income families or seniors, groups with no housing subsidy. Also, construction costs and planning fees for new housing is expensive. Since the recession in the States, most developers depend on the private market to build housing, so they're building for the top-tier markets. They're in business to make a profit. There are the projects that make a good profit, but for every one of those there are several that don't.

L. Pfeffer: In Canada as well, most developers are building for higher income levels. The needs of the moderate-income person are being lost. Moderate-income people who can't afford to buy a new urban condo or house, and don't qualify through 
income level for affordable housing, get caught in between. They would like to live in a cohousing community, but they can't afford to buy in.

K. McCamant: In my workshops, I try to explain that cost issues are not just relevant to cohousing. This is the state of housing. Without additional sources of financing we can't solve the availability problem. People are often misled into thinking that developers are making so much profit that if you just cut that out it would be affordable. That's not true.

L. Pfeffer: People do have that perception. It's interesting to hear from you that that is not the case.

Most cohousing in Canada uses the condo/strata-ownership model. Is this the case in the U.S.? Are you aware of any cohousing projects in the U.S. that have used an equity co-op model? Why has the condo model been the preferred legal structure?

K. McCamant: Because it's what the banks know and will finance. There is no logical reason to use a co-op structure, in my opinion. The banks understand condos, or 'strata title' in Canada. In the U.S., few banks understand co-ops. Using this structure would limit financing options.

L. Pfeffer: Is that the main reason?

K. McCamant: I tell groups that they will have trouble getting share loans. There may be one source in the state, with no competition. If you don't like their interest rates or what they can offer, you have nowhere else to go. The whole financial world got much more conservative after the 2009 recession. Banks don't want to do anything unusual.

L. Pfeffer: Here again, there may be a slight difference in Canada because we didn't have as deep a recession.

K. McCamant: Yes, and you do have more co-ops up there. 
L. Pfeffer: There are more co-ops, but equity co-ops are rare. The city builds affordable housing as co-operatives, but they're all rental units. Limited equity co-ops are not common.

Theoretically, if banks were in a position to fund either model, is there a legal argument for choosing a condo over a co-op?

K. McCamant: I could make an argument for co-ops. The big difference is when you sell your unit in a co-op, your share goes back to the co-op, which has control over who they sell to, whereas in a strata title or condo, it doesn't go back through the homeowners' association. There is no legal requirement that gives the H.O.A. any control over who buys in. That being said, co-ops would be great as long as there were multiple sources of financing and you were never dependent on one source.

L. Pfeffer: Is the concern around dependency on sole-sourcing that the interest rates might be higher because of the lack of competition?

K. McCamant: The source could go away. The banking world is constantly in flux. In the U.S., banks are buying banks out. I expect a building to be there for 100 years; I need to make sure that people can get financing.

L. Pfeffer: That's interesting. I never thought of it that way, in terms of the legacy and people's ability to have the opportunity to buy in.

I understand that finding a person interested in living in cohousing for a cohousing condo unit that is up for sale, doesn't seem to be a problem - despite the fact that legally one cannot discriminate who buys it. How do cohousing groups select buyers?

K. McCamant: When you're buying in to cohousing, you are buying a smaller home for a higher cost. In the market-based economy, there is no advantage to buy into cohousing if I don't want to live in the community, because I'm paying for the 
common facilities; that's in the sale price. The market-rate system acts to screen out buyers who don't value what the community has to offer. They can buy a bigger place for less someplace else. But it also has its limitations.

However, the most important issue is not legal. It's about being clear regarding expectations and conducting a good orientation so that people who are looking at joining - or looking at buying in later-know what they're getting into and what the expectations are.

Groups will say, "We need a first right of refusal when we're at re-sale," but the real issue has to do with how people invest their time. Instead of going hiking on Sunday afternoon, you need to show up for the open house and talk to people about the community and be there to answer questions." In my mind, it's about time investment, not legal issues.

\section{Pfeffer: That makes sense.}

I'd like to ask a personal question. What have been the biggest challenges in your own cohousing experience?

K. McCamant: Whether it's family, or a spouse, or a community, there are times when people will drive you crazy. But there are more times when you think they're fabulous and that you're lucky. I love living in cohousing; I've reaped the benefits in many ways. But there have been times when personal or community issues have made me lose patience with it. Over the long term, things will go up and down; there are times when I'm not as involved, and then I circle back, and I get involved again. One of my favourite quotes is from a woman who developed a project back in North Carolina; she used to say, "People, the last frontier."

L. Pfeffer: You mention reaping the benefits of cohousing. What is the primary benefit for you?

K. McCamant: This is hard to explain, but most people who live in cohousing would understand it. I can't use it in marketing because I don't think people 
understand it, and in some ways, it scares them. Most of my neighbours are not my best friends, and they're not family. But the level of trust-my gut feeling that they've got my back, that I could ask them for whatever I needed, and they would show up for me - is an amazing thing. I think most people don't have that.

Dear, long-term friends are often not close by, and they're not always available.

Living close by as neighbours and interacting with each other over time gives depth to relationships. It doesn't replace family, and it doesn't replace your friends, but it brings something to life that we've lost. It was natural in human habitation, in the village, in the church. You didn't have to like Mrs. Smith to show up with chicken soup when she was sick.

L. Pfeffer: What lessons have you learned working as a cohousing development consultant? What do you do differently now than early in your career? Has there been an evolution in how you see the process?

K. McCamant: I have a renewed and ongoing sense of the strength of the process; the community has a healthy process for how to share ideas, how to listen to each other, how to debate issues, and how to say, "No, this is not working for me." I've learned that acknowledging the community process dovetails with my ability to market a project. Community process, marketing, and membership are directly related. Having a healthy process and a strong community lead directly to a financially strong project. You could have a great financial deal, but if you don't have a healthy group and process, it won't work out. And, at the same time, if you have a healthy process and a tight group, you can get over many hurdles.

L. Pfeffer: What are some of the determining characteristics of a healthy, strong group?

K. McCamant: Strong, healthy groups have members who make decisions efficiently without endless meetings. They trust each other and don't have to question everything. They appreciate the work someone in the group did and are grateful not to have to think through the issues themselves. Trusting means accepting a 
decision someone makes without feeling the need to sit in on countless committee meetings.

When group members learn to trust each other, they don't have to be involved in everything. They can focus their time and expertise on one piece and trust that other people are covering other pieces. In any working situation, I'll accomplish more if while I'm doing my piece I know that all the community members are also doing their pieces. You've also got to accept that it's not always equal. If you're looking for equality and everybody putting in the same number of hours, you'll never be happy. You need to learn to live with those ups and downs.

\section{Healthy groups also look for the best solution for the community as a whole,} which is not necessarily what's best for each individual group member. Groups must also be willing to listen, be flexible and open to change. One of the great things about living in a community, and one of the great reasons for senior cohousing, is it keeps us flexible. We are quick to get set in our ways, and I don't think that serves us as people.

L. Pfeffer: Yes, cohousing allows people to shift the focus from the "I" to what serves the community. In some Asian countries there is a sense of the collective more so than in Western cultures where we think of ourselves as individuals. Cohousing challenges us to think more as members of a group. That's important.

Finally, if you could speak with a wise being who had all the answers, what question would you ask? In your position, with everything that you've experienced, is there still something that is a question for you?

K. McCamant: Cohousing is not a static thing: communities are evolving and changing; the housing market is evolving and changing; the financial market is evolving and changing. And something that worked for a project 20 years ago is not necessarily feasible today. I think the big issue in the U.S. housing market right now is that new housing is out of reach for a huge portion of middle and moderate-income families, and I don't have a solution for that. 
L. Pfeffer: That's still an open-ended question.

\section{K. McCamant: I know these budgets better than anyone, and I can't figure out how to make it cheaper without subsidies.}

It's always interesting as new generations come in. We're just starting to see the top end of the millennial market showing up in the housing market in general, but also in cohousing. All of a sudden, cohousing is seen as this old-fashioned thing by this new generation. I was just on a panel where I was arguing with this young guy who was excited about the 'baugruppe' approach out of Germany. It looked exactly like cohousing to me; I couldn't see any difference. But he saw cohousing as community of old hippies. I was 28 when the book came out: it's 30 years later, and now I'm the old lady.

\section{Baugruppen has an interesting financing model that I'd like to learn about. It} started in Berlin when the wall came down and there were many parcels of land in the middle of town that were empty. The basic concept, as I understand it, is a financing mechanism whereby if you got a number of people together and put together a professional team, you could purchase properties owned by the city. If a group came in with 15 or 20 households committed to investing a certain amount of money, there is financial support from the government. I would love to see something like that in the United States.

L. Pfeffer: Thank you so much for your time Katie. 


\section{Interview with Ronaye Matthew}

Founder and Principal of Cohousing Development Consulting (CDC), Burnaby, BC.

Founding member of Canadian Cohousing Network

Interview conducted on October 24, 2017 (length 1:13:10)

Lynn Pfeffer: What do you see as the most important hurdles for groups wanting to create cohousing, and senior cohousing, in particular? I'm looking for an overview of major headings; we can get into more detail as we go through the interview.

Ronaye Matthew: The lack of professional support.

Lynn Pfeffer: Having just gone through this process here in Ottawa with Convivium Cohousing, I couldn't agree with you more. That's definitely been the biggest hurdle.

Ronaye Matthew: It is something that I feel badly about because people contact me once, or twice a week, wanting support. I'm doing four projects right now, and the only reason I'm doing that many is because I would like to support more cohousing to happen. It's really more than I'd like to be doing.

If there was a way of finding people who have the background to do this work and supporting them with the information they need to transition from conventional development to cohousing development. It's not a huge leap; it requires some capacities that are not necessarily there in conventional developers. What is needed is someone who really understands the development process.

Lynn Pfeffer: Regarding your statement around, "finding people who have the right kind of background to transition into this". What kind of background is required to become a cohousing development consultant.

Ronaye Matthew: Basically, a developer. Someone who understands what it takes to get a project on the ground. That's the big missing piece. They can always hire facilitators to do the community-building aspect, because that's an important piece as well.

The piece that's really missing is people who have the capacity to help manage the development from a legal and financial perspective, so that it's economically viable, and grounded in the reality of the current circumstances, as well as attempting to bring as much affordability within the current context. 
People developing projects in the conventional way are the ones that have the most information about how to do this. Cohousing needs to tap into that, to bring it into the mainstream.

Lynn Pfeffer: Convivium is up against this. We are not experts in the development field. We started from 'ground zero' to build expertise in that area. It's not an easy process.

In an interview that you gave in 2008 you stated - that the development process of a cohousing project is very challenging. Has anything changed in the last ten years, since that interview, that has allowed cohousing projects in British Columbia, to be more successful, now? Can you speculate as to why more projects are actually getting built out West than may have been in 2008 ?

Ronaye Matthew: It's not any easier, actually, it's more difficult. The layers of bureaucracy are even greater than they were ten years ago. I'll use as an example of one of the things that you need to prepare in the development process - a disclosure statement. On the project I managed for Quayside Village in 1996, the disclosure statement was 25 pages long.

The last disclosure statement I prepared, I think it was for Belterra, was 300 pages. That's an indication of the level of bureaucracy. We're living in an over-complexified environment where there are more layers and challenges in development than there were ten, fifteen, twenty years ago.

I think the reason there's more development happening in B.C. is because there's more knowledge about how to make projects happen. There are enough completed cohousing communities here that people can look and say, "Okay, this isn't some crazy thing."

There is a lot of support among the bureaucracies to make it happen; there's a desire to support what cohousing wants to achieve. Government actually wants community, they want affordability, they want the things that cohousing can provide. They just don't know how. If they see a group with capacity, in my experience, the bureaucracy does what it can to support the project.

Lynn Pfeffer: In Vancouver, or in other cases, what have they done to support cohousing?

Ronaye Matthew: For one group that did not use professional project management services, the local jurisdictional authority overlooked the lack of professionalism, and supported the group to secure their development permits. At the end of the day, the group paid more 
than they would have if they'd had professional project management because of the mistakes they made due to lack of knowledge; but they succeeded.

It's rare for groups to succeed on their own, because developing a multi-family residential project is extremely complex and challenging, involving many aspects (legal, financial, jurisdictional, organizational). The group succeeded because of the tenacity and capacity of the individuals involved, along with a certain amount of good luck and good will. It takes a high degree of capacity to understand the complexity.

If you don't have anyone on the team who understands the development process, then basically, whoever is the founding member - the burning soul-needs to be someone who has the 'right type' of intelligence. The person needs to be a concrete thinker, someone who can respond to the needs of the bureaucracy and the larger financial and legal challenges, to be able to put it all together. It's challenging for a group to do this on their own.

Ideally, what we need are more trained professionals who can support groups, because there's a demand for it. There are professionals out there who could learn how to do this. One way to move forward would be if the university offered a course on how to support cohousing groups to make a project happen.

I think some technological institutes have courses on how to become a developer; so this would be how to become a cohousing developer. Maybe it's not a university, maybe it's a technical school. It's not rocket science. If you understand the principles it can be a stepby-step process; you follow the pattern while understanding the complications that are associated with any development process.

Lynn Pfeffer: I am thinking of a possible step forward. Last year someone gave a three-week course at St. Paul University on passive-house design. An expert in cohousing, like you, could come to Ottawa and offer a summer course in a post-secondary school. It would require somebody who is a development professional, like you. I wonder if there's an opportunity for that?

Ronaye Matthew: I see that as being a real possibility-I've actually offered that to people trying to make projects happen in Eastern Canada. I would be willing to teach professionals who I thought had the capacity to take the information and do something with it. 
This isn't something that you would want to offer to anybody who thinks they want to be a developer; there are so many pitfalls in the development process that you want to be careful. I don't want to give someone a noose to hang themselves with.

Lynn Pfeffer: It would be wonderful if we could find a few people with the 'right kind' of intelligence who were willing to go to you, or you to them, or however you envision it, to train. It would be an excellent way for Eastern Canada to have access to the kind of expertise to succeed in these projects. In the Ottawa area, four have fallen through in the last year and a half.

Ronaye Matthew: There have been a number of groups attempting to make things happen in Toronto, Prince Edward Island, Nova Scotia and New Brunswick. Then there's Québec. Québec has managed to create their own way of doing this.

So, why is it that projects don't succeed? There's something missing in whoever is leading, in their capacity to respond to the environment in a way that will support making it happen. Not that they're to blame for it, but there's missing knowledge, or circumstance, or context, or something that is not working.

Lynn Pfeffer: Somebody has to have a vast scope of knowledge; it's unlikely that any one person in the group will have that. Somebody in the group may understand 'this' or 'that' segment, but certainly not all of it. Every step of the way one has to find out: who do we talk to, what's necessary, what's this process, what are we going to have to do? It's painstakingly slow. One person trying to do it all doesn't work.

Do you know why in Québec it's been different?

Ronaye Matthew: No, I don't really. I met one of the founding members of the project in Quebec City years ago, at a cohousing conference; he has since passed away. He was passionate and was able to bring the right people together. He was the 'burning soul', and with his emotional intelligence in that environment, he was able to make it happen.

Lynn Pfeffer: Someone here was trying to start a project on the Gatineau side. She implied that the municipal government had ways of supporting them, which we didn't have in Ottawa. I don't know if that's true, or not, but it may have been the case for Québec City. Québec tends to be more progressive than Ontario. I need to ask these questions there. 
Cohousing is unique in that it is initiated by private citizens taking responsibility for their own housing and lifestyle choices; this is distinct from conventional housing where people buy into the housing market - condos or housing that has been designed with the 'no-name' buyer in mind. In your opinion does this add to the challenges facing a group trying to create a cohousing project? Does the conventional model of developer housing work against the cohousing initiative?

Ronaye Matthew: $\quad$ No, I don't think it works against it. Cohousing is a completely separate type of initiative; both are not in contradiction with each other. The place where it gets challenging for cohousing groups is competing with developers to find land. That's a real challenge. Without land you can't make a cohousing project happen.

For example, I have a project that I'm managing right now. We were in competition with other developers for purchasing the property and had to have the financial capacity to be able to purchase 6 million dollars-worth of land. The group needed a level of organization and capacity to make that happen. It took time to build the group's capacity in that way. There needs to be members who have financial capacity in any urban environment.

I believe that there's value in having economic diversity in a group. All the developments I've been involved with, have had a diversity of needs - people who are in need of affordable accommodation and others who don't need the affordability. Those that don't, are choosing cohousing because of the community aspects, and they are the ones that have the financial capacity.

The financial structure needs to be set up in a way that not only attracts money, but for people to feel secure that they're not going to lose the money they're investing

This is similar to your question about financial institutions.

I don't think there's anything about cohousing being a feminine-driven movement that makes it less attractive to financial institutions. The financial institutions that I work with tell me that they will take any project that I'm involved with because it's about how it's organized, and how much risk there is for the financial institution. They're looking at the management, what the financial structure is, and what is the likelihood of losing money for their shareholders. 
Lynn Pfeffer: Your previous success works in your favour when you approach a financial institution they can say, "This person has been able to develop these other projects and they've been successful." When a cohousing group without previous project experience approaches a financial institution, that's high risk for them.

Ronaye Matthew: It's also how you ask the question. You need to know what information the institution needs in order to make their decision. Whoever is making the ask, needs to ask in a wav that the financial institution can understand.

The financial institutions that I work with now, realize that cohousing is actually less risky than conventional development because your purchasers are involved in the development process. You're not trying to find that 'no-name' person to buy your unit at the end of the day. Your units are already sold to the people who are part of the development.

The members are invested in the project in a way that makes it less risky, regardless of the market conditions. Even if the market drops, someone who's invested in living in a cohousing community is going to follow through on their commitment because they want to make it happen. So, it's partly how information is presented to the financial institution, to understand what they're thinking, so that they understand and think "I don't only want to invest in this one, I'm going to invest in every single one of these that ever happens." I've had financial institutions say, "Do you have any more of these? When's the next one?"

Lynn Pfeffer: Are there financial institutions in BC that are behind this kind of development?

Ronaye Matthew: For sure there are. There's a credit union that I work with in B.C., VanCity Savings, they're amazing. They are so socially progressive. Cohousing fits in so completely with their values that if a project looks viable, they put us in as a priority.

I prefer to work with credit unions because our values are similar, but banks will finance cohousing if the information is presented to them in a way that they understand. I've had banks provide me with letters of interest. I don't think it has to do with any particular bank, it's more about how the information is prepared. I think any bank would finance cohousing is if they understood what it was. And if the person who prepared and presented the information understood what it was that the bank needed to see in order to analyze their risks. 
Lynn Pfeffer: That's a perfect example of how important it is to have someone who understands what it takes. If a group was approaching this without any understanding of what the banks wanted to hear, who could help them understand? Would they speak to somebody in a bank to find out what they needed to hear? How would one go about this?

Ronaye Matthew: They need to work with somebody who understands how to get development financing; a developer is someone who understands how to get development financing together. It's really all about the knowledge base and going back to the very first question about needing a professional, needing someone who understands what it takes.

Lynn Pfeffer: And as far as you know, are there any cohousing development consultants out east?

Ronaye Matthew: There's no one that I'm aware of. I know that there was a group in Toronto that worked with a non-profit development consultant for a while, but they weren't successful. There are not many people in North America who actually know how to do this, period. That's the fact of it.

Lynn Pfeffer: I am going to consider the idea of organizing some kind of a course out here.

Ronaye Matthew: I definitely would be willing to do that. I'm looking at how to leave behind information that will support this movement to continue. I believe there's value to it, more than just the housing form. It supports humans to learn collaboration, to get back to our original tribal roots of working together.

Lynn Pfeffer: I couldn't agree more! We are like grapes shrivelling on the vine right now; we don't have the social and interpersonal juice that feeds us as human beings. We need that interaction for creativity; we need that for growth; we need that for health. I think isolation is working against our evolution as human beings.

Ronaye Matthew: I I agree. I see that with groups that I've been involved with and stay in touch with. There's an evolution of consciousness that results when people move into cohousing. There's learning and growth and increased capacity.

That it is one of the things that we need to find a way to continue. Before I leave the planet, I would like to find ways to support cohousing to carry on. I think one way of doing that is through education; I don't have the time, or capacity to set that up, but if somebody said, "Okay, what about doing a three-week course in Ottawa, for example, 
and we'll organize all of the registration, location, etc." I definitely would be interested in giving a training.

Lynn Pfeffer: I think that would be extremely valuable.

Ronaye Matthew: It's about finding ways to generate the level of knowledge that will support people to successfully facilitate these kinds of programs.

I know this isn't the question that you asked, but it's one that's up for me, I think it's a woman's movement; women are leading this. In my experience, the founding members of most cohousing projects have been either single women, or women couples, or where there's a male and a female involved, it's the woman who has been the leading influence.

In my experience, this movement is supported when there is the level of knowledge and understanding about how to do that within the current paradigm that we're in. Do you understand what I mean?

So, rather than asking for something from anyone, what the cohousing movement needs to do is say, this is good for you, you want this, this is low-risk, and this is valuable. As soon as people understand that message, it's supported-by the men as well.

Lynn Pfeffer: It sounds like you're saying that the leaders of the cohousing movement are women, and that there is a way to work within the existing paradigm to get the support that we require to be successful in these projects. That's an interesting point.

I want to go back to something you mentioned earlier, that in all the projects you've developed, there's been a diversity of economic need.

Many cohousing groups begin with a group of people that have diverse affordability needs. But many of the lower income members drop away as they realize that they cannot afford to buy a unit. Other members may have the desire to help, but don't have the capacity to buy a second unit to rent.

How have the projects that you have worked on been able to accommodate different levels of income?

Ronaye Matthew: There are different ways. 
For a group wanting to build a project in central Ottawa needing a site big enough for an apartment-style building, do you know how much the land would cost?

Lynn Pfeffer: I think you are looking at \$2.5 million for a site that could accommodate 20-25 units.

Ronaye Matthew: In Vancouver, the land cost for something like that is about \$6 million.

One of the ways of creating affordability with high land costs, is to get agreement to build a higher density than what normally would have been possible for a conventional market development. Typically, in my experience, municipalities are supportive of this.

Then you don't include the land cost in the value of the units that are constructed in addition to the density that normally would have been possible. For example, if 25 units was originally mandated for the $\$ 2.5$ million property, but you built 30 units, you could have 5 units that had no land cost associated with them. Those units are \$100,000 less than the market units, and then you put covenants in place to secure those units as nonmarket for perpetuity.

When you're dealing with high land costs, that is one way of doing it where there's a zero cost to the developer and where the purchasers of the market units are not having to pay anything extra. All they're doing is putting up with more density on their property than what they would've had in other circumstances.

That is one way of creating the non-market component. Part of this depends on the appetite of the local political environment for creating non-marketing housing, and whether they have a vehicle for providing that. It's called a density bonus. It can be an effective way of supporting diversity.

Lynn Pfeffer: Does that require a rezoning application?

Ronaye Matthew: Yes. This is why a development consultant that understands these things is so essential - this is all part of the negotiation with the jurisdiction you're deal with to get the rezoning.

Firstly, you want to choose a site that has the capacity for the type of zoning that you need for the project that you're doing. Then it's a matter of looking the edges? What else is possible? Usually, in our current context, most cities are attempting to find ways to create affordable housing. 
When you have non-market units as part of a market cohousing development, the cohousing group can manage the resale of those over time. There are examples of groups doing that, whereas you can't impose that on a conventional strata model. A conventional developer can't say, "you manage these non-market units going forward." That's not going to happen.

Whereas a cohousing group, as the developer of the project, can commit to these longerterm commitments and say, "Yes, we will manage these." There are protocols needed to ensure that the non-market units remain at whatever percentage below market value that they started at.

There are different ways of doing that, but you need an entity to manage that. If the jurisdictional agency that you're working with doesn't have an affordable housing department, then they don't have a way to maintain affordable housing over time; the only way they can is through requiring rentals.

Lynn Pfeffer: In Ottawa, there is support for affordable housing development in rental projects. But there aren't mechanisms whereby you can build non-market units within a market development unless you agree to having those units on the subsidized housing list.

The affordable housing registry in Ottawa has long wait lists; if you create below-market housing you have to take people off that list. Communities then loose control over selecting those who want to take part in a cohousing lifestyle.

Ronaye Matthew: That's always a challenge; how to create a self-selection process that actually works for the cohousing group. In cohousing, when you're reselling units after the development is completed, you have no control over who buys in.

Lynn Pfeffer: That is if the cohousing project is a strata title (condo), correct?

Ronaye Matthew: That's right. The non-market units are no different. What we do for re-sales is make sure there's an education process where people understand what they're buying into, and then we trust that whoever buys in is the right person, and we're going to find a way to make it work.

When you're dealing with affordability there's an added challenge because some people, that's all they're looking for - affordable housing - period. They don't actually care about community. What needs to be negotiated with the municipal jurisdiction, is 
how much control the cohousing group can have over who buys in and maybe adding the requirement that they take part in a cohousing education process.

That's part of what you negotiate during the development phase with the local jurisdiction. You need to be clear on what your goals are. You need to be aware of the implications of what you're asking for and attempt to come to agreement with the jurisdiction about what you're willing to provide.

That's also part of why you need local development consultants who understand the local conditions, local context, and what is possible, what things need to be negotiated, or what kind of bylaws need to be put in place to support the project.

Lynn Pfeffer: The group I am a member of, Convivium Cohousing, is creating an equity cohousing cooperative rather than a condo structure. Are you aware of other projects that have used the co-op structure?

Ronaye Matthew: I don't recommend that groups set up as a co-operative because we're not in a legal and financial paradigm that supports that. I don't know if there are new cooperatives in the east, but there aren't any in the west. They stopped happening when CMHC withdrew the funding back in the 1980's.

I'm just going to say it straight out - it needs a 'big daddy' to be able to finance them. Conventional financial institutions are not going to finance them; as much as anything this is the reason we use the strata title. There's no benefit to a co-op, none.

Lynn Pfeffer: Other than having control over the units when they're turning over?

Ronaye Matthew: That's true, that is a benefit. I support groups to believe that the chaos theory is actually a better way to go. As long as we define ourselves clearly around what is important to us as a cohousing community, I believe that we will attract the people that are appropriate. Living in cohousing is about learning to collaborate, and sometimes we get people who we think are really difficult. But learning how to collaborate, work together, and deal with differences is part of what cohousing is about.

Lynn Pfeffer: It's part of learning of how to communicate.

Ronaye Matthew: Exactly, and if they're 'difficult' it's because we haven't found a way to integrate them into the process in a way that serves the larger collective. It's all grist for the mill, there's always opportunity here. In my experience it actually works. 
I chose to live at Cranberry Commons not particularly because I was interested in cohousing, but because I was interested in environmental sustainability. I found cohousing scary - the idea of being in contact with people; I didn't choose it for the same reason that many do - the social contact. I'm an extreme introvert. Cohousing helps to make sure that I'm not as flat-sided. We had some challenges in our community in the early days.

It's easy to point to a couple of members and say, "they're the problem," but it forced us to learn how to set boundaries, how to define ourselves. The process of working things through supported us as a community to become more mature and to grow in ways that we would not have otherwise.

Lynn Pfeffer: Are you aware that the Federal Government is currently working on a five-year National Housing Strategy?

Ronaye Matthew: $\quad$ No, I tend to not be very political.

Lynn Pfeffer: What do you think should be included in a national housing strategy to benefit seniors trying to develop innovative housing projects?

Ronaye Matthew: What we really need are more professionals that can support groups to make it happen. Whatever it is that the government could do to support that is what we need. Little grants here and there are not going to help. What is needed is someone who knows how to put it all together, with whatever it is that's there-how to make the mud pie.

Lynn Pfeffer: Something that has been suggested is that government could give a grant or loan to organizations so that they could take a training to learn about the process.

Ronaye Matthew: Yeah, but it's not the group that needs to be trained.

Lynn Pfeffer: Is this more about training development consultants?

Ronaye Matthew: Exactly. When I do a workshop with groups, one of the first steps is to give them an overview and to emphasize that they cannot do it themselves, that actually, it's not possible, unless they have people in the group who have development skills.

Lynn Pfeffer: Given that groups in eastern Canada have limited access to cohousing development consultants, what suggestions would you have for them? 
Ronaye Matthew: $\quad$ *To see if you can find development consultants locally that would be interested in learning about how to do cohousing development. Talk to local developers who are successful - not just those in the non-profit world, those in the for-profit too - tell them about cohousing and say, "here's an opportunity for you to branch out" and "here's something you could include in your project - the social sustainability aspect."

Developers, if they understood the potential, might be able to take a segment of their larger-scale developments and set it aside for cohousing, and support the group to be successful because they have the knowledge. For example, getting the development approvals. They could do the heavy lifting.

Lynn Pfeffer: Early on, Convivium was in discussion with a developer here in Ottawa. The developer was creating an entire 'village' on a large piece of land, with a community hub, medical clinic and parks; it would have been a good fit. We couldn't get them to 'buy in' to the idea.

Ronaye Matthew: That's the challenge. It ends up being a question of needing somebody as an intermediary. There are architects on the East Coast - Kraus-Fitch is one that does cohousing. It may be that you find another kind of knowledgeable advocate, not necessarily a development consultant.

Lynn Pfeffer: Do you know where Kraus-Fitch is based?

Ronaye Matthew: They are on the East Coast somewhere. I think they were the firm that supported 'Habitat Québec' in the early stages. It might be a matter of looking at resources that are available on the East Coast of the US because there are more resources in the US than there are in Canada. There is a certain amount of knowledge that an architect has about project management that can be valuable. I know Katie McCamant is a development consultant; I don't know how busy she is right now.

Lynn Pfeffer: She is very busy, just like you. She's also on a mission to see 500 cohousing projects built over the next five to ten-years in the US alone. The idea is not for her to develop all the projects herself, but rather that the people she trains operate as satellites developing projects around the US. She trains the cohousing developers and then they go off and do two or three projects.

Ronaye Matthew: So, she has a similar approach where she's attempting to train professionals to support the movement. 
Lynn Pfeffer: The idea runs parallel to yours, in that what is required is more training at the level of the development consultant.

Have you considered what changes to public policy might help - at the municipal, provincial or federal level? Is there anything in terms of the policy side that would support cohousing?

Ronaye Matthew: I find that policy in B.C. does support cohousing. I'm not familiar with how it is in other provinces.

It's essentially about looking at the local Official Community Plan, wherever density is supported, cohousing could be supported. It's a matter of working with them. One of the ways it can be supported - this is a detail - is for the city to not include the common amenity areas in your floor-space ratio calculation.

In my experience, that's an easy thing for bureaucracies to go along with because they see the social benefits of that. It's challenging for bureaucracies to give special accommodations to one developer over another, because really, a cohousing group is also a developer, and the bureaucracy and politicians need to justify their support based on the same parameters that they would use with a conventional developer.

When you're creating a development for yourself to live in, you will benefit from what it is that you've created, so strictly speaking, it's not a non-profit.

Lynn Pfeffer: How is cohousing supported in Vancouver?

Ronaye Matthew: When we go in to the planning department they do everything, within the parameters they can control, to help us get through the process. I would say that's the reason the group in Vancouver was successful; the City of Vancouver, the planning department, wanted to see a cohousing project happen.

Lynn Pfeffer: It sounds like the city planning department is one place to make connections and lobby for this.

Ronaye Matthew: Essentially, the planning department can't really do much until you bring in a development proposal - so it's really not until you have a potential site. I'm going to use the North Vancouver example. We kept finding sites and would go in to (the City) and say, "Well what about this one? Can we do this?" They were trying to make it work for us and give us ideas and direction. In that process we gained knowledge about what was 
possible in that particular jurisdiction. They are there to support you, to make a project happen. It's a matter of knowing how to use them as a resource.

Lynn Pfeffer: Given the breadth of experience that you now have - if you were to ask a question of somebody who knew even more than you, what would you ask? What are some of your remaining questions?

Ronaye Matthew: It's always how to make this easier, and I don't know if there's a way. I would say that one of the things I've learned over the years is how to streamline (the process). There are consistent things that happen and need to be dealt with that are part of the process. If there was someone who knew more about that than me, then that would be my question: how do we make this easier?

Lynn Pfeffer: If you asked that same question of yourself now, seeing where you were five years ago, what are some of the things that have made it easier?

Ronaye Matthew: I have a deeper understanding of how the group process actually works, the flow of it, and where it makes sense to allow the group to expand into more chaos, and where it makes sense to constrain and contain.

In the early days, I was trying to contain as much as possible. There ended up being a certain resistance to that. Groups don't want to be contained; they want to be able to expand to the limits of their creativity.

Part of the role of the development consultant is to actually create the safe container within which the creative process can occur. I would say that my container has gotten larger and I've realized that there's actually more room for chaos in it, and that chaos actually contributes to the creative process and the learning. People getting into conflict with each other and having that come up into the larger group, getting it cleared and dealt with, is part of the learning that is an important part of what supports the evolution of the group, the bonding of the group and really the consciousness of the group.

Messes are okay, as long as there is not such a big mess that the group is no longer safe. Finding that fine line of safety, and yet having the capacity for expansion.

Lynn Pfeffer: That's fascinating. It sounds like too much control doesn't allow the process to unfold, and that there needs to be a confidence that chaos and conflict can be part of the creative process. 
Ronaye Matthew: It's definitely a fine line, a balancing (act). It's a dance, and for creativity to flourish there needs to be a certain amount of chaos.

Lynn Pfeffer: Last year one of your associates, Margaret Critchlow, came to give Convivium a workshop on facilitation - she's coming again in two weeks. With her facilitation and her presence, members expressed more. People came forward with their issues, and in working them through, actually felt closer. It doesn't seem as easy to do on our own.

Ronaye Matthew: I actually think that it (facilitation) is something that requires an outsider. Even with the level of sophistication and knowledge that I have about cohousing, I would never dream of trying to facilitate a community-building process of any magnitude in my own cohousing community.

Having an outsider supports the safety, the creation of the container, in a way that is not possible with members attempting to do it themselves. I'm not sure why that is.

Lynn Pfeffer: I'm grateful to have met you. I'm very serious about getting you here to teach. One question would be how to recruit the people you think would benefit from this and want to take it on.

Ronaye Matthew: If you decide that you want to focus on this, I would definitely be happy to support you with giving you a list of qualifications of the type of people that I think would be able to learn about this, and then create in a meaningful way. Some of the places to recruit participants, off the top of my head, might be the School of Architecture and the City Planning Department. People who are in city planning are learning many of the skills needed for the development process. 


\section{Interview with David Kardish}

Vice-President of Land Development, The Regional Group, Ottawa.

Board Member of Cahdco (Development arm of CCOC)

Interview conducted on November 21, 2017 (length 1:09:55)

NB: This interview was conducted to gather information for the use of Convivium Cohousing for Seniors as a case study. Convivium had been in discussions with Regional in 2016 regarding the potential of a turnkey project within the Greystone Development in Ottawa. It was not possible to reach agreement, and the project never materialized. This discussion illuminates some of the issues a cohousing group might want to consider in their negotiations with a housing developer. The interview underscores the cultural differences between the real-estate development world and the cohousing group, and the advantages of the group hiring a professional representative for these negotiations.

David Kardish: The biggest problem for Regional was that there was no consensus for what Convivium wanted in the building. They wanted an energy-efficient LEED building, but were not ready to commit to paying for it. They needed to make an up-front investment and have some understanding of the increase in costs associated with those upgrades.

I felt your group wanted us to develop all the options with all the variables and give you a "menu" that you could choose from. In doing so, you also wanted us to absorb all the costs associated with that; that's a very expensive proposition. You have to pre-design a building and have some very broad understanding of what the incremental costs are. I think that's where the project fell down.

Subsequent to that you went to Cahdco - I think that was a good move on your part. Cahdco understands multi-unit development and could help frame what the group wanted and assist with putting some numbers to those options. CCOC has the experience; Cahdco is on the development and consulting side of things. Social agencies make contact with Cahdco when they want to build housing, for example, the Multifaith Housing Group for the Anglican Church.

At one time Cahdco only developed long-term, affordable housing. They did one project in the market and the model they were using didn't work. So, they started 
this consulting arm. It's a good group for you because they understand the building side of all this.

This is the same as Convivium hiring a design/build team, except that Cahdco is focused on social housing. A design/build team may be more profit-oriented. Cahdco built Beaver Barracks, an attractive affordable housing project comparable to what would be expected by a cohousing group.

Lynn Pfeffer: What has been your role in Regional and the Greystone project?

David Kardish: I buy land, get the land approvals in place, and sub-divide the land. I was the lead at Regional in putting this aspect of the Greystone Project together. It starts with bidding on the land, then negotiations, planning, and now development. I and my team were responsible for the acquisition, meeting with Old Ottawa East Community Association, getting approvals from the City, and moving the whole project forward. My role in these areas of the Greystone project is almost over.

The land went to tender, and we were the top bidders. We assured the Fathers we would close, and we ended up with the land. It's a beautiful asset in a beautiful part of the City. Now we will turn the land over to our housing group; you met Dave Wallace. My son Josh is now heading up the housing group; this is the EQ side of things.

We're also responsible for the disposition of certain parts of it that we don't necessarily want to develop. I am in negotiations with CCOC/ Cahdco for them to acquire the Deschatelets Building and put it to some municipal uses as well as affordable housing and health uses. I sold almost an acre of land to the Lemay Construction Group for building an assisted-living senior's residence. We tend not to get involved with things that aren't in our strategic plan, like senior housing.

\section{Lynn Pfeffer: Why would a developer be hesitant to sell land to a non-profit group versus someone like Lemay, a proven developer of senior residences?}


David Kardish: I don't think developers are hesitant; for example, one of the goals we had when we did Greystone was to try to facilitate the development of non-profit housing, or affordable housing. We didn't want this to be an exclusive enclave of million- dollar homes. It was always my objective to achieve and assist that by providing half-a-million dollars to whatever group was going to build it. So, that's where we're at now with CCOC. We want to bring some affordable housing to the site, because that allows us to fill our objective of having a mixed income community, and that was one of the reasons why I was looking at seeing if we could do something with Convivium as well.

Lynn Pfeffer: CCOC has a long track-record, so you're not taking a huge risk to work with CCOC to build affordable housing; it's more of a risk to work with groups that don't have previous projects and will never have another project.

David Kardish: It's all a question of how much time and energy you want to put toward this. I have a comfort level with CCOC that I may not with somebody else. So, if I can choose someone I have a comfort level with, that's the way I'll go. My time is valuable, and there's only a certain level of risk that I want to take.

Lynn Pfeffer: If a cohousing group wanted to get a project built, using a developer, like you, to do a turnkey, what would they have to do in order for you to say, "This is worth my time and risk"?

David Kardish: They would have to know what they want, so we don't spend months trying to figure that out. They would need a financial plan that makes sense both to me and the financial institutions. I felt this issue was going to cause problems eventually. With an equity co-op, as opposed to a condo, we are always concerned with how it will get funded in the end.

Lynn Pfeffer: Meaning that the condo model is more familiar to financial institutions?

David Kardish: Exactly. 
Lynn Pfeffer: Who might help a group develop a financial plan that would make sense to a developer when the group doesn't have that expertise?

David Kardish: They can hire an appraiser, and there are people who do financial modeling. CBRE and Altas are consulting companies who can develop a plan that would give the developer some confidence that they're not wasting their time. I hate wasting my time. I'm very good at what I do, and I know when I have a deal that I can make work. I don't bother chasing a million other things that don't worksome people chase everything under the sun - I don't do that.

Lynn Pfeffer: I think that's a skill, to be able to sift out what is worth putting your time into.

David Kardish: That's exactly it. You need the ability to discern viability quickly. Going down the road with Convivium was a bit different than the model I usually take because I have a long relationship with Lynne, we worked together years ago, and I have a development background. I was the first housing coordinator for the old Regional Municipality of Ottawa Carleton, so I was instrumental in getting municipal non-profits off the ground in different municipalities in Ottawa, but that's a long time ago.

Lynn Pfeffer: Is that still something you remain interested in?

David Kardish: Yes. I am now on the board of Cahdco who pursue these things, and that's an interest I still have. As I said, from day one, we wanted to have a mixed income community out there.

Lynn Pfeffer: What's your contribution as a board member of Cahdco?

David Kardish: I think we bring the perspective of the private developer to the board. For example, Cahdco recently looked for a business partner on a piece of land owned by a social agency, I think it was Unitarian House, and they got no responses. Two of us, members from the private sector on the board, met with them and explained that they didn't get much interest because developers were too busy to get involved in this kind of thing This has probably been the best 
year in 10 years for housing starts in Ottawa, so developers put their attention to what they need to do, rather than chase something that may not happen.

Lynn Pfeffer: In that scenario, what could they do differently?

David Kardish: Before they go to a developer, they should ask someone in the private sector whether it's a good time to get positive responses. They may not be cogniscent of what's happening in the larger market place. Also, before they develop their market analysis of the projects, they should talk to us about what is happening, in, for example, the condo market in terms of what units and sizes of units are selling. Because Cahdco does mixed-use projects, market units, affordable housing units, and we have a much better understanding of the market component, because we are dealing with it all the time.

We talked with Convivium about having a good financial plan and a better understanding of what the group really wants. There didn't seem to be a consensus for what the group wanted in terms of unit sizes, amenities, and building standards, which is difficult for developers to deal with. So, I think you need a more sustainable financial plan that you can sell to the developer. If everybody's asset is going to come from the sale of a house, and all of you are going to have to sell your houses at a certain time, that's problematic from a developer's perspective.

Lynn Pfeffer: Could part of the issue also have been that the opportunity of Greystone came too early in the organization of the group?

David Kardish: That could be very well it...

Lynn Pfeffer: Convivium saw this as a great opportunity and wanted to see if we could make it work, but I don't think we were at the stage where we could offer Regional everything they needed to feel confident.

David Kardish: You may be right. Maybe now that you've thought about some of the issues I've raised, it will be much easier in the future to deal with a developer or your 
consultants. It may have been rushed. This was almost 2 years ago, now. I think that's a good observation.

Lynn Pfeffer: Convivium felt that hiring Jamey Burr was useful. Did Regional find it useful to deal with a hired consultant?

David Kardish: Yes, but our time with dealing with Jamey was limited. One moment we were getting somewhere, and the next thing we knew he was gone, and you had hired Dennis. My impression was that we were seeming to get some answers, then you shifted consultants, and then you were going out for proposals from developers. We decided we had spent enough time and effort, but it wasn't us that killed it.

Lynn Pfeffer: In your opinion what 'killed' it?

David Kardish: We couldn't get a commitment from you. The next thing we knew, you were looking at other sites. That's the impression we got. It seemed like we were making some progress... anyway it's water under the bridge.

Regional felt with our commitment to half-a-million dollars to social housing we were reaching out. Convivium was more my project, because I wanted to see whether we could make it work for all of you, and I had to convince a few of the people here at Regional to participate. Then at some point the other group got frustrated, and we had authorized 10-15,000 dollars to assist and nothing came of it. The feeling was, at that point, that if we wanted to move forward, Convivium would have to have some skin in the game.

You need to have 10, 15, 20,000 dollars if you want us to look at all these options for you. That was never forthcoming, so we felt that if you weren't prepared to put money in the game, that we weren't sure how viable your group was going to be. 
Lynn Pfeffer: It sounds like you wanted to help, that you hoped it would happen, and that you tried to bring other people along. Of course, other people who aren't as committed to the project aren't going to be as willing to put up with uncertainty.

I'd like to explain more fully why Convivium wasn't able to move forward, apart from it being too early in the process. We were excited about the site to the south of Deschatelets, Orchard Flats. But we thought the building was too big for us to manage with $50+$ units.

David Kardish: I had offered you the site to the North of the Deschatelets building that was suitable for about 25 units, and I was told it was too small.

Lynn Pfeffer: The site was beside the planned high-rise senior residence and the on-grade parking for the proposed community Hub. Many of us felt that we would be enclosed by parking, and that the shadows from the Deschatelets building would interfere with our access to sunlight.

David Kardish: Yet this is urban living, and wherever you buy a piece of land in downtown Ottawa, you are going to have those issues and more.

Lynn Pfeffer: I think that's important for us to be aware of because most of us have been living in houses in quieter residential areas.

David Kardish: Exactly. I found the group to be idealistic and unrealistic.

Lynn Pfeffer: It would seem that if we are going to be successful in getting this built, we will have to be more realistic and less idealistic.

David Kardish: I think so.

Lynn Pfeffer: Regarding the site to the south of Deschatelets, when Convivium communicated that it was too large for our community, you proposed splitting the building in half and offering Convivium one side. Many of us felt that the half 'up for offer' lacked access to light because of the higher townhouses to the east, and the 
shared fire wall with the townhouses to the west. Had you offered us the other half where you proposed the townhouses, I think would have jumped at it because of the orientation.

David Kardish: That ended up being an exercise that didn't work for us either.

We have now taken that block and cut it back so it's much smaller. We're going to be building about 24 stacked townhouses there and adding the balance of that site to the Riverfront townhouses.

Lynn Pfeffer: How much do stacked town-houses end up costing, per unit?

David Kardish: They are going to go for $\$ 425$ - $\$ 450$ a foot. So, a 1000 sq. ft. unit will cost $\$ 450,000$ and that compares to our concrete condo, the Terraces, which are $\$ 525$-\$550 a foot. That's a medium rise, 9-storey building.

Lynn Pfeffer: If a co-housing group approached a developer and said they could afford this $\$ 425$ - \$450, had a financial plan and could prove it, and wanted to buy 20 of those stacked town houses...

David Kardish: We would have done a deal in a minute. But would they buy it on a condominium basis, or would they want to buy them in bulk and set it up as an equity co-op?

Lynn Pfeffer: That makes a difference?

David Kardish: Selling them on a condo basis is easy. I'm dealing with individuals and I can transfer title to each person as a condo. But if a group wanted to buy all 20 units, there would have to be a sound financial plan with a bank behind them to commit to bridge financing until their houses sold.

Lynn Pfeffer: If a bank were committed to this kind of bridge financing, would a developer still prefer to sell the units as individual condos? 
David Kardish: It would be easier as a condo structure because it's more understandable. I understand an equity co-op, but the co-op structure will make it difficult to get financing. You may get a bank behind you, but it likely wouldn't be one of the major financial institutions.

Lynn Pfeffer: Is Desjardins considered one of the major banks?

David Kardish: They are a secondary one, and I understand that they would consider something like that. The top-tier banks are TD, Bank of Montreal, Bank of Nova Scotia, and CIBC; then you have Desjardins, Laurentian, and National Bank. Then there are even smaller institutions. They are all good; we deal with all of them.

Lynn Pfeffer: It is disappointing that our culture is so much more receptive to the condo structure than the cooperative structure.

David Kardish: Here is one way a cohousing group could do it. For example, we are now doing a 27 unit stacked town-house with units ranging from 800 sq.ft. to 1200 sq.ft. It has its own dedicated parking garage. If a group had, say, 20 households, the group could buy all of the condos and then restructure it as an equity co-op afterwards. That way our risk is all within the condo structure. Then, with $100 \%$ agreement, the group can dispose of the condo structure, and set up an equity co-op. *This approach adds another step, and may cost more, but this could be a way to handle a developer's reluctance to deal with you.

Lynn Pfeffer: That is excellent input. For an agreement like that to work from the cohousing perspective, one or two of those units would need to be turned into a community unit.

David Kardish: That's no problem. Let's say it's a 27 unit project. It could look like this: individual households will buy all 27 units and take individual title of 26, and then we'll all take title to one unit. So, you'll have 27 names on one unit. You'll turn it into a condo, and then afterward you do the co-operative. It's no different for us than selling this to the general market place. We are launching our 
project next spring, so if you all want to buy a condo and turn it into an equity co-op, let me show you what it looks like.

Let me show you the plans. As I said, our thoughts have changed; these are flats and towns. This is on the south side of the Deschatelets building. There are units here and units in the center, all with their own entrances. Parking for 22 cars is underneath. There are four storeys and 27 units, but we are thinking of making it smaller.

Lynn Pfeffer: You refer to flats and towns. What do you consider a town?

David Kardish: Some of the towns are 2 storeys, and some of the flats are just flats: it's a mix. You come around from the back to the garage. These units have terraces. We're going to market with this probably in June or July. If a group came along and said they wanted to buy the whole thing, we'd probably give them a price of $\$ 425$ a foot, but because we don't have to spend marketing dollars, maybe it becomes $\$ 410$ a foot. That was how I was trying to do it before.

Lynn Pfeffer: I want to turn to a broader question about public policy; whose responsibility do you think it is to address the upcoming increase in need for senior housing alternatives? I know you are in private industry, so that already orients you a certain way. But, is there a role for government assistance when considering alternatives to conventional seniors' residences? What might this look like at the policy planning level? If you were to project into the future when $30 \%$ of the population are seniors, and a lot of them are without their families, what could you envision?

David Kardish: Government would likely provide assistance to groups like yours. They could provide seed money to get the group going, maybe $\$ 10-15,000$, and also help with equity. If the assistance is for an equity co-op rather than a condo, CMHC has a lot of money, and they could look at funding the various alternatives. While the initiative has to come from the groups themselves, incentive funding and expert assistance on how to proceed would help. Convivium has spent two years or more trying to move forward. That's a long time. How much further 
ahead would you be if you had somebody with expertise guiding you? If there was a group of policy people working at CMHC with experience in this area, they could make themselves available to groups like yours. I don't imagine that there are lots of groups like yours; maybe at one time there were two groups thinking of doing an equity co-op in Ottawa.

Lynn Pfeffer: There are about 5 groups around Ottawa trying to create cohousing right now; although not equity co-ops.

David Kardish: Okay, I didn't realize that.

Lynn Pfeffer: This also includes across the river, not just Ottawa city: Wakefield, Gatineau, Perth. But there are two, or three, in Ottawa right now. In western Canada, cohousing has really taken off because they have the expertise. A cohousing development consultant in British Columbia has already done ten projects there. She's now working on four simultaneous projects because she has the expertise and the cohousing groups can utilize her experience. Cohousing groups don't have anyone out east, and she can't take on any projects in Central or Eastern Canada because she is too busy.

\section{David Kardish: And when she goes to developers there's a proven track record.}

Lynn Pfeffer: I think your suggestions regarding government support are excellent. Do you have ideas about how cohousing groups could lobby?

David Kardish: They should lobby both the provincial and federal governments. The province has the Ministry of Housing, which has both housing and social objectives. Cohousing groups could indicate that this is a potential alternative for a group of seniors or older adults. They should start with the local MLA, and then move up to the Provincial Level. If there were 20-30 groups, and providing seed money is a onetime effort, that's $\$ 25,000$ dollars, which is not a lot to help them move forward. 
But if I were designing a program like that, I would say the province is going to put 25,000 dollars in, but we want each group to also put \$25,000 in, up

front. Now each group has skin in the game. The seed money and expertise would help, but at some point, you need a commitment from the group.

Lynn Pfeffer: Groups should consider matching the contribution from the government.

David Kardish: That would show real interest.

Lynn Pfeffer: Very good suggestions.

Turning to a different topic. Both the development and the financial sectors are mostly male dominated. Do you think that has any impact on cohousing groups, most of which are led by women?

David Kardish: First of all, developers aren't all men. One of my fellow board members at Cahdco is a vice-president of land development at Minto: she's a woman. Many of the planners in Ottawa are women. Increasingly, more engineers are women. Developers rely on planners, engineers, and building designers, and I am seeing more and more women in this profession every day. We hired Erin O'Connor, from Minto; she's a wonderful addition to my team, and if I can find more Erins, I would be happy to hire them. It's not as male dominated as it used to be. When I started working 43 years ago at the old Regional Municipality of Ottawa Carleton, 90\% of the people there were men. Now, in the Planning Department of the City of Ottawa, I think more than 50\% are women, probably 25-30\% of the engineers are women, and increasingly there are more women in landscape architecture.

Lynn Pfeffer: In the field of architecture, there has been a big change from the time that I was studying at Carleton in the late 1980's, until now. We had maybe 4-5 women in a studio group of 25, and now the majority are women. I think the financial power is still with men though; it's going to take a while for these generations to move up the ladder. 
David Kardish: Yes, the heads of most of the companies are male dominated.

Lynn Pfeffer: And the people with money to invest are probably mostly men. Hopefully things will change so that more women will enter corporate fields.

David Kardish: I think that will be the case in corporations, but family-held businesses are a little different. This is a family-held business, and there aren't many women in it. So, it all depends on the nature of the corporation.

Lynn Pfeffer: This is something that is on my mind a lot: It appears that the lowest income seniors will find accommodation in affordable housing, but, according to a study done on vulnerable seniors by the Council on Aging, only 6\% of Ottawa seniors fall into that category by income level. Ottawa seniors are somewhat wealthier than those in the rest of the country, but even so, that's a lot of seniors who will need accommodation somewhere else.

David Kardish: That doesn't surprise me. Thirty years ago, when I was doing affordable housing, I think it was only about 10\% of the population that qualified for that type of assistance.

Lynn Pfeffer: Or if they qualify for long term-care homes, they may not get in with the long wait lists. The wealthiest will have the option of moving into privately-run residences. Of course, you know the costs of those: $\$ 4000$ - $\$ 6000$ a month is not unusual, which seems like highway robbery. There will be those who spend all of their life savings on such residences, leaving nothing as legacy to their families. Some $70 \%$ of seniors will not be able to afford the cost of private residences and will not qualify for affordable housing. The housing needs of the moderateincome senior have not been addressed. How do you envision addressing their needs?

David Kardish: It's too categorical to say they haven't been addressed. Many moderate-income seniors have houses with equity that they can transfer into a condo or a retirement home. And, as you say, there is a range of retirement homes. My mother-in-law can afford to live in Lord Lansdowne. But others cost $\$ 3500$ - 
4000 a month, as opposed to $\$ 7000$ - $\$ 8000$ a month. You really have to look at the depth of the need of the middle-income senior and what assets they have. It would be very nice if the government would do more, but should they be doing more?

Lynn Pfeffer: I'm thinking less about government subsidies and more about providing alternatives to affordable housing for seniors. The traditional old-age home is not where a lot of baby-boomer seniors want to end up; it's not an appealing model. So, a lot of people stay in their homes because they don't want to move in to an old-age residence: my Mom, her sister, her friend. And it's not healthy or safe for them to be living alone and getting older. Our society isn't addressing this problem. I'm grateful the very poorest seniors are looked after. But there is a whole group of people who are not going want to give their autonomy away and be managed and structured in an old-age residence.

\section{David Kardish: You are making a clear case for the alternatives, but in order to build that sector up, you need to provide the expertise and the incentives to make it happen.}

Lynn Pfeffer: It's only going to happen at a grass-roots level. I'm trying to imagine our culture changing its priorities and somehow supporting this other model for how to age. I don't know how it's going to happen, I just feel like it needs to.

David Kardish: We may be on the cusp of it. As we all age, there is the need for more housing options. I don't think the government has seen it yet. I think the more options you have, the more likely you will be to meet the needs of different groups. Right now, as you say, it looks like it's the private sector, the nursing homes, or people staying in their house. I know that the government has been putting a lot of money, through CCAC's and similar programs, to help people stay in their homes because that is probably the cheapest alternative. But this doesn't deal with the social isolation you talk about. But there are places where seniors can go for social engagement. I was on the Board of Directors of Good Companions, a program designed to get seniors out and mingling with other seniors. 
Lynn Pfeffer: Yes, but when seniors are really old, they don't go out at all. As you were speaking, I was wondering what role developers could play in changing the limited options for seniors. If the government is not going to do it on a policy level, is there any way developers could step in?

David Kardish: I think developers could, but we tend to do the easy thing. As I said before, time and effort are always at stake. For example, we developed this plan, we have to go to market and find 27 people to buy all the units, I'll find those 27 people very quickly, and in two or three months we'll be under construction. If there was a program in place that assisted cohousing groups with planning and financing, developers could be assured that if thev take the cohousing route, they won't waste time and monev and end up with nothing. With such a program, developers may be interested in playing a role. But there also needs to be more structure from the cohousing group, whether on the co-op or equity side.

Lynn Pfeffer: By more structure, do you mean more organization?

David Kardish: Yes. And they need the ability to sell it to the developers. I talked before about lobbying the provincial government. If the Ministry of Housing were lobbied to develop a program to assist groups trying to get cohousing off the ground, structure could be created that way.

Lynn Pfeffer: If a physical model of a cohousing building were designed for a group of 20-25 units for seniors, incorporating a communal space - and the design had been used successfully in several other buildings - would a developer look at that?

David Kardish: It would depend on how busy we are with other things. This year I had no time for something like this. It's been a very good year, and we have to chase the market when it's good. If business were slow, it may be something we'd look at. I'll give you a prime example of this: Bill Malhotra, who owns Claridge homes, started by building a lot of non-profit housing during the recession in the 90's, and he made his first money in that sector. He wanted to be developing, but there weren't many opportunities because the market was depressed. The 
government was moving forward with non-profit housing to stimulate the economy. In those types of markets, developers have more time, and they may seek out things to keep their staff busy, because we all have overhead. But in busy times, we may not chase these 25-unit projects. We're chasing the 100-unit projects, because we want to maximize our return.

Lynn Pfeffer: Thank you for all your insights and for contributing your valuable time to participate in this interview.

David Kardish: My pleasure. Good luck. 